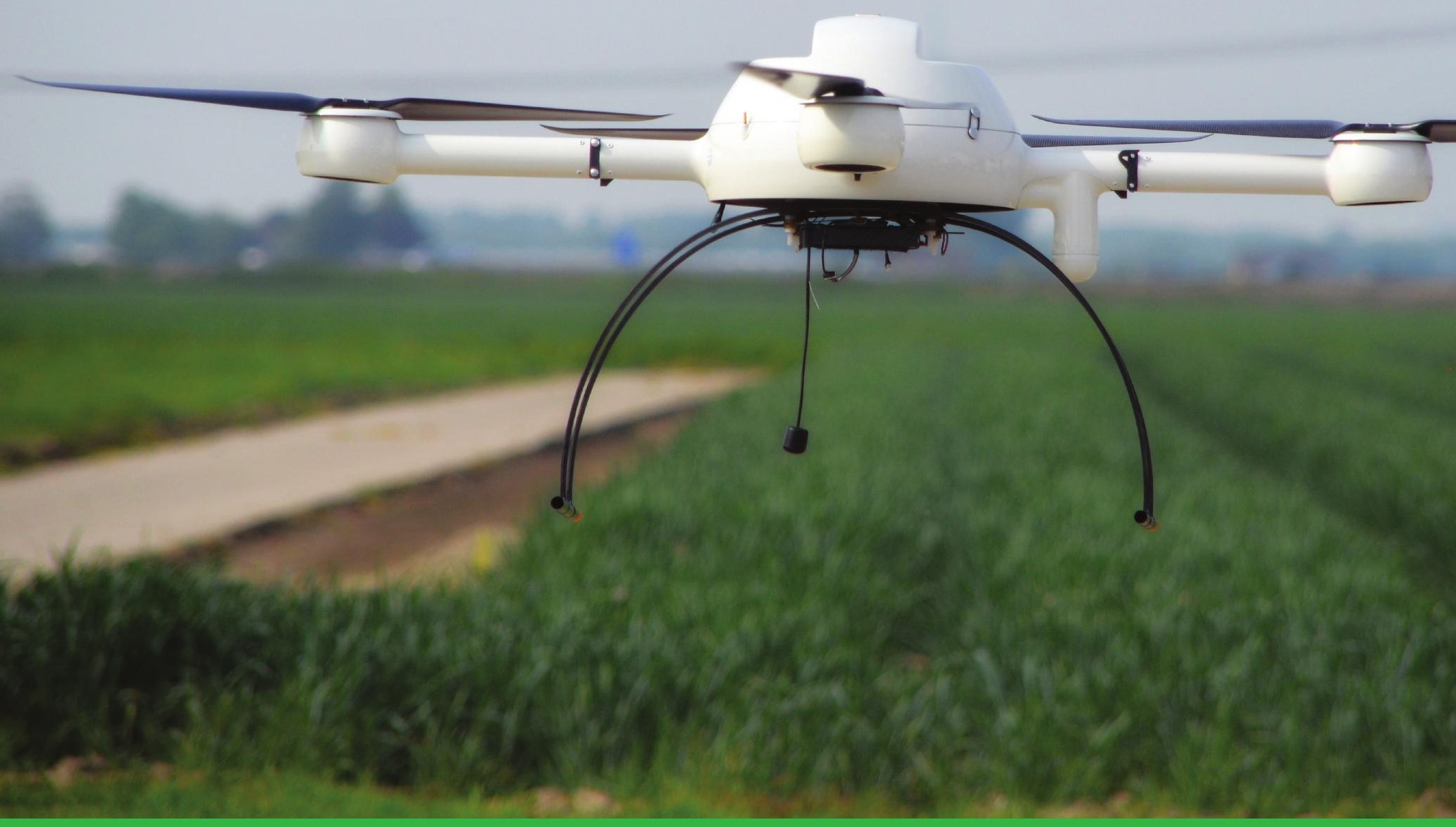

\title{
Een verkenning naar toepassing van drones in landbouw en natuur
}

Drijfveren, kansen en consequenties

Tamme van der Wal, Marcel Meijer en Frans I. Rip

WAGENINGEN

UNIVERSITY \& RESEARCH 



\section{Een verkenning naar toepassing van drones in landbouw en natuur}

Drijfveren, kansen en consequenties

Tamme van der Wal, Marcel Meijer en Frans I. Rip

Dit onderzoek is uitgevoerd door Alterra Wageningen UR in opdracht van en gefinancierd door het ministerie van Economische Zaken, in het kader van het Beleidsondersteunend onderzoekthema 'Duurzame plantaardige ketens' (projectnummer BO-20-003).

Wageningen Environmental Research (voorheen Alterra)

Wageningen, augustus 2016

Rapport 2742

ISSN 1566-7197 
Wal, T. van der, M. Meijer en F.I. Rip, 2016. Een verkenning naar toepassing van drones in landbouw en natuur; Drijfveren, kansen en consequenties. Wageningen, Wageningen Environmental Research, Rapport 2742. 50 blz.; 27 fig.; 0 tab.; 13 ref.

Dit rapport is een nadere uitwerking van het rapport van WODC (Wetenschappelijk Onderzoek- en Documentatie Centrum van het ministerie van Veiligheid en Justitie) uit begin 2015 naar het gebruik van drones. Deze uitwerking, gemaakt in opdracht van het ministerie van Economische Zaken, is gericht op de domeinen landbouw en natuur.

Het rapport begint met een overzicht van de diverse aanduidingen voor drones. Daarnaast wordt de VITAAL-typologie voor drones gepresenteerd. Deze fungeert als raamwerk voor de beschouwing van zes in dit rapport onderscheiden aspecten van drones: Vlucht, Inzetbaarheid, Toepassing, Aansturing, Apparaat en Lading.

In het tweede hoofdstuk zijn de VITAAL-aspecten in verband gebracht met al bestaande en mogelijke toekomstige inzet van civiele drones in landbouw en natuur.

De maatschappelijke vraagstukken die drijfveren (kunnen) zijn voor de inzet van drones komen aan de orde in het derde hoofdstuk, waarbij ook de innovatieopgaven worden besproken die zijn afgeleid uit de maatschappelijke opgaven op het gebied van landbouw en natuur.

Het rapport sluit af met de discussie, gevolgd door conclusies en aanbevelingen voor beleid en nader onderzoek. Deze liggen op het vlak van regeldruk, vergroeningsmaatregelen en verkenning van gevolgen van de inzet van drones in een Living Lab.

This report is an elaboration of an earlier report, prepared in 2015 by WODC, the Research and Documentation Centre of the Dutch Ministry of Security and Justice, about the use of drones. This elaboration, commissioned by the Dutch Ministry of Economic Affairs, focusses on the domains of agriculture and nature.

The report starts with a first chapter about the various names in use for drones. Also, a typology for drones is presented with the acronym VITAAL, which includes 6 aspects of drones: Flight, Employability, Application, Control, Machine and Payload.

In the second chapter the VITAAL-aspects are associated with existing and possible future use of nonmilitary drones in agriculture and nature management.

The social issues that (could) provide motives to employ drones are dealt with in the third chapter. A number of innovation challenges is named, derived from the social issues related to agriculture and nature management.

The final chapters of the report provide a discussion of the subject, followed by conclusions and recommendations for policy and further research. They are about the pressure of rules, greening measures and exploration of the use of drones in a Living Lab.

Trefwoorden: drones, typologie, landbouw, natuur, regeldruk, vergroeningsmaatregelen, Living Lab

Dit rapport is gratis te downloaden van http://dx.doi.org/10.18174/389633 of op

www.wur.nl/environmental-research (ga naar 'Wageningen Environmental Research' in de grijze balk onderaan). Wageningen Environmental Research verstrekt geen gedrukte exemplaren van rapporten.

2016 Wageningen Environmental Research (instituut binnen de rechtspersoon Stichting Wageningen Research), Postbus 47, 6700 AA Wageningen, T 03174807 00, E info.alterra@wur.nl, www.wur.nl/environmental-research. Wageningen Environmental Research is onderdeel van Wageningen University \& Research.

- Overname, verveelvoudiging of openbaarmaking van deze uitgave is toegestaan mits met duidelijke bronvermelding.

- Overname, verveelvoudiging of openbaarmaking is niet toegestaan voor commerciële doeleinden en/of geldelijk gewin.

- Overname, verveelvoudiging of openbaarmaking is niet toegestaan voor die gedeelten van deze uitgave waarvan duidelijk is dat de auteursrechten liggen bij derden en/of zijn voorbehouden.

Wageningen Environmental Research aanvaardt geen aansprakelijkheid voor eventuele schade voortvloeiend uit het gebruik van de resultaten van dit onderzoek of de toepassing van de adviezen.

Wageningen Environmental Research Rapport 2742 | ISSN 1566-7197

Foto omslag: Tamme van der Wal, mei 2016 


\section{Inhoud}

$\begin{array}{ll}\text { Samenvatting } & \mathbf{5}\end{array}$

1

Inleiding $\quad 7$

$\begin{array}{lll}1.1 & \text { Aanleiding } & 7\end{array}$

$\begin{array}{lll}1.2 & \text { Onderzoeksvragen } & 7\end{array}$

$\begin{array}{lll}1.3 & \text { Aanpak } & 7\end{array}$

1.4 Terminologie $\quad 8$

1.5 Drone typologie $\quad 8$

$\begin{array}{lll}1.6 & \text { Opbouw rapport } & 10\end{array}$

$2 \quad$ Civiele drones voor landbouw en natuur

11

2.1 Ontwikkeling en drijfveren van drones - algemeen $\quad 11$

2.2 Stakeholders $\quad 15$

2.2.1 Bedrijfsleven Agrifood 16

2.2.2 Bedrijfsleven Leveranciers 16

2.2.3 Wetenschap 16

2.2.4 Maatschappij 17

$\begin{array}{ll}2.2 .5 \text { Financiers } & 17\end{array}$

2.2.6 Publieke opinie $\quad 18$

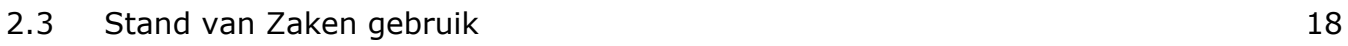

2.3.1 Vlucht 18

2.3.2 Inzetbaarheid 19

$\begin{array}{ll}2.3 .3 \text { Toepassing } & 21\end{array}$

2.4 Stand van Zaken Technologie $\quad 21$

$\begin{array}{ll}2.4 .1 \text { Aansturing } & 23\end{array}$

2.4.2 Apparaat 23

2.4.3 Lading (Payload) $\quad 24$

2.5 Gebruik in de landbouw $\quad 25$

2.5.1 Voorbeelden akkerbouw 25

2.5.2 Voorbeelden in de veehouderij 30

2.5.3 Toepassingen voor handhaving door overheden 30

$\begin{array}{ll}2.5 .4 \text { Indoor } & 31\end{array}$

2.5.5 Adoptiebarrières in de landbouw 32

$\begin{array}{lll}2.6 & \text { Gebruik in de natuur } & 33\end{array}$

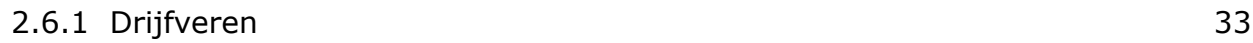

2.6.2 Voorbeelden in de natuur $\quad 34$

$\begin{array}{lll}2.7 & \text { Technologische ontwikkeling } & 35\end{array}$

2.8 Verwachtingen en belemmeringen 36

2.9 Maatschappelijke vraagstukken als (toekomstige) drijfveren 37

3.1 Maatschappelijke vraagstukken als (toekomstige) drijfveren 39

$\begin{array}{ll}3.1 .1 & \text { Duurzame landbouw } \\ 3.1 .2 & 39\end{array}$

$\begin{array}{ll}3.1 .2 \text { Beter natuurbeheer } & 39\end{array}$

$\begin{array}{ll}3.1 .3 \text { Handhaving } & 39\end{array}$

$\begin{array}{ll}3.1 .4 \text { Werkgelegenheid } & 40\end{array}$

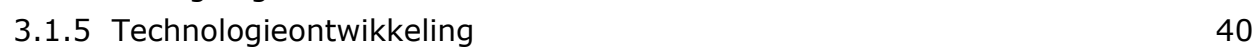

3.1.6 Maatschappelijke issues $\quad 40$

3.2 Maatschappelijke opgaven in innovatieopgaven omgezet 41 
5 Conclusies en aanbevelingen

5.1 Aanbevelingen 


\section{Samenvatting}

In het kader van het technologieproject van de directie Agro en Natuur van het ministerie van Economische Zaken is aan Alterra opdracht verleend om een verkenning uit te voeren naar de toepassingen van drones in landbouw en natuur en daarbij een overzicht te geven van de huidige en toekomstige markt, toepassingen en daaraan gekoppelde maatschappelijke vraagstukken. Deze vraagstelling is vertaald naar een aantal onderzoeksvragen, die zijn beantwoord op basis van studie van literatuur na 2010, huidige wetgeving en jurisprudentie en mede door interviews met ondernemers en belanghebbenden in het veld. De eindtekst is tot stand gekomen in overleg met het ministerie.

Met de term 'drone' wordt een op afstand bestuurd vliegtuigje bedoeld, hoewel er ook andere benamingen worden gebruikt, zoals UAV, UAS of RPAS. Om de breedte en diversiteit van het onderwerp hanteerbaar te maken, is de VITAAL-typologie ontwikkeld, die van drones zowel gebruiksaspecten beschrijft (Vlucht, Inzetbaarheid, Toepassing) als de technologie (Aansturing, Apparaat, Lading).

Aan de hand van VITAAL zijn de stand van de techniek en het actuele gebruik in landbouw en natuur beschreven, die beide volop in ontwikkeling zijn. Daarnaast is aangegeven wat de drijfveren zijn om in deze domeinen tot investering in en gebruik van drones te komen.

Op grond van het voorgaande concludeert dit rapport:

Kansen voor drones in de landbouw:

- de drone als vliegende camera biedt een veelvoud aan innovaties. Voor de landbouw is de meest in het oog springende innovatie om met drones taakkaarten voor precisielandbouw te maken, voor plaatsspecifieke (of plantspeficieke) verzorging van gewassen;

- spuitdrones, als innovatie op de bemande landbouwluchtvaart, is een innovatie die vooral van pas komt bij moeilijk bereikbare akkers en velden, zoals de steile hellingen in de Moezel en de rijstvelden in Japan. Voor Nederland biedt de spuitdrone met name een alternatief voor zware machines door het vermijden van bodemverdichting.

Kansen voor drones in de natuur:

- de monitoringsmogelijkheden uit de landbouw zijn ook in de natuur toepasbaar: verkenning en detectie van bosbranden of stropers dan wel eenvoudigweg voor het tellen van bezoekers;

- maken van natuurfilms.

De belangrijkste maatschappelijke consequenties van de inzet van drones zijn:

- dataprivacy komt onder druk te staan;

- data-gedreven landbouw, die grootschaliger en intensiever zal zijn.

De volgende aanbevelingen worden gedaan:

- dat EZ meer aandacht geeft aan de ontwikkeling van drones als onderdeel van het technologische complex van de precisielandbouw;

- dat EZ een belangrijke tegenkracht gaat vormen binnen de overheid waar het de ontwikkeling van de regelgeving rond gebruik van drones betreft;

- aanmerken van precisielandbouw als vergroeningsmaatregel in het Europese landbouwbeleid, of in eigen land stimulering van precisielandbouw koppelen aan milieu- en klimaatdoelen;

- het aanwijzen en inrichten van een gebied als Living Lab voor de inzet van drones ten behoeve van landbouw en/of natuur;

- verdere verkenning, ook buiten Nederland, van de maatschappelijke consequenties van drones, gekoppeld aan een Living Lab. 


\section{$1 \quad$ Inleiding}

\subsection{Aanleiding}

In 2015 heeft het Wetenschappelijk Onderzoek- en Documentatiecentrum (WODC) van het ministerie van Veiligheid en Justitie een verkennend onderzoek gedaan naar het gebruik van drones (WODC, 2015). Op 2 maart 2015 heeft het kabinet in een brief aan de Tweede Kamer een reactie op dit onderzoek gegeven. Daarbij is aangegeven dat op een aantal domeinen een nadere verkenning zal worden uitgevoerd, onder andere in de landbouw. Deze verkenning is een uitwerking van dat voornemen en is uitgebreid met het natuurdomein.

Deze verkenning is tevens een onderdeel van en dient als casus binnen het technologieproject van de directie Agro en Natuur. Dit project is ten eerste gericht op het (beter) benutten van (nieuwe) technologie voor de maatschappelijke vraagstukken en beleidsdoelen die spelen op het terrein van agro en natuur. Ten tweede is het project gericht op de zorg voor de maatschappelijke inbedding van beloftevolle technologieën gezien de maatschappelijke uitdagingen.

\subsection{Onderzoeksvragen}

De opdracht van deze studie is:

Verken de toepassingen van drones in landbouw en natuur en geef daarbij een overzicht van de huidige en toekomstige markt, toepassingen en daaraan gekoppelde maatschappelijke vraagstukken.

Deze opdracht is concreet vertaald in de volgende vragen en onderwerpen:

1. Wat waren de drijvende krachten van de ontwikkeling van drones tot nu toe?

2. Welke (maatschappelijke) vraagstukken uit de domeinen landbouw of natuur waren onderdeel van deze drijvende krachten?

3. Tot welke stand van zaken heeft dat geleid?

4. Gezien de maatschappelijke uitdagingen (thema's uit innovatieagenda's A\&F, T\&U en HTSM) in diverse sectoren: waar zouden de drones verder nog ingezet kunnen worden?

5. Wat voor maatschappelijke discussies/issues (kunnen) gaan spelen rond de ontwikkeling, maar vooral rond de toepassing van drones in landbouw en natuur, die mogelijk belemmerend gaan werken?

6. Wat is de ontwikkeling in wet- en regelgeving?

Deze vragen zijn in de navolgende hoofdstukken verwerkt.

\subsection{Aanpak}

De onderzoeksvragen zijn in dit rapport beantwoord aan de hand van een deskstudy en interviews. De deskstudy omvat een analyse van wetenschappelijke literatuur, vakliteratuur en mediaberichten met betrekking tot het gebruik van drones. Bovendien zijn, met name voor het juridische kader, de huidige wet- en regelgeving en jurisprudentie met betrekking tot het gebruik van drones geanalyseerd.

Daarbij staat de Nederlandse situatie centraal, maar wordt er ook verwezen naar voorbeelden uit andere landen.

Wat betreft de mogelijke toepassingen van drones in de context van landbouw en natuur is ruimer gekeken. En hebben we ons met name gericht op publicaties na 2010. Het betreft hier zowel wetenschappelijke publicaties als artikelen uit de vakliteratuur.

Voor deze verkenning zijn enkele interviews gehouden met:

- Bert Rijk en Philippe Serruys van Aurea Imaging ondernemers en pioniers in de toepassing van drones in de landbouw;

- Monique Wordragen van Airinov - ondernemer in de toepassing van drones in de landbouw; 
- Winfried Rijssenbeek van Drone4agro - ondernemer en dronebouwer/ontwikkelaar;

- Thomas van der Es van Staatsbosbeheer - Boswachter van Nationaal Park de Biesbosch;

- Geert Munnichs van het Rathenau Instituut - onderzoeker ICT, veiligheid en privacy. Het rapport is tot stand gekomen in opdracht van, en in interactie met, Gertjan Fonk van het ministerie van Economische Zaken, en een EZ-klankbordgroep.

\subsection{Terminologie}

Voor onbemande luchtvaartuigen zijn er verschillende termen in omloop. De bekendste en verreweg meest gebruikte term is 'drone', die echter in eerste instantie vooral militair en tegenwoordig ook vooral voor consumentenartikelen gebruikt wordt. In wetenschappelijke literatuur wordt vooral de term Unmanned Aerial Vehicle (UAV) gebruikt, terwijl in andere domeinen ook de term Unmanned Aircraft System (UAS) gebruikt wordt. In de luchtvaart spreekt men voor de algemenere betekenis conform de regels van de Internationale Burgerluchtvaartorganisatie (ICAO) over Remotely Piloted Aircraft System (RPAS), omdat de luchtvaartwet een belangrijke rol aan de piloot toedicht ("There is nothing unmanned about a $U A V^{\prime \prime}$ ). Dit gaat echter voorbij aan de tendens van toenemende autonomie van drones, zowel in de lucht als bij opstijgen en landen.

De formele definitie die in (Europese) regelgeving wordt gehanteerd, is Unmanned Aircraft:

'Unmanned aircraft' means any aircraft operated or designed to be operated without a pilot on board. (EASA, 2015a).

De term 'drone' is inmiddels behoorlijk ingeburgerd. Om het onderscheid met militair materieel te maken, wordt ook vaak gesproken van een civiele drone. De Europese Airspace Safety Agency (EASA) spreekt van drones om zowel de op-afstand-bestuurde en de autonome drones te omvatten (EASA, 2015b). Ter geruststelling voor de achterban stelt EASA dat: "It should be noted that this concept [drones, red.] in most of its paragraphs - except in the outlook paragraph - assumes drones to be remotely piloted and with no people on board."

Voor de leesbaarheid van dit rapport zullen wij in overeenstemming met de EASA de term drone hanteren.

\subsection{Drone typologie}

Het domein van drones is enorm breed en divers. Het biedt daarom houvast om een goede typologie te hebben naast een heldere definitie. Een typologie wordt vaak als 'stamboom' neergezet waarin de ontwikkeling geschetst wordt vanuit een startpunt. De huidige ontwikkeling van drones kent twee oorsprongen, een militaire en een recreatieve. Maar deze twee oorsprongen bieden onvoldoende houvast om de huidige stand van zaken te typeren, waarbij naast militair en recreatief ook de civielcommerciële sector zich stormachtig ontwikkelt.

Om de verschillende ontwikkelingen rondom drones te structureren en te kunnen duiden, wordt in dit onderzoek gebruikgemaakt van een drone typologieraamwerk, genaamd VITAAL (Figuur 1). Dit is een acroniem van de zes hier onderscheiden droneaspecten: Vlucht, Inzetbaarheid, Toepassing, Aansturing, Apparaat, Lading. Dit brengt de verschillende aspecten rond het gebruik van drones op een overzichtelijke wijze in beeld. Het helpt om het gebruik van drones in een bredere context te plaatsen van ontwikkelingen binnen landbouw en natuur. Ook kan aan de hand van dit raamwerk aangegeven worden welke onderdelen nog onderontwikkeld zijn dan wel extra aandacht behoeven.

1 Uitspraak van de UAVSI tijdens een public hearing in het Amerikaanse congres in 2013. 


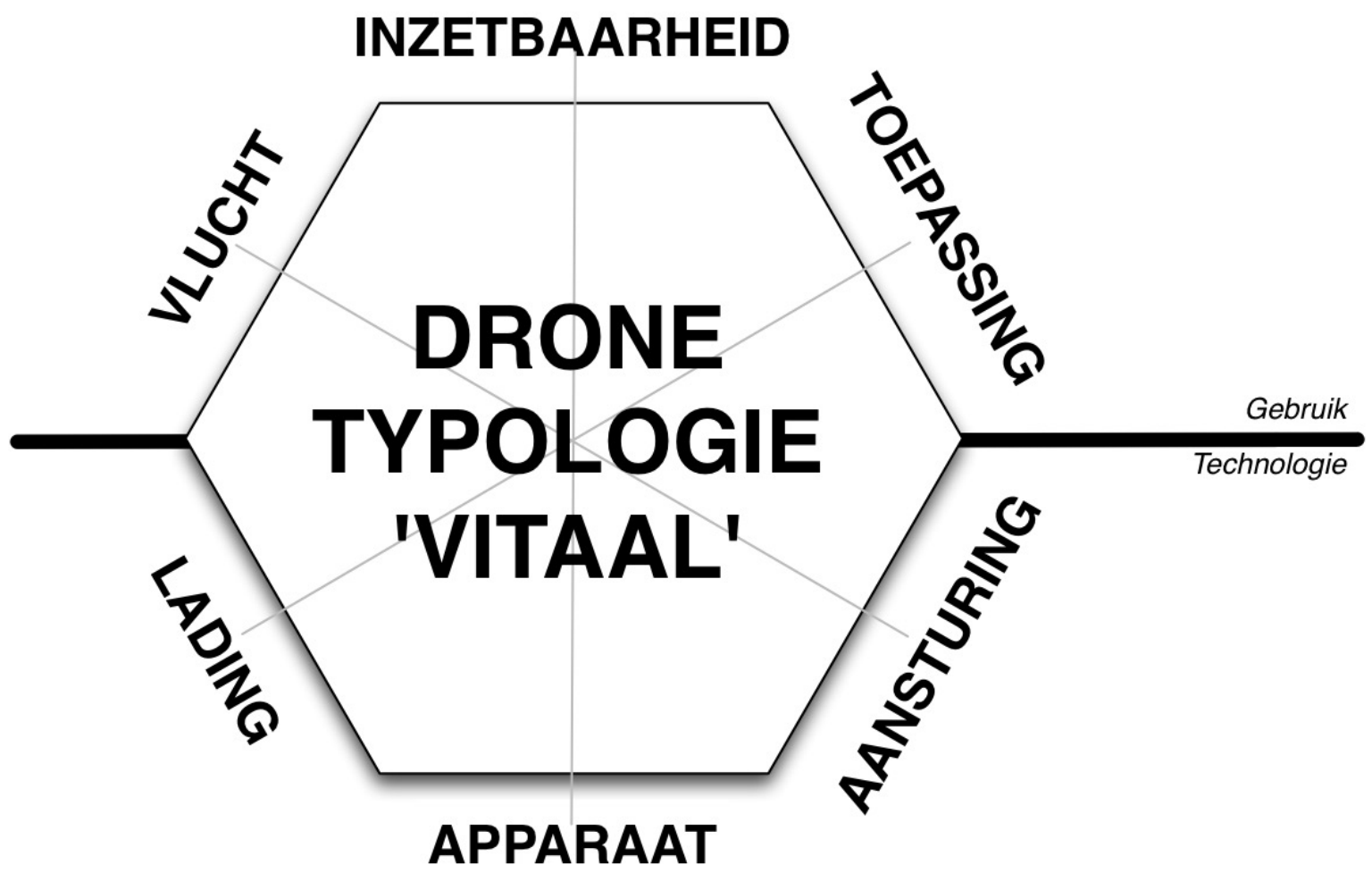

Figuur 1 Drone typologieraamwerk.

Op basis van analyse en clustering van bestaande dronekenmerken kan er een onderscheid gemaakt worden in drie technologieaspecten en drie gebruiksaspecten:

\section{GEBRUIK:}

Vlucht:

Inzetbaarheid:

Toepassing:
Het uitvoeren van vluchten (de 'operation') omvat het deel van voorbereiding, opstijgen, uitvoeren van de missie en het landen. Informatie over een (aanstaande) vlucht wordt gemeld via de zgn. Notice to Airmen (NOTAM), waarmee andere luchtgebruikers geïnformeerd worden. Er wordt bijvoorbeeld onderscheid gemaakt in verschillende risico-categorieën (laag, midden, hoog) en onderscheid in zichtvluchten (in Visual Line of Sight) en Beyond Visual Line of Sight. In Europa is regelgeving in voorbereiding waarbij de vlucht centraal staat. De regelgeving wordt daarmee gericht op performance en operationeel risico.

De inzetbaarheid van drones omvat het geheel aan maatregelen die men moet treffen om ook daadwerkelijk te vliegen. Een deel van de maatregelen betreft het voldoen aan wet- en regelgeving, zoals brevetten, vergunningen en certificaten. Daarnaast zijn er aanvullende omstandigheden, zoals meteorologie, gebiedsbeperkingen (bv. andere luchtvaart, bebouwing) etc. En de piloot moet toestemming hebben van de eigenaar voor het opstijgen vanaf en landen op een locatie.

Dit is het doel waarvoor een drone wordt ingezet. Het is in feite een concrete taak of activiteit, waarbij een passende payload hoort: kartering is een andere toepassing dan gewasbescherming. De lijst van toepassingen is schier onuitputtelijk, maar de belangrijkste drie toepassingsgebieden zijn kartering (drone als platform voor camera's en sensoren), transport (drone als vliegend transportmiddel) en ingrepen (drone als drager van apparaten voor specifieke taken). 
TECHNOLOGIE:

Apparaat:

Aansturing:

Lading:
Het Unmanned Aircraft System gaat primair over de drone zelf als apparaat. Er wordt vaak onderscheid gemaakt in zgn. 'fixed wings' tegenover 'Rotorcrafts', zoals de helikopter en multirotors (Quadcopter/Hexacopter/Octocopter etc.). Ook de wijze van opstijgen en landen wordt als onderdeel van het apparaat gezien, waarbij het kan gaan om katapulten of vangnetten.

Er zijn volledig autonome drones en er zijn volledig op afstand bestuurde drones. Vaak bestaat de aansturing van drones uit een combinatie van autonomie-modi, bv. handmatig opstijgen en landen, en tussendoor overschakelen op autopilot. De afstandsbediening is via een radiolink met het apparaat verbonden. Er zijn ook besturingsondersteunende systemen, zoals een zgn. Sense \& Avoid-systeem om in autonome vluchten botsingen te voorkomen, een geo-fencing systeem om toegang tot zgn. no-flyzones te voorkomen of een transponder om de drone en locatie te delen met andere luchtruimgebruikers.

De lading, of Payload, is dat deel van de drone waarmee het inzetdoel wordt gerealiseerd, zoals een camerasysteem (voor teledetectie van gewascondities), een sproei-installatie (voor toediening van meststoffen of gewasbeschermingsmiddelen) of het transport van cargo (inclusief mensen).

Dit Drone-VITAAL-raamwerk helpt bij het begrijpen en plaatsen van drones en het duiden van aspecten die te maken hebben met technologie en gebruik. Er kan mee aangegeven worden waar onderscheid relevant is. Het biedt ook houvast in de bespreking van het onderwerp. Het raamwerk vormt de basis voor de 'stand der technologie' en de 'stand van het gebruik' in hoofdstuk 2.

\subsection{Opbouw rapport}

In hoofdstuk 2 worden de drijfveren beschreven vanuit de landbouw en natuur van waaruit interesse en investeringen in drones ontstaan. Het geeft een overzicht van stakeholders en voorbeelden van toepassingen.

Hoofdstuk 3 beschrijft de beleidsaspecten die van belang zijn bij deze ontwikkeling.

Hoofdstuk 4 bevat de discussie.

Hoofdstuk 5 geeft de conclusies en aanbevelingen die volgen uit deze verkenning. 


\section{Civiele drones voor landbouw en natuur}

Dit hoofdstuk beschrijft de drijfveren vanuit de landbouw en het natuurbelang om in de toepassing van drones te investeren. Er wordt een overzicht van spelers, toepassingen en adoptiebarrières gegeven. Dit hoofdstuk wordt afgesloten met een bespiegeling van de consequenties van brede inzet van drones in de landbouw en natuur.

\subsection{Ontwikkeling en drijfveren van drones - algemeen}

De huidige ontwikkeling van drones kent eigenlijk twee oorsprongen. De eerste is de militaire oorsprong; drones werden oorspronkelijk ingezet als bestuurde bommen of vliegende doelen voor schietoefeningen. De naam Drone is een afgeleide of hommage aan de Queen Bee, een op afstand bestuurd vliegtuig als oefendoel (Wall Street Journal, 2013). Dit heeft zich ontwikkeld tot herbruikbare, onbemande gevechts- en verkenningstoestellen. De drijfveren daarvoor waren de behoefte aan hogere veiligheid door betere surveillance en situational awareness te genereren enerzijds, en anderzijds om effectievere en preciezere aanvalskracht te ontwikkelen zonder eigen militairen op de grond en dus minder eigen slachtoffers. De militaire ontwikkeling en toepassing van drones is veruit de belangrijkste motor geweest tot nu toe.

Een tweede oorsprong is het recreatief gebruik van modelvliegtuigen. De geminiaturiseerde technologie werd al jaren op civiele wijze ingezet door modelbouw-enthousiasten. Zij zijn meestal verenigd in clubs die met schaalmodellen vliegen en demonstraties of wedstrijden houden op speciaal daarvoor toegewezen locaties. De beperkte beschikbaarheid en betaalbaarheid van componenten maakte dat dit jarenlang een specialistische hobby is geweest. Verdergaande miniaturisering en integratie van allerlei ICT-technologieën (zoals streaming realtime video, betere accu's (langere vliegduur per gram) en allerlei microsensoren) hebben echter bijgedragen aan de ontwikkeling van een totaal nieuwe racesport voor recreatieve drones. De camerabeelden stellen de piloot in staat zich coureur te voelen.

Inmiddels worden drones naast militaire en recreatieve toepassingen ook steeds meer ingezet in de civiel-commerciële toepassingen. Dit is een domein dat zich stormachtig ontwikkelt. Ondernemers zien legio kansen, met name omdat activiteiten met de drone beter of eenvoudiger kunnen (en dus meer value for money bieden dan bestaande alternatieven). Dit geldt bijvoorbeeld voor de televisie- en filmindustrie (het Belgische FlyingCam heeft zelfs al twee Oscars gewonnen met hun door een drone gedragen camera) waar spectaculairdere shots gemaakt kunnen worden. Ook voor de luchtfotografie en logistiek (pakketbezorging) is vergroting van efficiëntie makkelijk voorstelbaar. Andere ondernemers stappen in een nieuwe dienstverlening zoals in de landbouw en natuurdomeinen. De meest in het oog springende toepassing is hier de Remote Sensing of teledetectie, oftewel het op afstand waarnemen. Dit was tot nu toe voorbehouden aan satellieten en bemande vliegtuigen. Dronediensten maken deze techniek bereikbaar voor individuele boeren en natuurbeheerders, door de kleinere en behapbare schaal, de flexibiliteit en het daadwerkelijke zicht op de opname. Daarmee draagt de drone enorm bij aan precisielandbouw. De doelen hierachter, of drijfveren, zijn het realiseren van een rendabele en verantwoorde landbouw. Een voorbeeld daarvan is dat het gebruik van kunstmest beter wordt afgestemd op de behoefte van het gewas (de zgn. variabele of plaatsspecifieke dosering). Ten opzichte van de gangbare uniforme kunstmestgift levert plaats-specifieke dosering een besparing van kunstmest, wat een gunstig effect heeft op de kosten en bovendien bijdraagt aan vermindering van de emissies van nutriënten (zowel naar grondwater als naar atmosfeer).

De ontwikkeling van drones is dus primair gedreven vanuit de defensie-industrie: behoefte aan permanente surveillance van crisiszones en tevens aan onbemande gevechtscapaciteit waren en zijn nog steeds belangrijke drijfveren. Met de verbreding van toepassingen in de civiele sector zijn tal van nieuwe mogelijkheden denkbaar geworden. 


\section{Vraagsturing}

In tegenstelling tot sommige andere innovaties is in de landbouw de vraagsturing ten aanzien van drones vooral vanuit dienstverleners (o.a. adviseurs, coöperaties, loonwerkers) gekomen. Deze dienstverleners zien kansen en mogelijkheden om met drones een aantrekkelijkere aanbieding te doen. Dit hangt samen met een algemeen model van drijfveren van bedrijven voor het commercialiseren van technologische innovaties. Die zijn als volgt ondergebracht in drie fasen (naar o.a. Gaddis, 2014):

1. Vereenvoudiging/toegankelijkheid van reeds bestaande mogelijkheden: de innovatieve technologie, in dit geval de drone, maakt het efficiënter of eenvoudiger en bereikbaar voor meer mensen en bedrijven om bepaalde activiteiten uit te voeren.

2. Nieuwe dienstverlening en businessmodellen: start-ups en bestaande dienstverleners grijpen de drone aan om nieuwe services neer te zetten en daarmee een nieuwe markt te ontwikkelen of zich te onderscheiden van andere dienstverleners. Deze nieuwe diensten zullen zich moeten bewijzen, maar kunnen vooral zinvol zijn als goedkopere of betere alternatieven.

3. Grootschalige aanschaf: de wisselwerking tussen productie en vraag zorgt dat de prijs van drones zodanig daalt dat iedereen er uiteindelijk een wil hebben en kan betalen. Het gaat hierbij niet om alle mogelijke toevoegingen en functionaliteiten, maar vooral om gebruiksgemak, robuustheid en betaalbaarheid.

Een aantal dienstverleners heeft het oog op de toepassing van drones in de landbouw laten vallen. Met name het gebruik van camerasystemen is interessant, voor het genereren van data voor precisielandbouw en om daarmee efficiënter te produceren. Pioniersbedrijf Aurea Imaging uit België (dat vanwege regelgeving veel in Nederland werkt) heeft als een van de eersten de mogelijkheden van drones gezien als alternatief voor satellietdata en dat in een operationele dienst vertaald. Anderen, zoals agronomisch adviesbureau Delphy en coöperaties als Agrifirm en CZAV, onderzoeken mogelijkheden om de dienstverlening aan boeren met dronebeelden te verbeteren, met name als ondersteuning van de precisielandbouw. Het van oorsprong Franse bedrijf Airinov speelt hier ook op in en levert kant-en-klare instructies voor plaats-specifieke bemesting of gewasbescherming gebaseerd op dronebeelden. Dienstverleners voor Remote Sensing-data voor de landbouw komen typisch uit twee verschillende hoeken: het zijn technologiebedrijven die in een aantal sectoren actief zijn waaronder landbouw - of het zijn landbouwdienstverleners (zoals adviseurs, coöperaties of loonwerkers) die hun dienstenpakket hiermee uitbreiden.

Voor de landbouw is de vereenvoudiging en de toegankelijkheid van Remote Sensing van belang. Van boeren (net als andere beheerders van land, zoals boswachters) kun je zeggen dat ze altijd behoefte hebben aan actuele informatie over de door hen beheerde terreinen. Luchtfotografie maakt dit mogelijk. In eerste instantie waren het dienstverleners, niet de boeren en terreinbeheerders, die de mogelijkheden van luchtfotografie en drones inzagen en het als nieuwe technologie oppakten om die behoeftes in te vullen. Nadat zij op een eenvoudigere wijze beeldmateriaal konden verzamelen, zijn de mogelijkheden voor klanten in beeld gebracht: hogere nauwkeurigheid van de informatie, vliegen wanneer men wil en een duidelijke een-op-eenrelatie met de leverancier. Zo zijn er nieuwe diensten in de markt gezet om boeren te voorzien van actuele beelden of kaarten van de stand van het gewas. Daarnaast zijn er ook andere, nieuwe diensten en toepassingen ontstaan (zie ook de voorbeelden hieronder).

\section{Precisielandbouw}

Drones zijn voor de landbouw, en dan met name de precisielandbouw, zeer interessant. Dat komt doordat de landbouw altijd op zoek is naar mogelijkheden om met zo weinig mogelijk middelen een zo hoog mogelijke opbrengst te genereren. Omdat precisielandbouw ook op het gebied van milieu (minder vervuiling van lucht en water) en economie winst oplevert, ondersteunt de overheid deze ontwikkelingen. Individuele en collectieve belangen vallen hier dus voor een groot deel samen. Precisielandbouw, oftewel de toediening van de juiste dosering van het juiste middel op de juiste plek en het juiste tijdstip, vergt plaats-specifieke informatie op basis waarvan de dosering en timing van middelen wordt vastgesteld. In de precisielandbouw is er dus behoefte aan data over de verschillende groeiplaatsen en binnen het gewas. Deze informatie wordt onder andere door Remote Sensing geleverd.

Satellietbeelden zijn jarenlang de belangrijkste bron geweest voor de landbouw, omdat de luchtfotografie duur en onvoldoende georganiseerd was voor dienstverlening in de landbouw. De 
ontwikkeling van drones, simultaan aan de ontwikkeling van geavanceerde en geminiaturiseerde camera's, heeft tot veel innovaties op dit gebied geleid. Vele dronefabrikanten geven aan dat hun drone geschikt is voor landbouw of zelfs speciaal daarvoor ontwikkeld is (AgEagle, PrecisionHawk, Parrot / SenseFly, Aerialtronics, DJY e.a.).

\section{Korte keten}

Het grote voordeel van drones ten opzichte van satellieten of bemande luchtvaart is de grotere flexibiliteit en verkorte keten tussen "fotograaf" en gebruiker. De dronepiloot/cameraman komt bij de boer op het bedrijf. De data worden ter plaatse verwerkt of anders de volgende dag toegestuurd. Dit is een heel andere benadering dan de satellietbeelddiensten waarbij de afstand tussen degene die de opnames afwerkt en de boer verhoudingsgewijs lang is en er een keten is ontstaan met meerdere tussenpersonen. Ook met luchtfotografie is de keten tussen opname en gebruik lang. De flexibiliteit of slagvaardigheid van drones is bovendien groter, zodat bijvoorbeeld sneller op een 'gunstige' weersituatie voor luchtfotografie ingespeeld kan worden.

Diverse loonwerkers hebben hun dienstverlening inmiddels verbreed met dronevluchten en -opnames. Maar er zijn ook boeren die zelf een drone (willen) aanschaffen om te experimenteren en zelf te vliegen wanneer zij dat nodig vinden. Behalve precisielandbouwtoepassingen zijn boeren ook nieuwsgierig naar de toestand van hun gewas en ook opnames met eenvoudige fotocamera's bieden al mogelijkheden voor geavanceerde crop-scouting.

\section{Toegang tot moeilijk bereikbare gebieden en bodembescherming}

Een andere drijfveer vindt haar oorsprong in Japan. Daar worden op afstand bestuurbare, onbemande helikopters gebruikt voor bespuitingen van natte rijstvelden. Deze velden zijn lastig te bereiken voor landbouwmachines en bovendien lastig te bewerken vanwege de natte bodems. De onbemande helikopters met spuit zijn daar een aantrekkelijk alternatief voor bijvoorbeeld een bemande helikopter of een persoon met een op de rug gedragen sproeier die door de velden moet waden. In Japan zijn er ruim 2000 in gebruik. Die hebben inmiddels ook de aandacht in Europa getrokken: in Duitsland wordt gekeken naar de inzet van onbemande spuithelikopters voor wijngaarden op steile hellingen, zoals in het Moezelgebied (Proplanta, 2015).

In Nederland wordt het voordeel van een 'vliegende spuit' met name verwacht in minder bodemverdichting of structuurbederf door zware wielen. Het kan derhalve een verbetering van de bodemstructuur opleveren en dus hogere opbrengsten. Behalve een spuit kan een drone uiteindelijk ook andere dispensers (bv. voor zaaien) of zelfs andere werktuigen dragen. De drone wordt dan een vliegende tractor. Activiteiten als bestuiven, snoeien, oogsten en wieden kunnen dan allemaal zonder bodemcontact verricht worden waardoor de bodem gezonder en vruchtbaarder blijft. Naast de wet- en regelgeving rondom het veilig gebruik van drones is bij deze toepassingen ook de milieuwetgeving relevant: de spuit mag niet te veel drift (verwaaiing) veroorzaken waardoor bijvoorbeeld bestrijdingsmiddel op de verkeerde plekken zou neerkomen.

Zo wordt er een drone ontwikkeld door Drone4agro, een bedrijf dat zich vooral op het vliegend werkpaard richt: een drone die zo'n $100 \mathrm{~kg}$ aan lading (apparatuur) kan brengen waar het zijn moet, met name voor plaats-specifieke bespuitingen of gerobotiseerde handelingen (snoeien, zaaien etc.). De drijfveer van Drone4agro zit vooral in het vermijden van bodemverdichting met landbouwmachines en een grotere efficiëntie per capita op het landbouwbedrijf.

Ook in natuurgebieden is toegankelijkheid soms lastig, bijvoorbeeld voor het tellen van nesten in een lepelaarskolonie, aldus boswachter Van der Es van de Biesbosch. Natuurlijk levert nesten tellen met een camera onder een drone ook verstoring op. Het is waarschijnlijk echter minder dan een inventariserende boswachter met een bootje.

\section{Toekomstverwachtingen drones in de landbouw}

De marktverwachtingen voor drones in de landbouw zijn hooggespannen, getuige de vele marktrapporten waarin landbouw steevast als potentiële groeimarkt wordt genoemd. De verwachting is dat ook de derde fase, de grootschalige aanschaf, een feit gaat worden. Dit geeft ook een extra impuls aan bedrijven, inclusief start-ups, om hierin te investeren. Figuur 2 geeft een veelvuldig hergebruikte figuur weer over de markt van drones in diverse sectoren, waarbij landbouw de bulk aan droneverkopen laat zien. 
Figure 2: Annual UAS Sales for Agriculture, Public Safety, and Other Markets

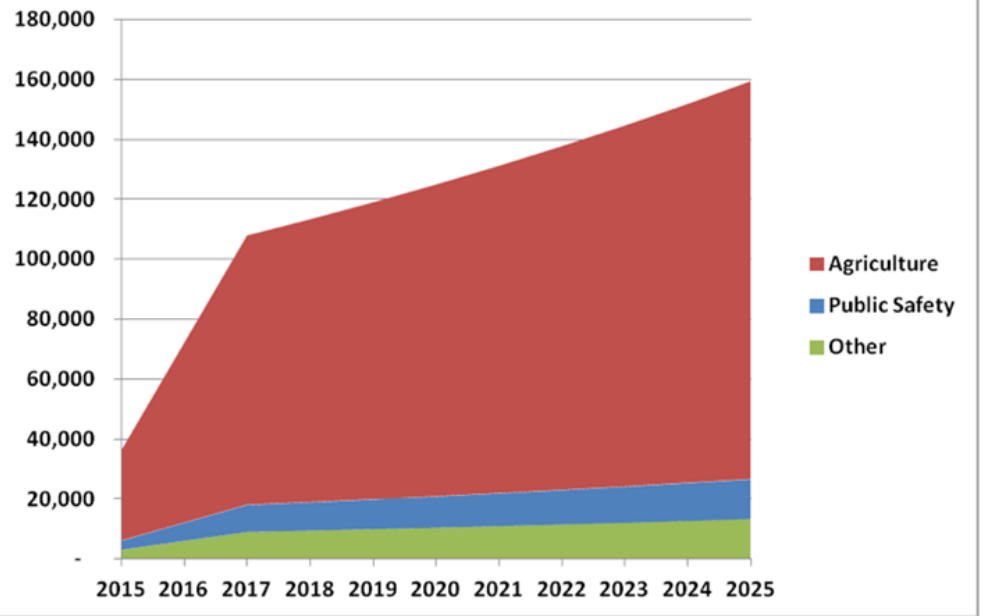

Figuur 2 Marktverwachtingen van drones in verschillende sectoren in aantallen drones per jaar (UAVSI, 2013).

Figuur 2 laat zien dat er een groot potentieel is voor het aantal drones dat met name in de agrarische markt geabsorbeerd kan worden. De economische waarde van die drones bij elkaar zal hoogstwaarschijnlijk vergelijkbaar zijn met de economische waarde in bv. defensie, doordat de landbouw met andere, naar alle waarschijnlijkheid goedkopere, modellen zal werken. Desalniettemin geeft het aan dat landbouw een zeer belangrijke markt vormt voor droneontwikkelaars.

De reden waarom landbouw voor drones zo'n belangrijke markt is, blijft echter in deze rapporten onderbelicht. En er zijn heel veel boeren, dus wanneer die allen een drone aanschaffen, dan heeft dat een enorm potentieel. Hiermee is nog geen uitspraak gedaan over de 'businesscase' van de landbouw. Er wordt doorgaans verwezen naar precisielandbouw en drones worden als een soort 'missing link' gezien. Maar wat is die 'missing link' dan precies?

De precisielandbouw heeft als doel de juiste behandeling te geven, liefst op het niveau van de individuele plant. Dit wordt doorgaans geformuleerd als: "Doing the right thing at the right time and in the right place". Er is een enorme ontwikkeling gaande in de landbouwmechanisatie, waar elektrificatie en robotisering zorgen voor zeer geavanceerde tractors en werktuigen. Met name in de variabele doseringstechnologie heeft een enorme doorbraak plaatsgevonden met computergestuurde spuiten en strooiers. De echte missing link is daarbij dat de benodigde data om deze precisielandbouw uit te voeren onvoldoende aanwezig zijn. De plaats-specifieke technologie in de landbouw vereist invoergegevens over de verschillen in het gewas. In de Australische en Noord-Amerikaanse landbouw wordt daar veelal een bodemkaart of de oogstkaart van voorgaand seizoen voor gebruikt. Daarmee stuurt men op verschillen die structureel en meerjarig van aard zijn. In de Nederlandse situatie wil men daarnaast bovendien op kleinere verschillen sturen. Het gebruik van dierlijke mest, waarbij de toegediende mest van plek tot plek verschilt in samenstelling, in combinatie met bodem, weer en bewerkingen, geeft verschillende beschikbaarheid van nutriënten en dat kan van moment tot moment en van plek tot plek nogal verschillen.

Met speciale camera's kunnen deze verschillen actueel in kaart gebracht worden. Actuele en relevante data worden onder andere ingewonnen met satellieten en bemande fotovluchten. Maar satellieten bieden doorgaans weinig garanties op beelden, vooral door de uitbundige bewolking tijdens een groeiseizoen. De fotovluchten met bemande vliegtuigen zijn duur en vergen veel planning. Beide worden daarom nog weinig toegepast. Voor precisielandbouw hebben satellieten nog (te) weinig betekend, met name omdat de eisen die vanuit precisielandbouw gesteld worden (frequente opnames, hoge resolutie) onvoldoende door satellieten ingevuld worden, niet in de laatste plaats doordat bewolking te vaak het zicht op de aarde vanuit de ruimte verhindert. Er is veertig jaar aan onderzoeksresultaten beschikbaar over wat Remote Sensing voor landbouw kan betekenen, wat nog niet of nauwelijks in concrete diensten voor de boer is omgezet. De verwachting is dat drones een aantrekkelijk alternatief vormen voor satellieten en een belangrijke rol kunnen spelen in het leveren van Remote Sensing-diensten. Het voorbeeld van een aantal innovatieve akkerbouwers in de Hoeksche Waard illustreert dat (Lerink, 2015). 


\section{Ook overheid ziet kansen}

De Nederlandse overheid stimuleert precisielandbouw met wetenschappelijk en toegepast onderzoek en met subsidies op de aanschaf van precisieapparatuur. Dit wordt primair vanuit economische motieven gestimuleerd: kostenbesparingen en kwaliteitsverhoging van de landbouwproductie. Steeds meer komen daar ook andere doelen bij die met deze ontwikkeling sporen. Zo biedt de inzet van drones bijvoorbeeld een kostenbesparing op voor gewasbeschermingsmiddelen en tevens een kleinere kans op emissies naar het milieu. Maatschappelijke doelen en economische doelen vallen zo samen. De Europese organisatie van landbouwmachinefabrikanten, de CEMA, promoot ook juist die milieu- en klimaatdoelen van nieuwere precisietechnieken in de landbouwmachines. Ook hier gaan economie en ecologie hand in hand: elektromotoren zorgen voor lager dieselverbruik, precisietechnologie zorgt voor minder meststoffen en bestrijdingsmiddelen en automatisering faciliteert digitale registratie en daarmee een betere (en meer waterdichte) verantwoording. Het Europees parlement en de Europese Commissie zijn inmiddels ook meer geïnteresseerd in de bijdragen van precisielandbouw aan het realiseren van milieu- en klimaatdoelen.

De inzet van precisielandbouw - of tegenwoordig in een breder kader geplaatst als Smart Farming kan een belangrijke bijdrage leveren aan een duurzame landbouw. Hiermee verdient deze technologische sprong de aandacht van overheid en maatschappij. De landbouw kan er rendabeler, schoner en verantwoorder mee worden. Boeren kunnen verder ook inspelen op de toenemende druk op landbouw om met minder middelen meer te produceren. Klimaatsverandering veroorzaakt meer weersextremen, met name droogte en wateroverlast. Ook hier biedt precisielandbouw mogelijkheden om daarmee om te gaan.

Zoals gesteld gaat de opkomst van precisielandbouw gepaard met een toenemende vraag naar actuele informatie over bodem en gewas. Drones bieden een tot nu toe onbenutte mogelijkheid om efficiënt het gewas in kaart te brengen. Drones zijn daarmee wellicht de missing link die het breder gebruik van de precisielandbouw mogelijk maakt en daarmee maatschappelijke doelen helpt realiseren.

\subsection{Stakeholders}

De toepassing van drones in de landbouw raakt primair aan de precisielandbouw. De landbouw bestaat voornamelijk uit het mkb, zowel in de primaire productie als in de verwerking en toelevering. De sector als geheel heeft daardoor weinig slagkracht in de innovatie, alhoewel landbouw wel een innovatieve sector is. De dienstverleners rondom de landbouw, zoals onderzoek, advies en toelevering verkennen de mogelijkheden van drones in allerlei pilots. Met name organisaties voor onderzoek en/of onderwijs (in Nederland o.a. Wageningen Universiteit, DLO \{Alterra, ASG, PRI en PPO\}, NLR, UT, TU Delft, HAS, CAH Vilentum e.a.) zijn nu actief in het verkrijgen en verwerken van dronebeelden. Maar ook adviseurs (o.a. Delphy), loonwerkers (o.a. Thyssen, Van den Borne) en toeleveringsbedrijven (o.a. Agrifirm, CZAV) zijn er mee bezig. Specialistische dienstverleners als Aurea Imaging, Skyvision, Airinov, DroneWatch e.a. zijn actief in de landbouw en leveren diensten aan boeren en andere spelers. Op dit moment is het aantal hectares waarop drones wordt ingezet echter nog relatief laag. Dit betekent dat deze dienstverlening nog niet volledig is ingeburgerd. Ook is er een aantal boeren dat drones aanschaft voor hun eigen interesse en onderzoek naar wat er kan en niet kan.

In het Europese FP7-project UNIFARM (www.project-unifarm.eu) is een stakeholderanalyse uitgevoerd naar precisielandbouw, wat geresulteerd heeft in een schematische weergave van de omgeving van de boer (Figuur 3) (Van der Wal et al., 2014). Ook de interacties tussen partijen is hier weergegeven. De boer is en blijft natuurlijk de belangrijkste partij. In zijn beslissingen weegt hij zijn voorkeuren in de inzet van bedrijfsmiddelen af. Hij neemt hierin de mogelijkheden mee die industrie en wetenschap schetsen en de randvoorwaarden die de maatschappij en zijn afnemers stellen. Ook de rol van adviseurs is belangrijk. Zij helpen de boer (soms vanuit onafhankelijke positie) in zijn keuze. Het effect van zijn keuzes en strategieën leidt uiteindelijk weer tot een effect dat maatschappelijk relevant is. 


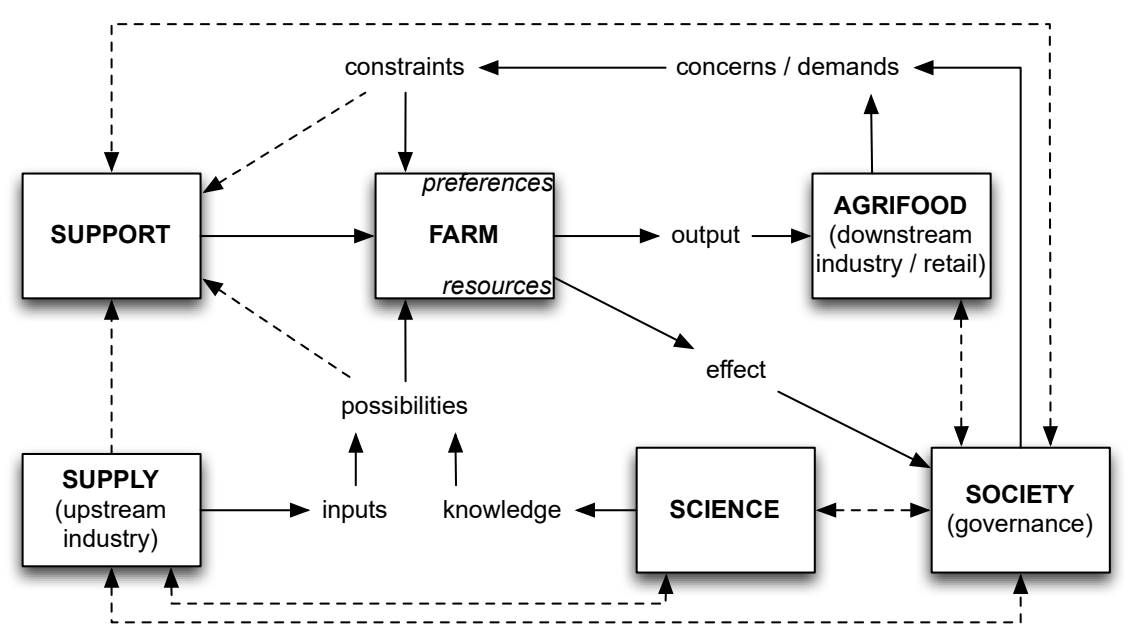

Figuur 3 Operationele omgeving van de akkerbouwer (Van der Wal, 2014).

Als illustratie is een exploratieve uitsplitsing van de in Figuur 3 genoemde stakeholders hieronder weergegeven.

\subsubsection{Bedrijfsleven Agrifood}

De agrarische producten (output) worden over het algemeen via een tussenhandel verkocht aan:

- De Retail: deze is meer en meer mondiaal georganiseerd, zij het dat elk continent toch nog wel zijn eigen merken kent. Retailbedrijven vertalen "namens" de consumenten voedselveiligheids- en duurzaamheidsvraagstukken in concrete eisen aan leveranciers en telers. Dit heeft o.a. geresulteerd in GlobalG.A.P. en diverse andere duurzaamheidsinitiatieven (breder dan enkel de agrarische sector). De eisen die men stelt aan gebruik van meststoffen en gewasbeschermingsmiddelen, en zeker ook de documentatieverplichtingen die daarbij horen, zijn te relateren aan de inzet van drones en/of andere sensortechnologieën voor vastlegging en monitoring.

- Verwerkers: de grote verwerkers van agrarische producten zijn vaak ook multinationals die agrarische grondstoffen verwerken tot (half)producten voor de biobased industrie. Ook zij doen mee in duurzaamheidsprojecten. Deze bedrijven worden aangesproken op hun milieu-footprint en vanuit die invalshoek, samen met het belang om de boer een goed product te laten leveren, sturen deze bedrijven ook aan op meer inzet van precisielandbouw en daarmee ook drones. Door de relatie met de telers hebben deze bedrijven ook een belang bij een economisch rendabele en gezonde landbouw, waar nieuwe technologie een onderdeel van uitmaakt.

\subsubsection{Bedrijfsleven Leveranciers}

- Leveranciers precisielandbouw: aan de aanbodkant zijn het de leveranciers van precisielandbouw apparatuur die een rol spelen in het stimuleren van het gebruik van drones. Onder andere machinefabrikanten en technologieleveranciers brengen zelf een drone op de markt of werken samen met leveranciers.

- Leveranciers van inputs (m.n. agrochemie en meststoffen) zijn actief in het onderzoek naar drones en met name hoe sensors informatie kunnen leveren voor betere benutting van de inputs.

- Support: de ondersteunende bedrijven, zoals adviseurs en laboratoria, zijn van groot belang om sensordata te vertalen in een handelingsperspectief voor de boer. Ook zij investeren in dronetechnologie. Een opkomend domein zijn de ICT-bedrijven die met hardware en software inspelen op de toenemende tendens van de data-gedreven landbouw. ICT-oplossingen komen overigens ook vanuit andere leveranciers en afnemers.

\subsubsection{Wetenschap}

Met haar onderzoeks- en opleidingsinstellingen heeft Nederland een vooraanstaande positie in de duurzame agrarische kenniseconomie. De toepassing van technologie in de landbouw wordt zowel aan landbouwzijde en aan technologiezijde omarmt. 
- Kennisinstellingen landbouw: Wageningen Universiteit \& Research (WUR) is in Nederland de belangrijkste kennisinstelling op het gebied van landbouw. Het is een conglomeraat voor onderwijs en onderzoek. Naast wetenschappelijk onderzoek herbergt WUR ook tal van praktijkcentra. Er zijn naast WUR ook andere kennisinstellingen waar landbouw en voeding onderwerp van studie zijn.

- Kennisinstellingen technologie: de technologie van drones wordt vooral onderzocht en ontwikkeld op de Technische Universiteiten van Eindhoven, Delft en Enschede. Daarnaast zijn ook het Nationaal Lucht- en Ruimtevaartlaboratorium (NLR) en TNO actief in dit domein. Ook de European Space Agency (ESA) is actief op dit vlak;

- Onderwijs: de genoemde universiteiten zijn uiteraard ook actief in het onderwijs over ontwikkeling en/of toepassing van drones voor de landbouw. Daarnaast wordt dit ook gebracht in het hoger beroepsonderwijs, zowel door de van oorsprong agrarische scholen Aeres Hogeschool, HAS Den Bosch en Van Hall Larenstein als door andere hbo-instellingen.

\subsubsection{Maatschappij}

- Belangenorganisaties Landbouw: de maatschappelijke opinie wordt onder andere door belangenorganisaties verwoord. De landbouw kent in ieder geval LTO Nederland, de Land- en Tuinbouw Organisatie die als samenwerkingsverband van LTO Noord, ZLTO en LLTB landelijk de belangen behartigt. Daarnaast is er de branchevereniging van loonwerkers CUMELA. Loonwerkers zijn doorgaans early adopters van nieuwe technologie en ook in Nederland zijn er diverse loonwerkers die drones in hun dienstenpakket hebben opgenomen.

- DARPAS: de Nederlandse vereniging van dronebouwers en -vliegers speelt een rol in het verdedigen van de belangen van deze sector en is het voornaamste aanspreekpunt. Met name de discussie rond regelgeving wordt door DARPAS vanuit die sector gevoed.

- Overheden: een breed scala aan overheden is betrokken en belanghebbend bij het gebruik van drones in landbouw en natuur. Het ministerie van IenM is verantwoordelijk voor de wet- en regelgeving omtrent drones. De hieronder ressorterende Inspectie van de Leefomgeving en Transport (ILenT) gaat over de handhaving van regels in het luchtruim. Ministerie van EZ gaat over de landbouw en natuur en borgt naast de economische belangen ook de handhaving van bv. de flora- en faunawet (verstoringen).

- European Aviation Safety Agency (EASA): de veiligheid en daaruit volgende regelgeving omtrent de luchtvaart in Europa is door de Europese Commissie gedelegeerd aan de EASA. Ook het certificeren en keuren van luchtvaartuigen valt onder de EASA. Drones vallen ook onder de luchtvaart en al vallen de kleine luchtvaartuigen onder de landelijke regels, de EASA is de partij die dit Europees gaat harmoniseren. Grotere drones vallen nu al onder de Europese regelgeving.

De volgende categorie stakeholders bestaat vooral uit partijen die invloed uitoefenen op de sector, vaak via het sturen van geldstromen of het stellen van eisen via betalingsregelingen, wetgeving of voorwaarden aan financieringen. Het is van belang dat er bij deze stakeholders ook draagvlak en ondersteuning is voor precisielandbouwactiviteiten van boeren.

\subsubsection{Financiers}

- EU: het Europese landbouwbeleid kent diverse ondersteunende maatregelen voor de boeren, maar stelt ook vergroeningseisen daaraan. Het is niet ondenkbaar dat precisielandbouw toegevoegd wordt aan de mogelijkheden van boeren om vergroening in te vullen. Daarnaast heeft de EU een aantal innovatie-stimuleringsmaatregelen, zoals het European Innovation Partnership waaruit onder andere de begeleiding van Operational Groups gefinancierd kan worden. In het Horizon2020onderzoeksprogramma is ook ruimschoots aandacht voor de inzet van drones.

- Ministerie van EZ: zij zijn de partij die het Europese landbouwbeleid omzetten in landelijk beleid en wetgeving. Hierin moet voldoende ruimte zijn voor het toepassen van precisielandbouwmaatregelen en het stimuleren van precisielandbouw. Tevens is het ministerie een grote stimulator van vernieuwing en innovatie met het topsectorenbeleid. Ook biedt EZ mogelijkheden voor ondersteuning van het mkb.

- Banken: zij financieren veel boerenbedrijven en daarmee innovaties. Zij zijn daarmee een belangrijke partner als boeren zich op precisielandbouw gaan richten. 


\subsubsection{Publieke opinie}

- Ngo's: het voedsel dat we eten en het milieu waarin het geproduceerd wordt, is het onderwerp van natuur- en welzijnsorganisaties. De invloed die zij uitoefenen op de maatschappij en de wetgeving is over het algemeen vrij hoog. Ngo's die een duurzame landbouw promoten, kunnen een belangrijke stakeholder zijn voor de invoering en acceptatie van drones. Ook in het natuurdomein zijn ngo's een opiniërende factor. Waar in de landbouw nauwelijks weerstand bestaat, is in de natuur met name de verstoring van dieren een belangrijk kritiekpunt op de inzet van drones.

- Journalistiek: systematisch journalistiek onderzoek, als achtergrond of naar aanleiding van actualiteit, zorgt voor een brede kennisbasis en context waarin ontwikkelingen plaatsvinden. $\mathrm{Er}$ is een rol voor de (onderzoeks)journalistiek om het maatschappelijk debat over technologie en technologische innovaties te faciliteren. De maatschappelijke impact van drones wordt onder andere door journalisten belicht.

- Media: naast journalisten bedienen steeds grotere groepen mensen zich van allerlei kanalen om boodschappen, meningen en kennis te delen. Met name sociale media spelen een toenemende rol in de maatschappelijke opinievorming. Dat kanaal stelt mensen in staat een bericht snel te delen ('viraal gaan') wat ook weer door andere massamedia kanalen wordt opgepikt, zoals radio en tv. Het gebruik van drones voor het maken van beelden kan materiaal opleveren dat via sociale media snel verspreid wordt.

\subsection{Stand van Zaken gebruik}

\section{INZETBAARHEID}

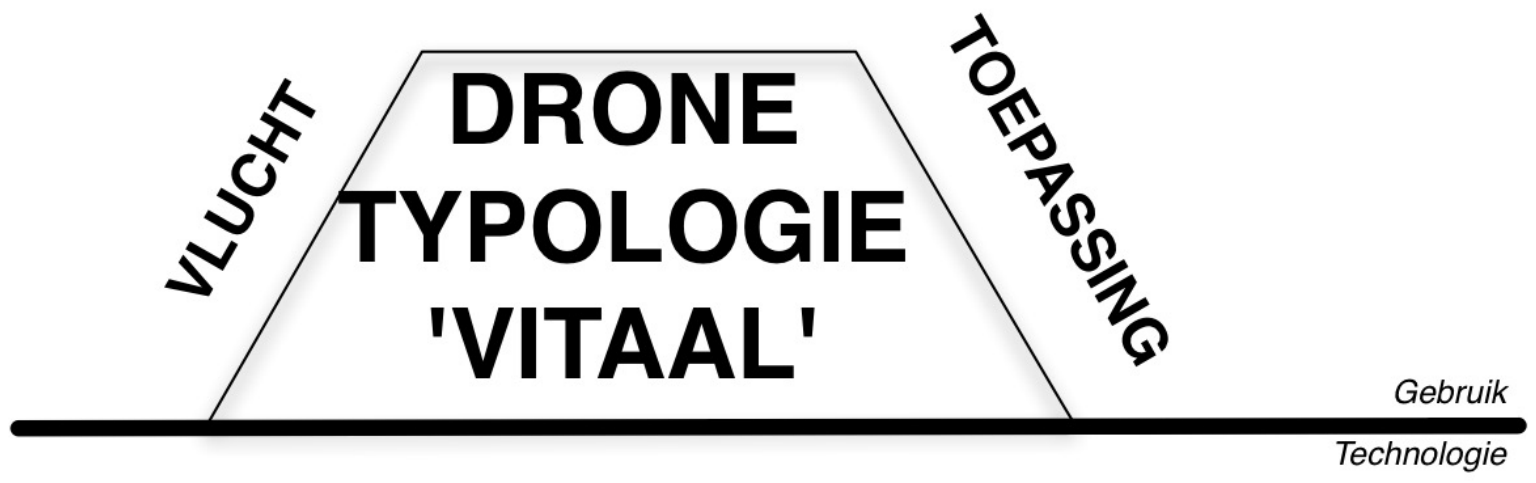

Figuur 4 De 'bovenkant' van het typologieraamwerk voor drones, waar de gebruiksaspecten Vlucht, Inzetbaarheid en Toepassing geduid worden.

\subsubsection{Vlucht}

De eigenlijke vlucht - ook wel Operation genoemd - omvat de inzet van piloot, drone en communicatieapparatuur op een specifieke plaats en een specifieke datum/tijd. De operatie is ook een apart onderwerp in de regelgeving, waarbij onderscheid is gemaakt naar diverse soorten operaties. Zo is er bijvoorbeeld een onderscheid in zichtvluchten, in Visual Line of Sight (VLOS), en Beyond Visual Line of Sight (BVLOS). Voor de regelgeving zijn dit essentieel verschillende operaties waar andere veiligheidsregimes bij horen.

Veel operaties/vluchten met drones zijn bedoeld voor wat de luchtverkeerswet noemt 'luchtwerk': activiteiten en speciale diensten vanuit de lucht, zoals fotovluchten, search en rescue, landbouwwerk et cetera (zie ook missie).

Een belangrijk aspect van de operatie is de veiligheid. Voor veiligheid is het van belang dat de pilot zicht blijft houden op de drone en zijn omgeving. Dit is meestal in vergunningen voor het gebruik van drones vastgelegd. De piloot dient zich dus zo op te stellen dat obstakels als gebouwen of bomen (of mist!) een drone niet aan het zicht kan onttrekken. In de landbouw is dat doorgaans wel mogelijk, maar in de natuur kan dit een probleem vormen. Ook moet de drone afstand houden tot drukke gebieden (congested areas) en luchthavens. 
Omdat de operatie ook het onderwerp van de regelgeving is, worden drones zo ontworpen dat ze binnen regelgevingsklassen vallen, bv. het gewicht en de capaciteit (endurance) van de voortstuwing. De bedrijven die momenteel diensten verlenen met drones doen dat binnen de mogelijkheden van de huidige regelgeving. Deze regels zijn werkbaar en de bedrijven houden hiermee zicht op een commercieel perspectief. Dit wil niet zeggen dat er al heel veel met drones wordt gevlogen, hoewel het aantal vluchten wel toeneemt. Ten opzichte van de marktverwachtingen is het aantal vluchten nog beperkt.

Monique Wordragen is als ondernemer actief met een Nederlandse tak van het Franse bedrijf Airinov (www.airinov.nl). Dit bedrijf biedt Remote Sensing-diensten aan voor de landbouw met gebruikmaking van drones. Airinov heeft een eigen multispectrale sensor ontwikkeld en heeft specifieke kennis ontwikkeld in data-analyse en agronomische modellen, waarmee zij een stap verder kunnen gaan in de adviezen dan andere aanbieders. Airinov is in 2016 actief in Nederland voor een breed portfolio aan klanten, waaronder telers, veredelaars en adviseurs.

\subsubsection{Inzetbaarheid}

De regelgeving is een belangrijk aspect in het huidige gebruik. Regelgeving bepaalt waar drones aan moeten voldoen, hoe operaties uitgevoerd moeten worden en welke eisen er aan piloten gesteld worden. De regels zijn daarmee een belangrijke sturende factor in de ontwikkeling van de sector en zijn medebepalend voor hoe succesvol een businessmodel kan zijn. Het vormt tevens een barrière voor nieuwe toetreders in de dronesdiensten. Een ander probleem voor de landbouw zijn de beperkingen die gelden rondom vliegvelden. Diverse landbouwgebieden liggen immers vlak bij vliegvelden (Schiphol, Lelystad, Eelde, Eindhoven e.a.). Een recent gepubliceerde kaart van het Ministerie van IenM laat zien waar gebieden zijn waar drones verboden of beperkt inzetbaar zijn. Deze kaart geldt voor recreatief vliegen met drones en is ter informatie (Figuur 5). De regelgeving voor drones is nu gebaseerd op de wettelijke regimes die voor de luchtvaart gelden. Maar een vliegende tractor die een gewas bespuit heeft meer weg van een onbemande hovercraft dan van een onbemand vliegtuig. Dus is het de vraag of dit regime in de toekomst nog wel toereikend is, want er wordt geen onderscheid gemaakt in de verschillende dronetypes, missies en payloads.

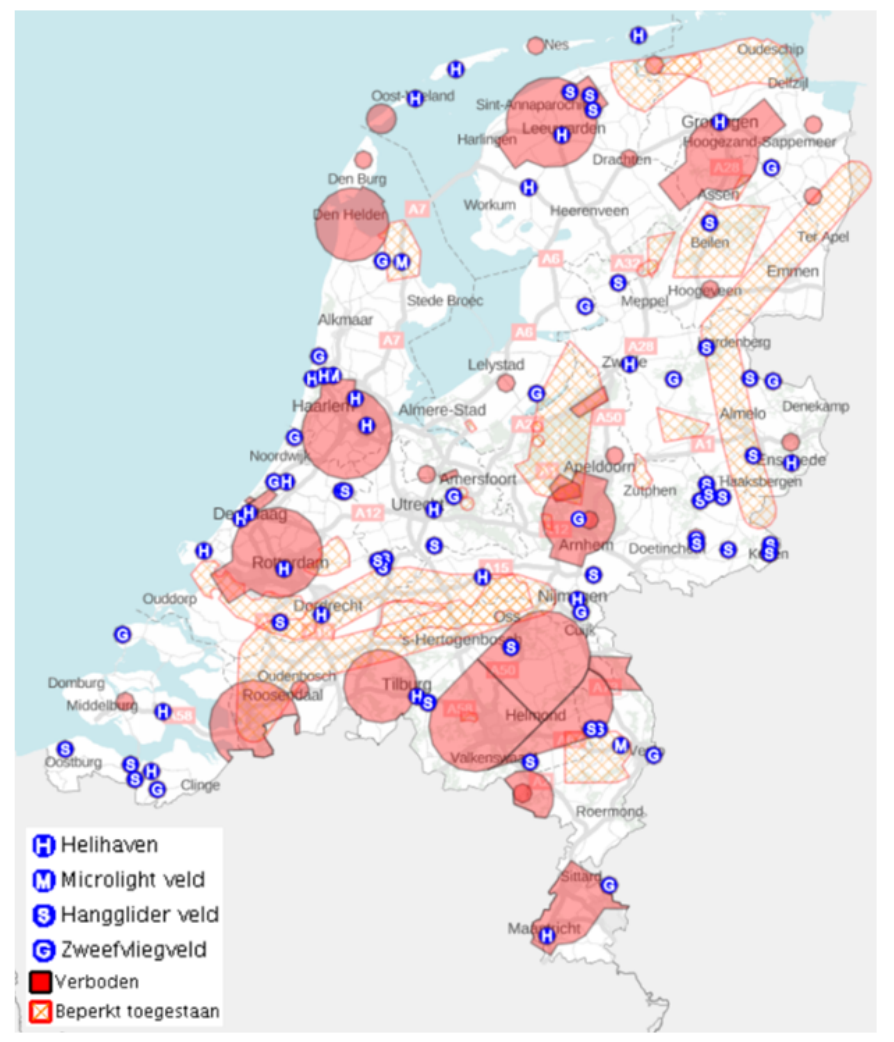

Figuur $5 \quad$ No-flyzones kaart van Nederland voor recreatief vliegen met drones. (bron: www.kadata.kadaster.nl/dronekaart, juli 2016, ministerie I\&M). 
$\mathrm{Er}$ is momenteel nieuwe Europese regelgeving in voorbereiding, specifiek voor drones. In december 2015 presenteerde EASA een Europees raamwerk voor droneregelgeving. EASA gaat daarbij uit van een 'risk based approach' om tegemoet te komen aan de tegenstrijdige belangen van burgers (bescherming van privacy en impact) en industrie (mogelijkheden tot groei en innovatie). Dit raamwerk is verder uitgewerkt en in juni 2016 gepresenteerd aan de sector in een zgn. 'non-paper' ${ }^{2}$.

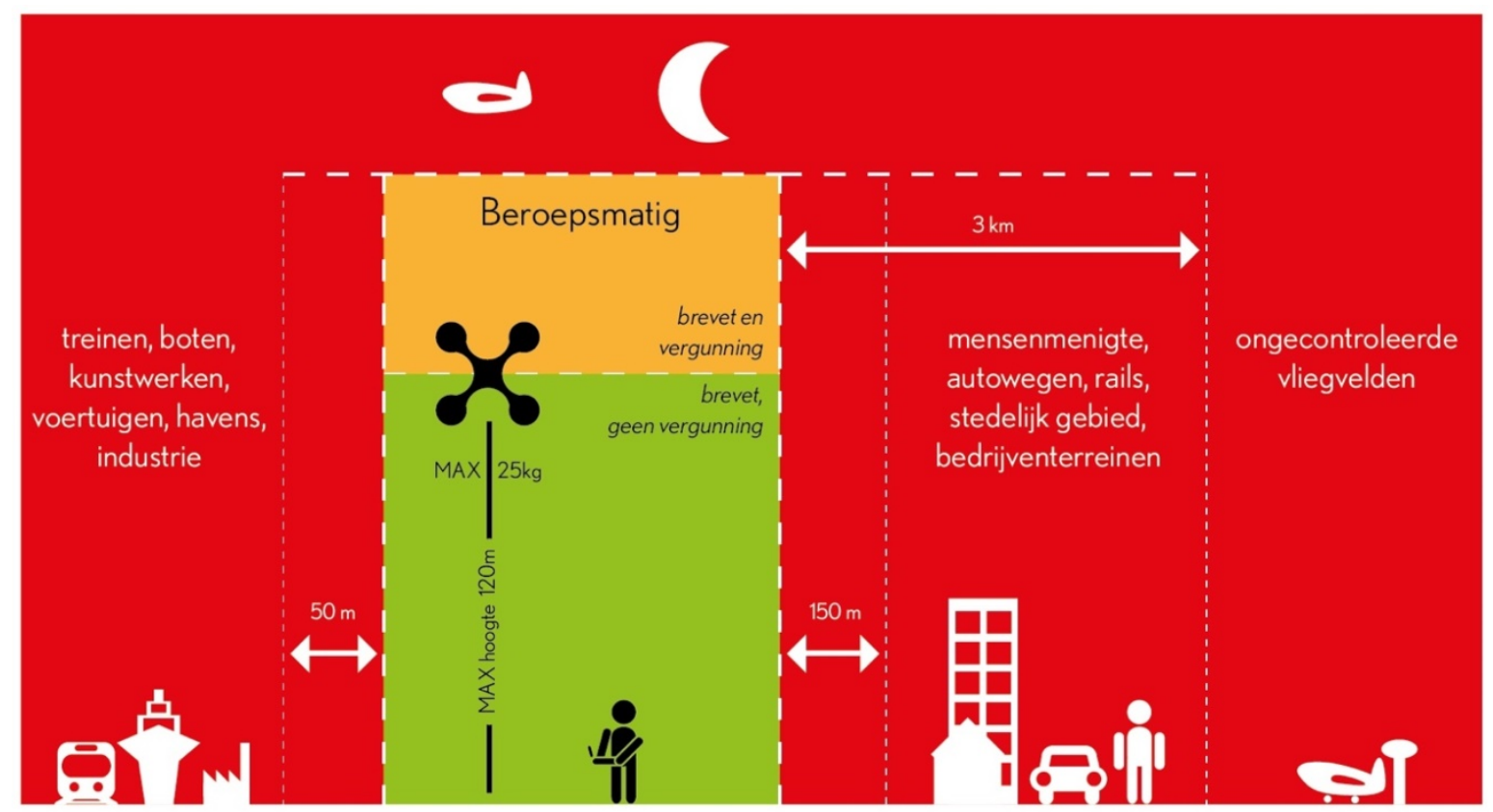

Figuur 6 Wetgeving in Nederland per 1 juli 2016

(bron: Drones - verkenning voor de natuur, Leon op de Beek, Zuivere Speeltijd).

De huidige standaardontheffing en -regelgeving is gevisualiseerd in Figuur 6 . Het geeft de horizontale en verticale begrenzing aan van het luchtruim dat door drones benut kan worden: niet binnen 50 meter van infrastructuur (wegen etc.), niet binnen 150 meter van bebouwde kom of mensenmenigten, minimaal $3 \mathrm{~km}$ van vliegvelden verwijderd, tot maximaal 500 meter van de piloot en niet hoger dan 120 meter boven de grond. Vluchten mogen alleen 'op zicht' worden uitgevoerd, dus ook niet bij nacht of mist. In paragraaf 2.5 worden verschillende voorbeelden van wat er nu al mogelijk is uitgewerkt. De regelgeving rond specifieke gewichtsklassen is een belangrijke indeling. Zo zijn de grenzen tot 2 $\mathrm{kg}^{3}, 25 \mathrm{~kg}$ en $150 \mathrm{~kg}$ startmassa relevant voor specifieke regels ${ }^{4}$ en daarmee interessant om onder te blijven. Regelgeving is in haar aard daarmee een bron van marktsegmentatie. In de praktijk blijkt dat het opstellen en handhaven van generieke regelgeving voor drones erg lastig blijkt. Elke toepassing vraagt eigenlijk om specifieke regels. Aan de andere kant kan dit leiden tot een onoverzichtelijke hoeveelheid regels die leidt tot versnipperde maatregelen.

Vooralsnog zijn de huidige regels voor commercieel gebruik in landbouw en natuur helder en werkbaar. Diverse bedrijven zijn nu al actief in de landbouw. Ondernemers Philippe Serruys (Aurea Imaging) en Monique Wordragen (Airinov) vliegen voor een breed scala aan klanten. Zij kunnen dat binnen de huidige wettelijke mogelijkheden doen. Er is met de huidige regeling een level playing field gemaakt en daarop zijn de ondernemers actief. De kosten die momenteel verbonden zijn aan het verkrijgen van alle juiste papieren zijn echter hoog, wat het voor veel ondernemers, met name kleine bedrijven en zzp'ers, lastig maakt.

2 Roadmap for Drone Operations in the European Union - The roll-out of the EU operation centric approach. Non-paper, besproken op de RPAS stakeholders workshop in Keulen, 20 juni 2016.

3 De voorgenomen Nederlandse regeling om eenvoudiger regels voor lichtgewicht drones toe te passen, was oorspronkelijk 4 voor startmassa $<4 \mathrm{~kg}$. Het lijkt er op dat dit Europees geharmoniseerd wordt op $<2 \mathrm{~kg}$.

4 Regeling op afstand bestuurde luchtvaartuigen, Ministerie van IenM. 


\subsubsection{Toepassing}

De toepassing, ook wel de missie, is het doel van het inzetten van een drone, de taak. 'Missie' is een term die typisch uit het militaire domein en de luchtvaart voortkomt. De taak staat altijd in relatie tot de mogelijkheden van de technologie en omgekeerd, ook al wordt er vaak geoptimaliseerd voor een specifieke taak. Een eerste belangrijk onderscheid in toepassingen vindt haar oorsprong in het type gebruiker en gelieerd gebruiksdoel. Zo kunnen de volgende missies worden onderscheiden:

- militair

- civiel (overheid - niet-militair)

- recreatief

- onderzoek

- commercieel

Deze indeling in toepassingen zegt veel over de aard van de gebruiker - alhoewel bijvoorbeeld militaire drones ook voor civiele missies ingezet kunnen worden en recreatieve drones voor commerciële doeleinden. De toepassing gaat ook over de inzet van de payload, die ook in relatie tot de missie gekozen wordt. Zo is er een ander, meer functioneel onderscheid te maken in missies, zoals in:

- kartering/meting;

- opsporing, inspectie, bewaking, situational awareness etc.;

- film en video;

- transport;

- ingrepen/bewerkingen;

- communicatie/relay e.a.

De toepassing of het gebruiksdoel is een belangrijk aspect als men een drone zoekt voor het uitvoeren van speciale taken. Er is uiteraard een koppeling tussen wat men met een drone wil en welke aspecten er dan van belang zijn. De voorbeelden in de volgende paragraaf geven daar ook invulling aan.

De stand van zaken van toepassingen is moeilijk in te schatten. Veel drones worden momenteel projectmatig ingezet. Van de genoemde typeringen kan gesteld worden dat militair en recreatief zich goed ontwikkelen. Civiel, onderzoek en commercieel zijn aan de wettelijke eisen gebonden die op dit moment de inzet daarvan nog temperen. Een voorbeeld uit de landmeetkunde, waar vijf jaar geleden bedrijven nog enthousiast aan de drone begonnen, laat zien hoe de regelgeving het gebruik beïnvloedt. Voor het 3D inmeten van een gebied ging er meer tijd zitten in het verkrijgen van vergunningen, het vliegen (met piloot én waarnemer) en de verwerking van de data, dan op de gangbare manier inmeten. De drone bleef daarmee op de plank liggen. Maar vroeg of laat zal door verdere technische ontwikkeling of veranderende regelgeving de balans weer naar de andere kant door kunnen slaan. Verschillende bedrijven gaan in 2016 een aantal landbouwpercelen in kaart brengen.

\subsection{Stand van Zaken Technologie}

De technologische ontwikkeling van droneplatformen vindt met name plaats in de trade-off tussen vliegduur en laadvermogen. Er zijn al enkele drones die een persoon kunnen vervoeren. Met betrekking tot autonomie worden er steeds meer sense\&avoid-systemen op de markt gebracht: ontwijkingssystemen voor autonome manoeuvres in de lucht. Zo brengen Intel en Yuneec een nieuwe Typhoon drone uit met Intel's RealSense camera om snel objecten te kunnen ontwijken. Andere technologische ontwikkelingen in de dronetechnologie hebben met name met veiligheid te maken: alternatieven voor de huidige onstabiele radiocommunicatie voor de 'command and control link' tussen piloot en drone, identificatiesystemen, geo-fencing (digitale "verboden toegang"-bordjes) en andere zaken rondom het zo veilig mogelijk opnemen van de drones in de bemande luchtvaart.

De ontwikkelingen van drones in de civiele sector staan nog in de kinderschoenen en volgen elkaar in rap tempo op. Regelmatig komen er nieuwe toepassingen en mogelijkheden voor het gebruik van drones. De ontwikkeling van drones heeft voor relatieve buitenstaanders een stormachtig en 
onvoorspelbaar karakter. Het Rathenau Instituut beschrijft drie belangrijke factoren die aan die onvoorspelbaarheid bijdragen ${ }^{5}$ :

1. Technologieontwikkeling heeft een evolutionair karakter en leidt tot sprongsgewijze vernieuwing, vaak op basis van een doorbraak;

2. Technologieën convergeren, waardoor ze (bezien vanuit de technologie) nieuwe toepassingen mogelijk maken;

3. Standaardisering en 'platformisering' maken innovaties op kleine aspecten mogelijk en geeft ruimte aan kleinere spelers om daaraan bij te dragen.

Deze factoren zijn bepalend voor de ontwikkeling van drones. Toepassingen van mechatronica, ICT, robotica, aerodynamica en elektronica hebben geleid tot doorbraken en convergenties: sensoren en actuatoren hebben de besturing sterk vereenvoudigd en maken autonoom vliegen mogelijk; energiezuinige(re) motoren en optimalisatie van energiegebruik zorgt voor langere vliegduur en dus grotere inzetbaarheid; aerodynamica zorgt voor nieuwe modellen, zoals multi-rotors en de zgn. Flying wing. Gps (satellietnavigatie) zorgt voor navigatie en precisiebesturing met bv. auto-pilots. De drone is tevens een platform geworden voor allerlei payloads die door combinatie met de drone tot revolutionaire mogelijkheden behoren. De drone is een disruptive innovation en ontwikkelt zich op stormachtige en onvoorspelbare wijze.

Voor landbouw en natuur is de combinatie van drone met camera momenteel de meest in het oog springende en de meest wijdverspreide toepassing. Hiermee kunnen actuele karteringen gemaakt worden op basis van spectrale signatuur van de vegetatie of bodem. Deze actuele kaarten zijn daarmee onderdeel van precisielandbouw. Ook voor natuur (kartering van vegetatie, tellen van dieren) bieden drones een uitkomst, omdat ze goedkoper en nauwkeuriger zijn en ook minder verstoring (geluidsoverlast bijv.) geven dan de alternatieven.

Voor monitorings- en karteringsdoeleinden richten de ontwikkelingen zich nu op drones tot $4 \mathrm{~kg}$. Het dragen en positioneren van camera's, voor luchtfoto's of video, is daarbij het belangrijkste doel. Dit is mede ingegeven door de verwachte regelgeving die voor deze lichte drones aanzienlijk eenvoudiger wordt ${ }^{6}$. Voor de landbouw betekent dit toepassingen in de precisielandbouw, waarbij de luchtfoto's gebruikt worden om verschillen in het gewas te detecteren en daarop te reageren met bv. plaatsspecifieke bemesting. In de natuur is het vooral bekend door het gebruik in natuurfilms, zoals De Nieuwe Wildernis (2013) en Holland, Natuur in de Delta (2015). Daarnaast wordt het ook gezien als een nieuwe manier om bv. stropers of bosbranden op te sporen.

De technologie ontwikkelt zich echter op alle fronten. Aan de hand van het typologieraamwerk 'VITAAL' worden de ontwikkelingen van de technologie hieronder besproken, om daarmee een indruk te geven van de mogelijkheden.

Gebruik

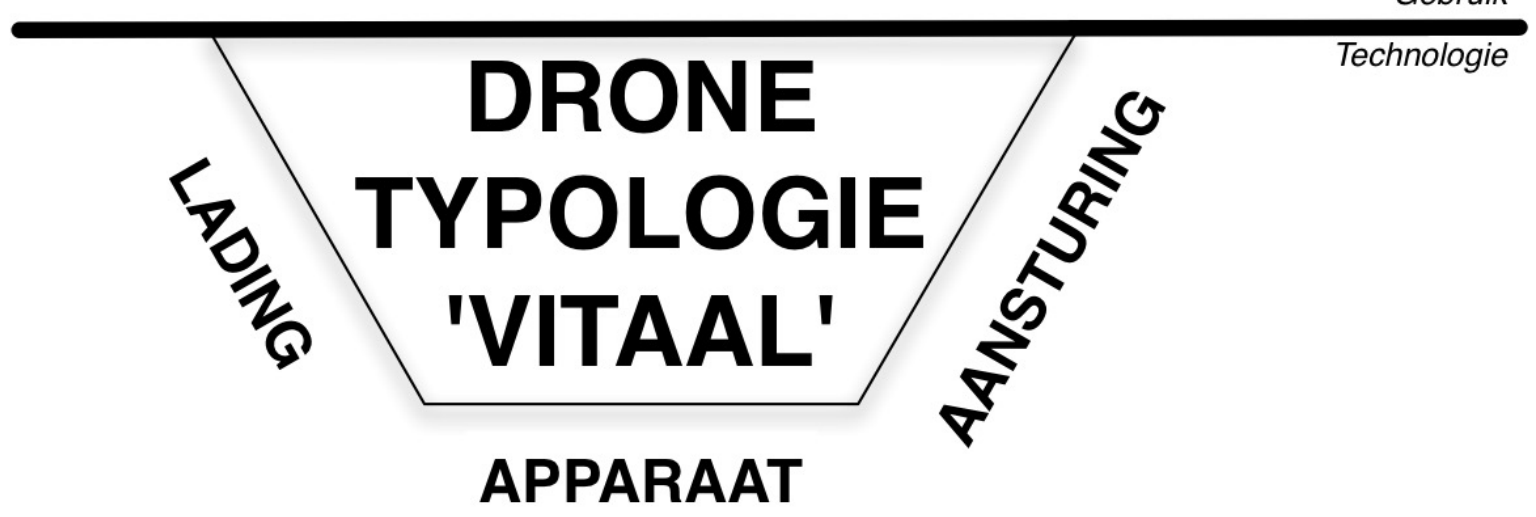

Figuur 7 De 'onderkant' van het typologieraamwerk voor drones, waar de technologieaspecten Aansturing, Apparaat en Lading geduid worden.

\footnotetext{
5 Maclaine Pont, P., R. van Est, J. Deuten (2015). Met beleid vormgeven aan socio-technische innovatie. Den Haag: Rathenau Instituut

6 In Frankrijk is de $4 \mathrm{~kg}$ grens inmiddels vervangen door $2 \mathrm{~kg}$.
} 


\subsubsection{Aansturing}

Zelfsturende machines of robots zijn het ultieme doel van vele technologische visies, met name omdat autonome machines nauwkeuriger kunnen werken, vooral waar het gaat om herhaald en gevaarlijk werk. Maar ook de miniaturisering biedt mogelijkheden. In de landbouw wordt onder andere aan "zorg-robots" gedacht die in plaats van grote machines als een zwerm kleine bezige mieren het gewas of het land verzorgt. Het biedt daarmee ook mogelijkheden voor de boer om meer productiviteit uit arbeid te halen.

Autonomie van drones betekent het zelfstandig opstijgen en landen en het zonder menselijke interventie kunnen uitvoeren van de vlucht. De diverse auto-pilots voor de vliegbewegingen zijn daar al een voorloper van, alhoewel dit doorgaans om geprogrammeerde vliegbewegingen gaat. Zelfstandig opstijgen en landen is voor multi-rotors ook al goed ingevoerd. Voor de fixed wings is dit een grotere uitdaging.

Autonome navigatie bij drones wordt vooral gedaan op basis van gps. Hiermee is de plaats van de drone, zowel op de kaart als in hoogte boven de grond bekend. De auto-pilot kan dan de drone (bij)sturen naar voorgeschreven posities. Er zijn inmiddels auto-pilots met zgn. Geo Fencing die op basis van gps-positie bepaalde grenzen kunnen respecteren. Zo zijn er drones waar een 'operational flight envelope' aangegeven kan worden waarbinnen een drone, op basis van gps-posities, moet blijven. Hier kunnen dan ook obstakels (gebouwen, bomen, elektriciteitskabels etc.) worden aangegeven. Omgekeerd wordt ook gewerkt aan zgn. no-flyzones waar drones juist niet mogen vliegen, zoals vliegvelden of tijdelijke zones boven grote evenementen (Pinkpop bijvoorbeeld). Gps ${ }^{7}$ is een wereldomvattend systeem en werkt derhalve overal. De moedwillige verstoring van gps-signalen ('jamming') is echter een significant risico.

Als variant of tussenstap kan ook het (tijdelijk) overdragen van de controle aan de drone als vorm van autonomie worden gezien. De drone voert daarbij zelfstandig manoeuvres uit en de piloot controleert de bewegingen.

Een belangrijk aspect voor autonomie is de ontwikkeling van zgn. Sense \& Avoid-systemen, waarmee andere luchtruimgebruikers en obstakels gedetecteerd worden en de drone automatisch een uitwijkmanoeuvre in kan zetten. Deze systemen maken bv. gebruik van radar of video. Ook zijn er virtuele verkeerstorens in ontwikkeling die op basis van transponders in de drone posities en koersen kunnen analyseren en zo potentiële aanvaringen kunnen voorkomen.

\subsubsection{Apparaat}

De wetenschappelijke en technologische ontwikkelingen op het vlak van de drone zelf, het apparaat, zijn legio. Belangrijkste doelstellingen daarbij zijn, zoals eerder aangegeven, met name gewichtsbeperking, vliegduurverlenging en het verhogen van de veiligheid.

De hardware van drones bestaat uit een aantal componenten die altijd terugkomen: de drone zelf bestaat uit het airframe, de motor, de energiebron (batterij of brandstof), de vluchtcontrole-unit (incl. sensoren) en de unit voor communicatie met de piloot. Een primair kenmerk van een dronesysteem is de vliegwijze, namelijk een onderscheid tussen vleugels of rotors. Een drone met vleugels, ook wel 'fixed wing' genoemd (Figuur 8), maakt gebruik van de aerodynamica van het vleugelprofiel voor opwaartse kracht en zweefvermogen. Het heeft voorwaartse snelheid nodig om de lucht langs de vleugel te laten stromen.

\footnotetext{
7 Dit is onderdeel van de Global Navigation Satellite Systems (GNSS), waartoe naast gps (USA) ook GLONASS (Rusland), Beidou/Compass (China) en Galileo (Europa) behoren.
} 


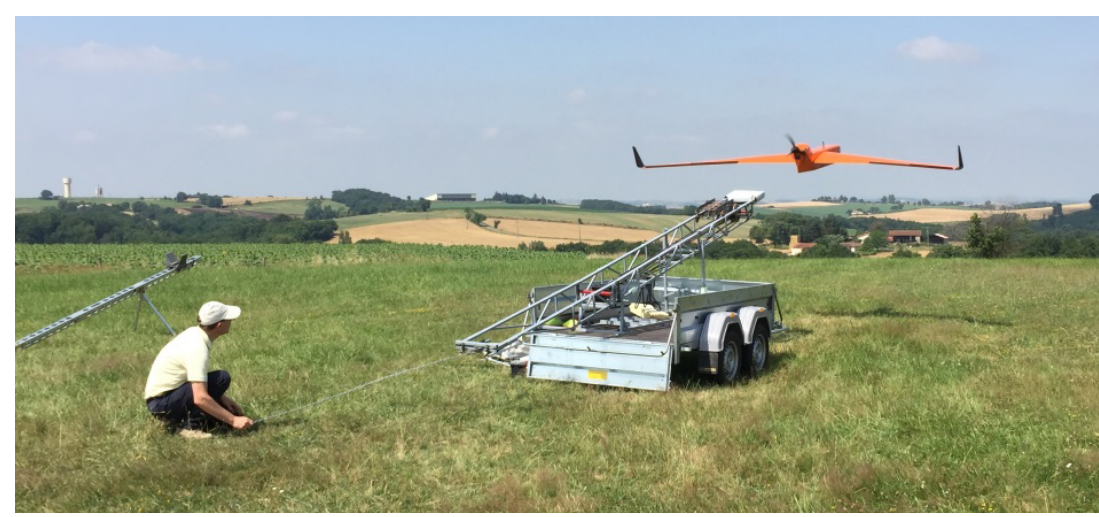

Figur 8 'Fixed Wing'-voorziening.

Rotors daarentegen, zoals gebruikt door helikopters, maken gebruik van de opwaartse kracht door zelf de rotorbladen met snelheid door de lucht te bewegen. Hierdoor biedt het de mogelijkheid van 'Vertical Take-off and Landing' en kan een helikopter stil in de lucht blijven hangen. Er zijn inmiddels ook hybriden, die verticaal opstijgen en landen maar in de lucht vliegen als een vleugel met een hogere energie-efficiëntie (en dus een grotere vliegduur).

De ontwikkeling in elektrische motoren en batterijen heeft de technische ontwikkeling van drones verder aangejaagd. Ook is de sensortechnologie enorm verbeterd, zodat met o.a. 3D accelerometers, elektronische gyroscopen, kompassen en computerprogramma's de elektrische motoren worden bestuurd. Hierdoor wordt de stabiliteit van de drone automatisch geregeld. Dit principe zorgt voor een veel eenvoudiger besturing: de piloot kan zich concentreren op de koers en snelheid. En zelfs dat kan door auto-pilots worden overgenomen, zodat de piloot zich nog meer op de omgeving en de toepassing kan richten (zie 'aansturing').

Een belangrijk onderdeel van het drone-systeem is de communicatie met de piloot. Deze communicatie begint bij het besturingsdeel, maar omvat ook informatie ter ondersteuning van de vlucht, zoals vliegparameters (hoogte, kompaskoers etc.), energieaspecten (bv. resterende vliegduur), motormanagement en het functioneren van onderdelen etc. Wat er kan gebeuren als de communicatie wegvalt, werd geïllustreerd door een ongeval met een Belgische onderzoeksdrone. Nadat de communicatie met de piloot weggevallen was, heeft het toestel nog twee uur doorgevlogen tot de brandstof opraakte boven Frankrijk ${ }^{8}$. Dronefabrikanten bouwen doorgaans een aantal zekerheden in, zoals een automatische noodlandingsprocedure of een 'Return-to-Base'-instructie, waarbij de drone onbegeleid terugkeert naar de plaats van vertrek. Zo zijn er systemen die bij verlies van communicatie met de piloot zelf terugvliegen naar de plek van vertrek en daar op 10 meter hoogte blijven zweven totdat de piloot het toestel landt (of de energie opraakt).

\subsubsection{Lading (Payload)}

Voor de toepassingen van drones zijn de payloads wellicht het belangrijkst. De payload immers is van groot belang voor de missie (het doel van de vlucht). Er zijn drie payload-types te onderscheiden:

1. Sensoren voor inspectie en monitoring: dit zijn onder andere camerasystemen voor bijvoorbeeld vegetatiemonitoring, videosystemen (opname en/of realtime) en andere type sensoren, zoals warmtebeeldcamera's, laserscanners, radarsystemen etc.;

2. Robotics en mechanische apparaten: bijvoorbeeld sproei-installaties voor bemesting of gewasbescherming in de landbouw, of messen om op lastig bereikbare plaatsen te snoeien;

3. Cargo: het vervoeren en afleveren van allerlei zaken en mensen door de lucht met de drone als logistiek verlengstuk van bestaande mogelijkheden.

Met name in de ontwikkeling van camerasystemen is grote vooruitgang geboekt in de afgelopen jaren. Zo zijn er camera's geminiaturiseerd met mogelijkheden die tot nu toe voorbehouden waren voor de

8 http://deredactie.be/cm/vrtnieuws/binnenland/1.2587390 
luchtfotografie of satelliet-aardobservatie. Haast alle toepassingen uit die domeinen zijn direct vertaalbaar in toepassingen voor drones. Daarmee vormt de drone een alternatief voor satellieten en bemande vliegtuigen: de gebruiker heeft veel meer invloed op wat er wanneer en hoe in beeld gebracht wordt. Bovendien biedt de elektrische aandrijving mogelijkheden om met veel minder herrie en veel minder risico (dan bv. bemande helikopters) opnames te maken.

De robotica en mechanische apparaten zijn in veel gevallen nog niet marktrijp. Bestaande voorbeelden zijn het nemen van watermonsters in het midden van een meer of natuurgebied (als goedkoper en minder verstorend alternatief voor een bootje met onderzoekers) en het bespuiten van gewassen (gewasbescherming of vloeibare meststoffen). Met name deze laatste ontwikkeling is in Japan al twintig jaar een van de belangrijkste toepassingen van drones.

Het vervoeren van mensen of goederen heeft veel aandacht gekregen door de initiatieven van o.a. Amazon die haar pakketjes op deze wijze efficiënter wil bezorgen. Een bijzondere variant daarvan is door de TU Delft ontwikkeld als vliegende AED (Automatische Externe Defibrillator). In de landbouw kunnen we denken aan het bezorgen van 'rietjes' van de KI, medicijnen of onderdelen van machines. In de natuur kan het een dienst voor parkbezoekers zijn om bv. warme koffie of een lunch te bezorgen. Het vervoer van mensen vergt een grotere capaciteit van drones dan de hiervoor genoemde voorbeelden, maar ook deze ontwikkeling loopt.

\subsection{Gebruik in de landbouw}

\subsubsection{Voorbeelden akkerbouw}

In de Nederlandse landbouw worden drones nog niet op heel grote schaal toegepast. Een aantal boeren experimenteert zelf met drones en het maken van luchtopnames van de gewassen. Veelal worden hiervoor de meer hobbymatige drones ingezet met een normale RGB-camera. Het heeft dan ook meestal geen bijzondere landbouwkundige toepassing. Het levert vooral mooie foto's op (Figuur 9). Toch leveren deze foto's in combinatie met het scouten van het gewas voor de boer relevante informatie op over de verdeling van de stand van zijn gewas over het veld.
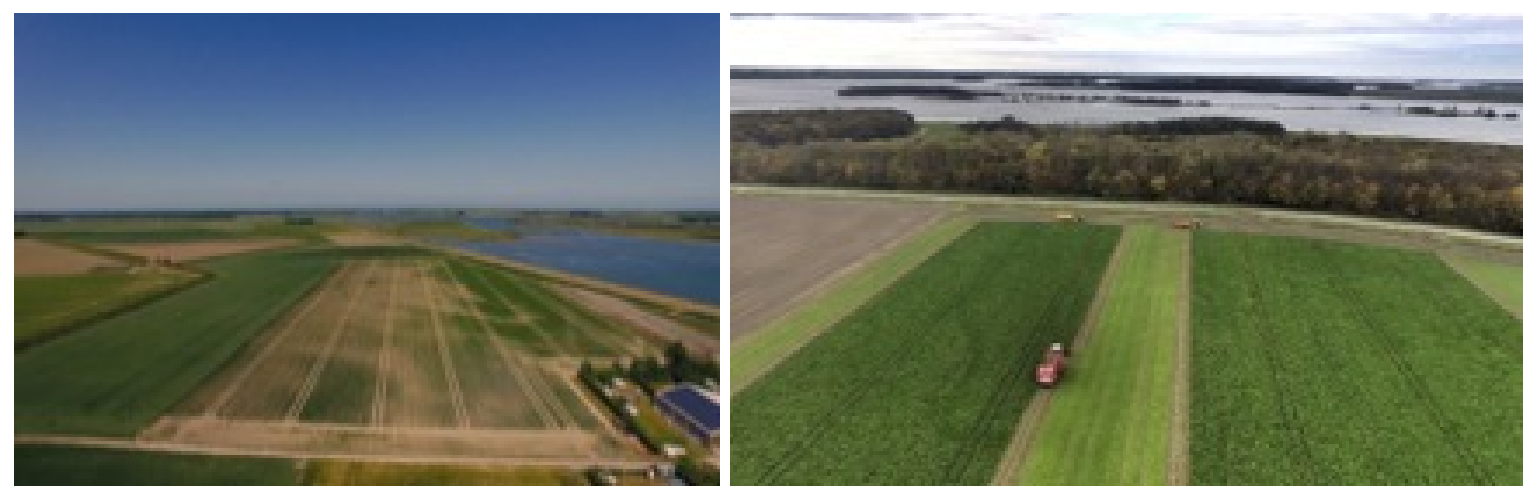

Figuur 9 Door een boer gemaakte beelden van gewas en oogstvoortgang.

Boeren raken hierdoor geïnspireerd. Van nature is de agrarische sector altijd op zoek naar innovaties die helpen bij het besparen van kosten of optimaliseren van inputs. Voor de akkerbouw in Nederland is met name de voeding van het gewas, de mest, een groot punt van zorg. De prijzen van kunstmest variëren en kunnen soms heel hoog zijn, maar belangrijker nog is de forfaitaire mestnorm van 170 $\mathrm{kg} /$ ha per jaar. Bij uniforme verdeling komt er op sommige plaatsen te veel, en op andere te weinig stikstof.

Een hulpmiddel daarbij is een goede analyse van de stikstofopname. Hiervoor bieden drones een goede uitkomst. Uitgerust met een multispectrale camera kunnen dronebeelden de stikstofopname in 
het gewas meten. Een alternatief is de 'gewone' vegetatie-indexberekening, zoals de NDVI of WDVI'. De vertaling naar stikstof is ook hier goed mogelijk. Het aantal Nederlandse boeren dat hun gewas laat inmeten/monitoren voor dit soort doeleinden neemt snel toe (Figuur 10). De eerdergenoemde bedrijven Aurea Imaging en Airinov zijn hierin actief, net als een aantal piloten die zich verenigd hebben onder de vlag van Drone Werkers.
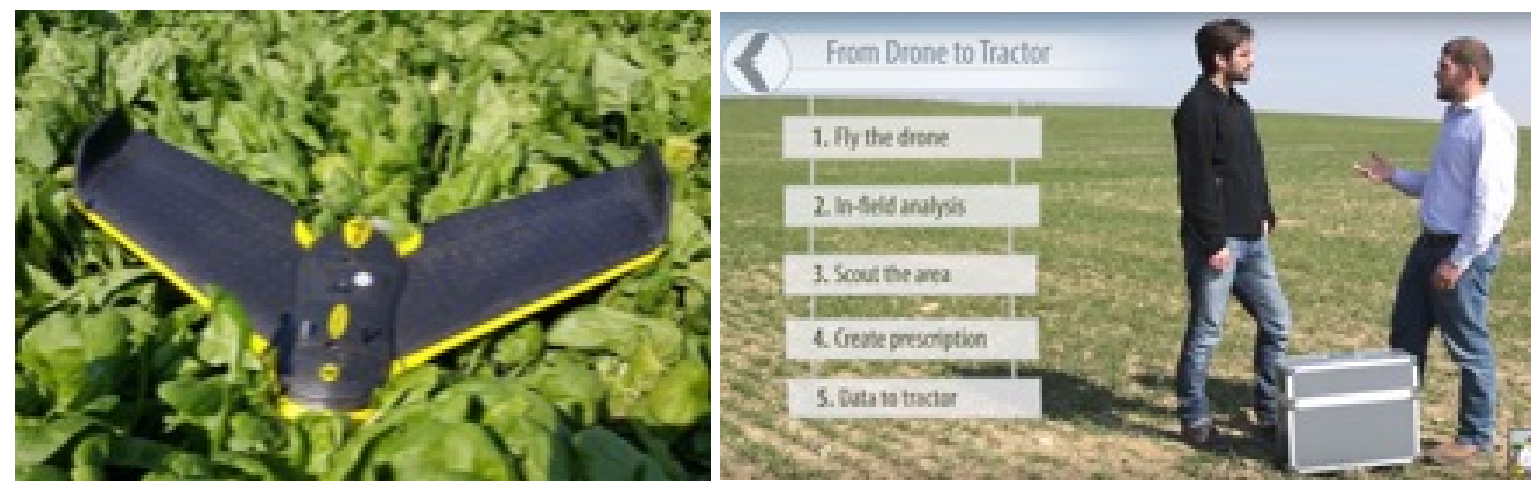

Figuur 10 De e-Bee, voorbeeld van een professionele drone op de commerciële markt (bron: senseFly).

Het is vaak nog zoeken naar de juiste vertaalslag van de informatie uit de drone naar gerichte handelingen op het veld. Toch zijn er al duidelijke toepassingen. Zo valt veel spuitmiddel, en daarmee ook geld, te besparen bij gewasbescherming van aardappels en zijn er ook rekenregels beschikbaar voor het bijmesten van aardappels en graan. Er zijn enkele droneoperators actief op de Nederlandse markt die dergelijke diensten aanbieden.

Een andere wens van boeren is het "tellen" van het aantal planten op het veld (Figuur 11). Vooral in de teelt van koolgewassen (bloemkool, broccoli, boerenkool en spruiten) is dit een interessante toepassing. Daarmee wordt duidelijk of er genoeg planten gekiemd zijn om het veld volledig en rendabel dicht te leggen. Maar ook bij suikerbieten speelt het kiemen een rol en is medebepalend voor eventuele overzaai.
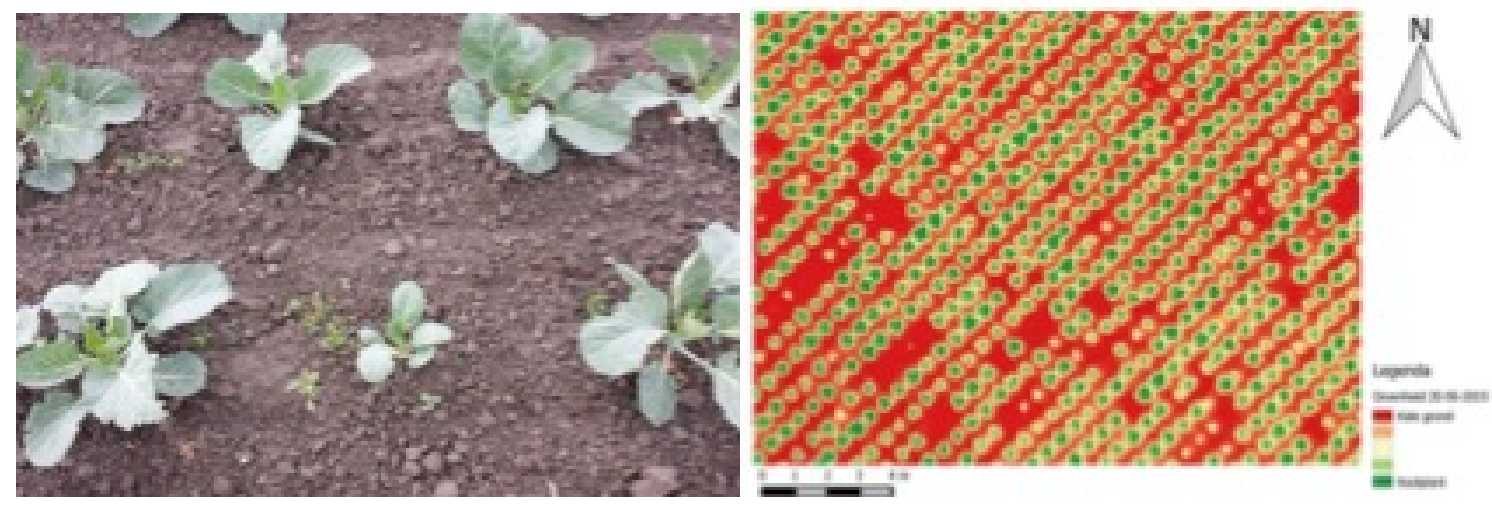

Figuur 11 Het tellen van koolplanten (bron: Twitter @BertRijk).

Jacob van den Borne, een aardappelteler op de Kempense zandgronden, is een pionier op het gebied van precisielandbouw. Hij gebruikt diverse sensoren om het gewas en zijn bodem in te meten en deze informatie te gebruiken bij het managen van zijn teelten en het aansturen van zijn machines. Hij is

9 Normalised Differential Vegetation Index (NDVI) en Weighted Differential Vegetation Index (WDVI); maat voor biomassahoeveelheid. 
echter zeker niet de enige, want ook boeren in de Hoekse Waard maken in georganiseerd verband gebruik van drones en andere Remote Sensing-beelden. Ook het NLR in Marknesse is actief op het gebied van drones, o.a. als keurings- en opleidingsinstituut voor drones en in het testen van toepassingen en payloads.
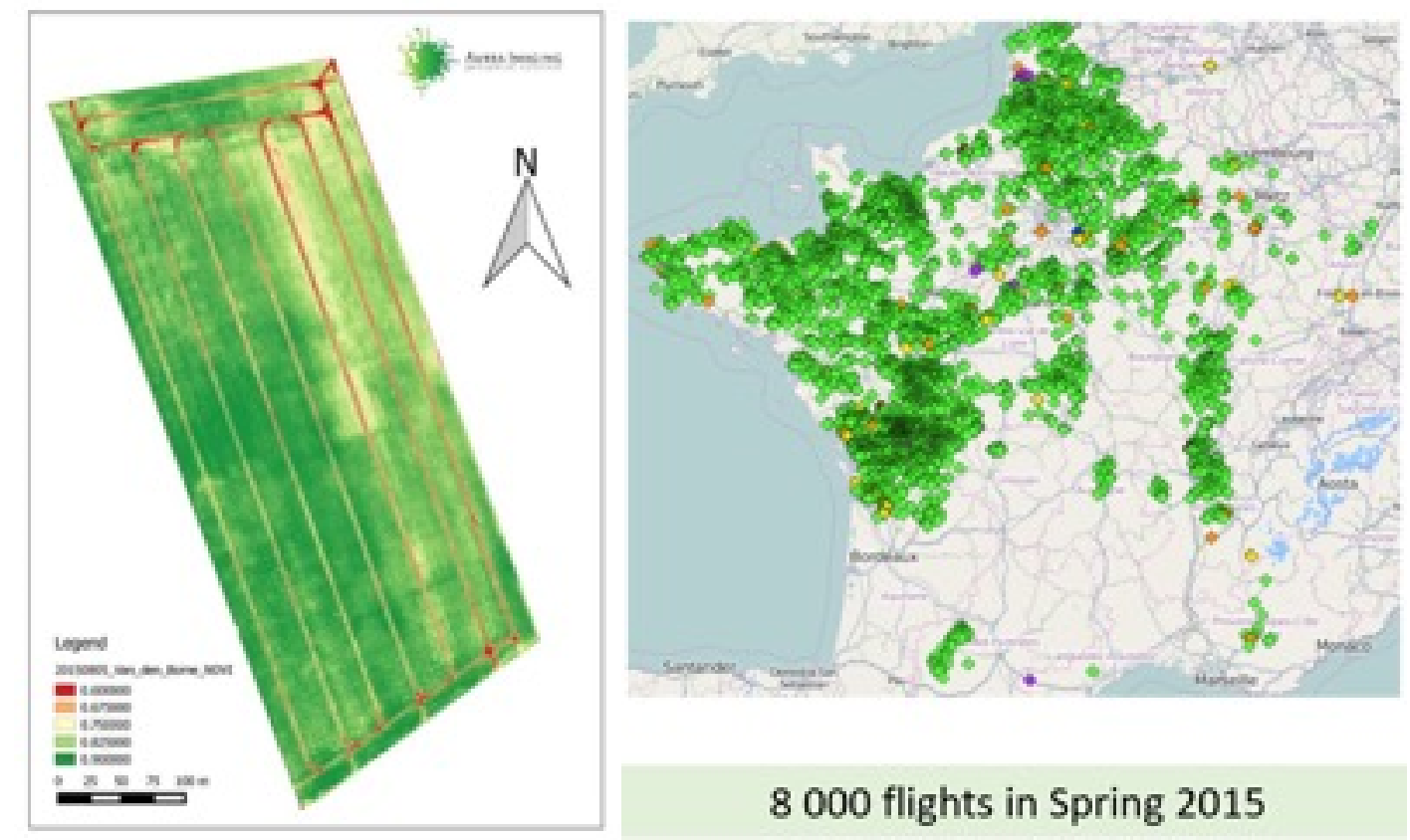

Figuur 12 Een aardappelperceel bij Jacob van den Borne (links). Rechts: het aantal vluchten van de Franse droneoperator Airinov (bron: Airinov-website).

Het gebruik van sensoren en drones in het buitenland lijkt groter dan in Nederland. Figuur 12 (rechts) geeft het aantal vluchten van een droneoperator in Frankrijk. Zij zijn niet de enige operator in Frankrijk. Dit voorbeeld gaat bovendien alleen over tarwe. Bekend is dat in de wijnbouw al veelvuldig van drones (of kleine bemande vliegtuigen) gebruikgemaakt wordt voor het inmeten van de wijngaarden, o.a. voor het bepalen van het juiste oogstmoment en de locaties die als eerste of juist als laatste geoogst moeten worden. Het bedrijf L'Avion Jaune (www.lavionjaune.com) is op dit vlak actief. De betrokkenheid van overheden in de ontwikkeling en toepassing van drones in de landbouw is nagenoeg nihil, anders dan het aanmoedigen van ondernemerschap en het financieren van gerelateerd onderzoek.

Vele droneleveranciers werken aan een landbouwdrone. Het Nederlandse bedrijf Aerialtronics heeft een speciale use case voor landbouw opgezet (Figuur 13).
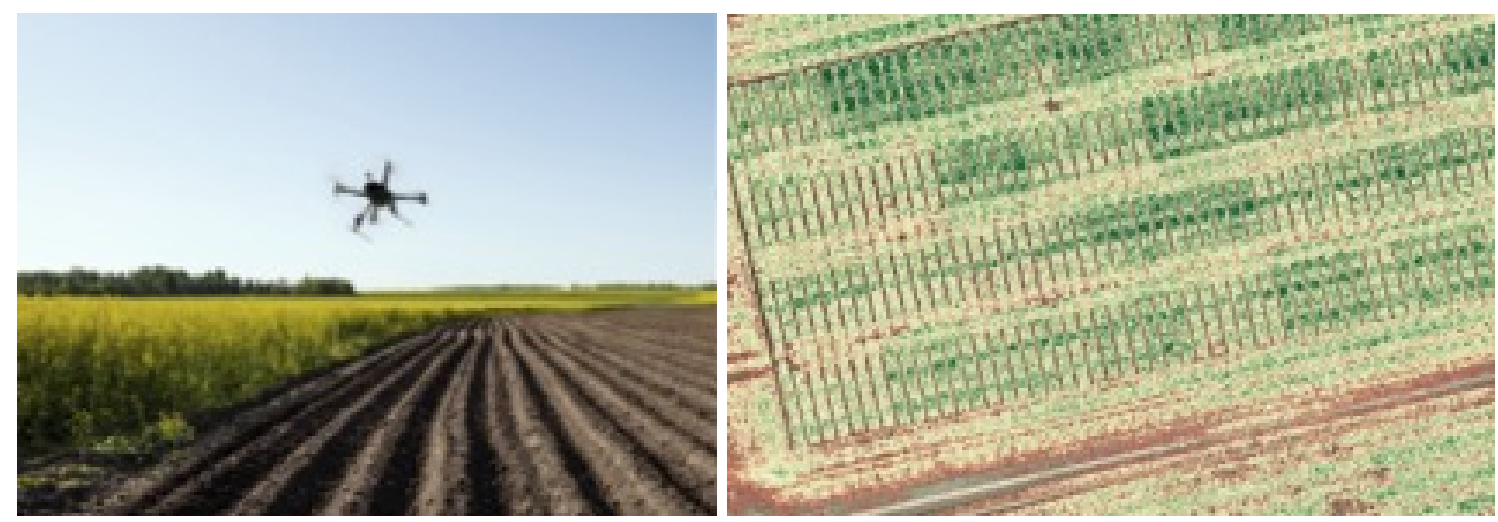

Figuur 13 De landbouwdrone van Aerialtronics, gericht op inspectie van gewassen (bron: aerialtronics.com). 
Landbouw- en met name gewasmonitoring is een toepassing waarbij droneontwikkelaars zich wel iets voor kunnen stellen. Er zijn enkele succesvolle fixed-wings in de markt (zoals de Trimble UX-5, de eBee en de Lancaster) die meerdere type camera's kunnen inzetten: RGB fotocamera, een 4-bands camera met NIR-sensor of een multispectrale camera met meerder banden, al dan niet instelbaar. De camera, de payload, bepaalt in feite het gebruik. Het Chinese bedrijf DJI komt ook binnenkort met een thermische camera op de markt. Thermische camera's laten de temperatuur van een oppervlak (het gewas) zien (zie Figuur 14). Temperatuurverschillen worden voornamelijk veroorzaakt door verschillen in gewasverdamping, waarbij hoge temperaturen dus duiden op waterstress van de planten. In Spanje worden thermische beelden gebruikt om de irrigatiebehoefte van wijngaarden in kaart te brengen. Dit gebeurt nu met bemande vluchten, waardoor het alleen voor de allergrootste telers betaalbaar is.

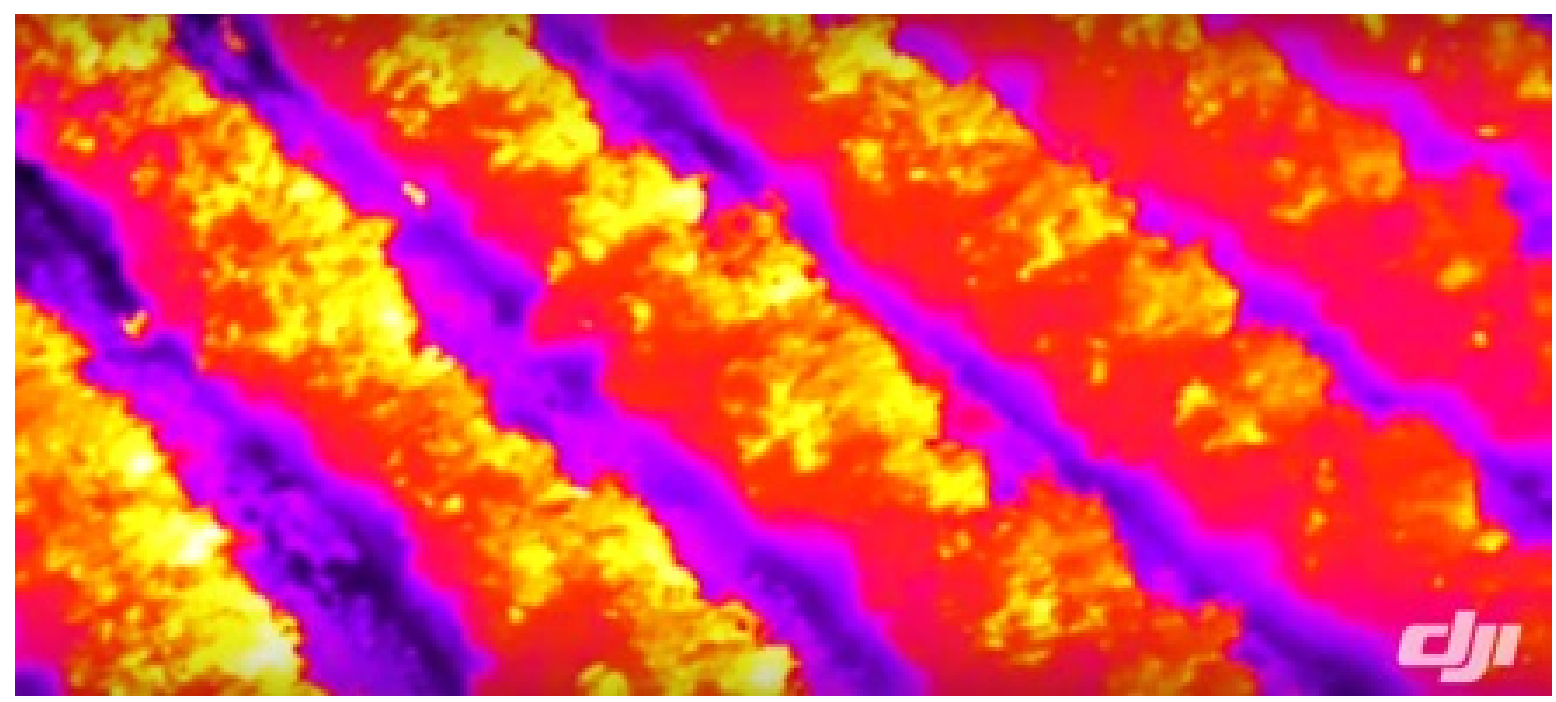

Figuur 14 Thermisch infrarood foto van perceel met rijen fruitbomen (bron: drones.nl DJI).

Figuur 15 (links) toont een operator die van een grotere drone gebruikmaakt om rijstvelden mee te bespuiten. Als we in ogenschouw nemen dat de agrarische sector wereldwijd te maken heeft met bodemverdichting door de zware landbouwmachines, is dit een zeer interessante toepassing.
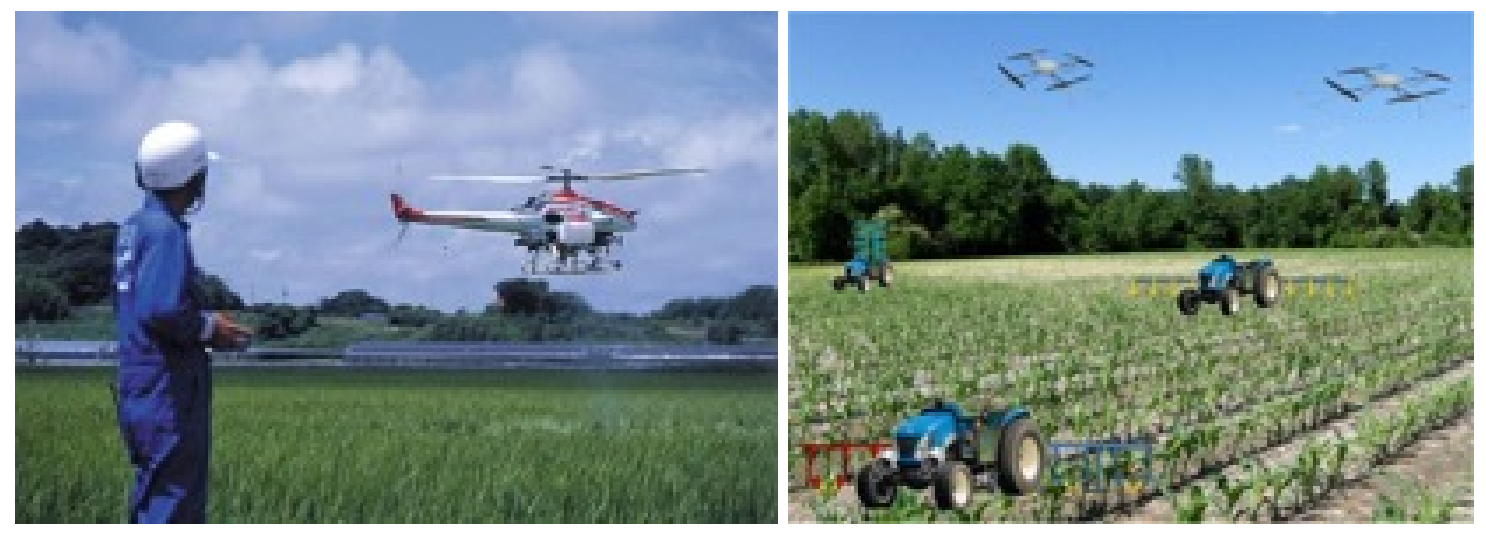

Figuur 15 In Japan worden drones gebruikt voor het bespuiten van natte rijstvelden (links; bron: Yamaha); Rechts: conceptfoto waarin drones rechtstreeks onbemande tractoren aansturen (bron: rhea-project.eu).

Vanuit die optiek experimenteert het Europese project Rhea met de inzet van drones voor het aansturen van lichte veldrobots (Figuur 15 rechts). 
DJI heeft een speciale landbouwdrone ontwikkeld die $10 \mathrm{~kg}$ aan sproeivloeistof kan meenemen voor precisietoediening. Hiermee is het naast Yamaha een van de eersten die een echte landbouwtoepassing ontwikkeld heeft (Figuur 16).

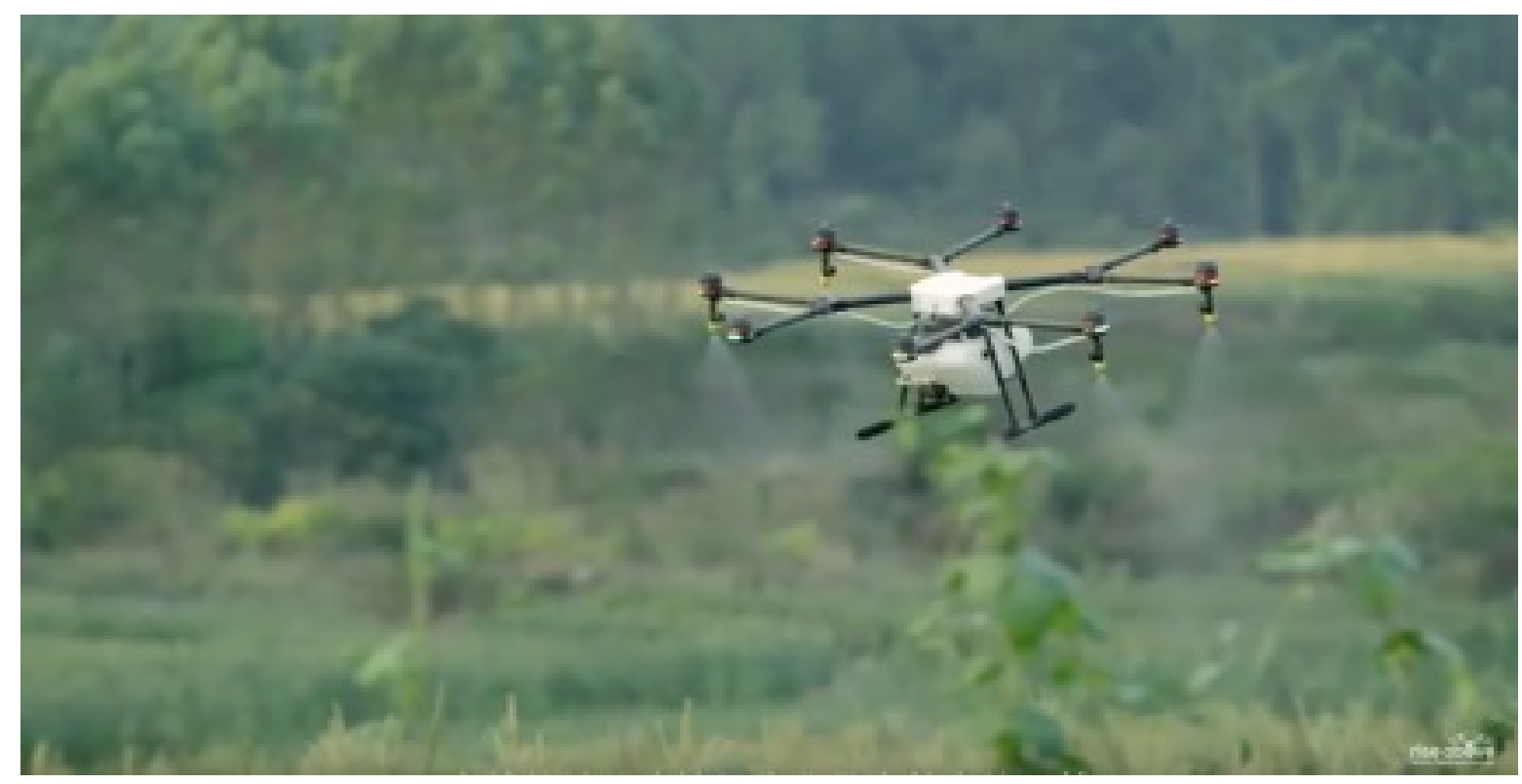

Figuur 16 DJI Agras Agricultural Drone (bron: YouTube 26-NOV-2015).

In Nederland wordt ook gewerkt aan een grotere landbouwdrone van een andere orde. Het bedrijf Drone4Agro ontwikkelt een drone die tot $100 \mathrm{~kg}$ mee kan nemen (Figuur 17), onder andere een complete sproei-installatie, gereedschappen of materialen.

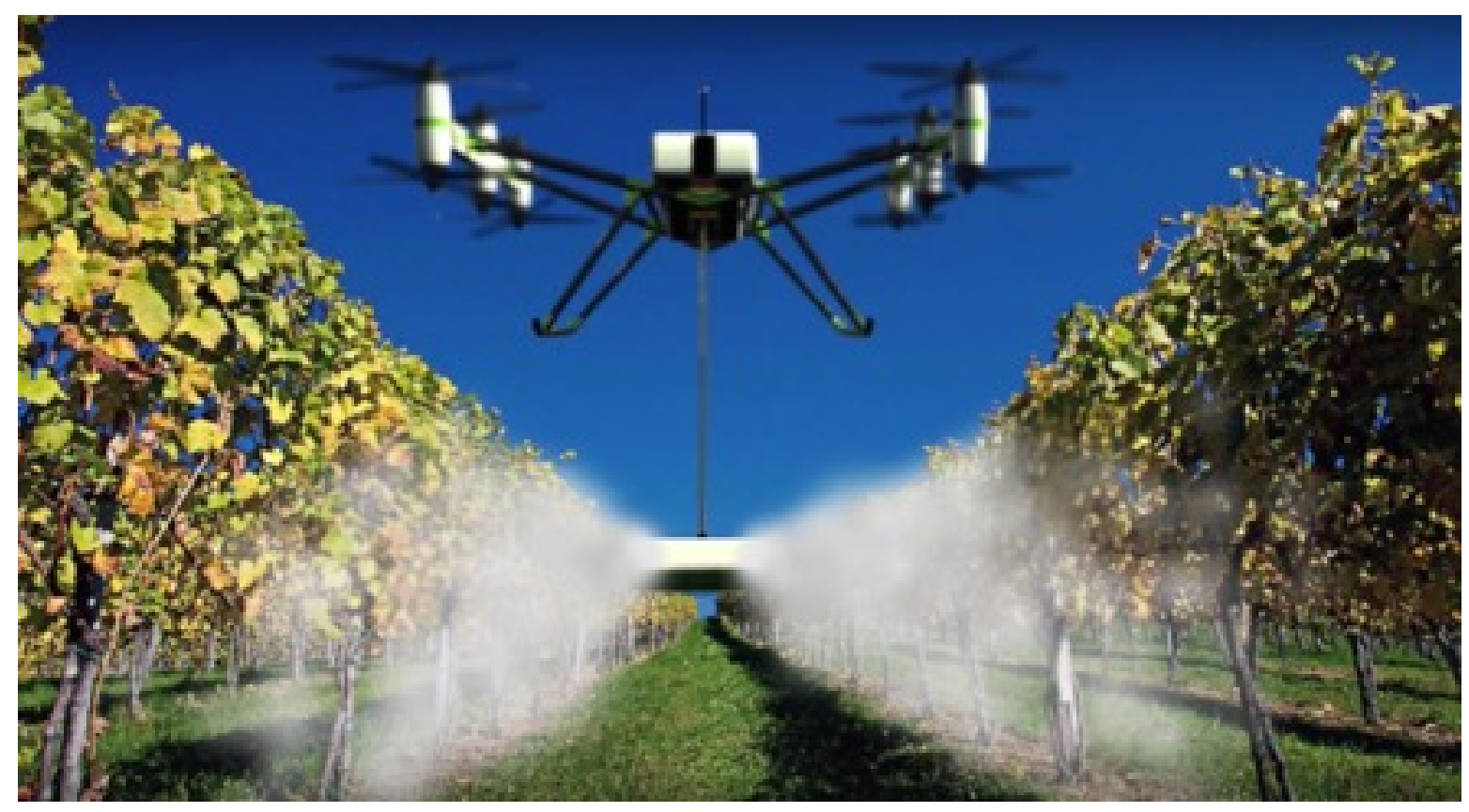

Figuur 17 'Het vliegende werkpaard' van Drone4Agro. Een onbemand platform dat $100 \mathrm{~kg}$ aan payload kan tillen (bron: YouTube / Drone4Agro).

Een andere toepassing is het gebruik van drones als sensor voor bodemvocht. Een groep bedrijven en instellingen werkt samen om zo'n Soil Moisture Mapping drone op de markt te krijgen in het project 
mistrale.eu. De sensor aan boord van de drone maakt gebruik van op de bodem gereflecteerde GNSSsignalen van bv. gps of GALILEO (Figuur 18). Het karteren van bodemvocht en -verschillen geeft informatie over waterbehoefte (beregening) of over de berijdbaarheid van de akker.

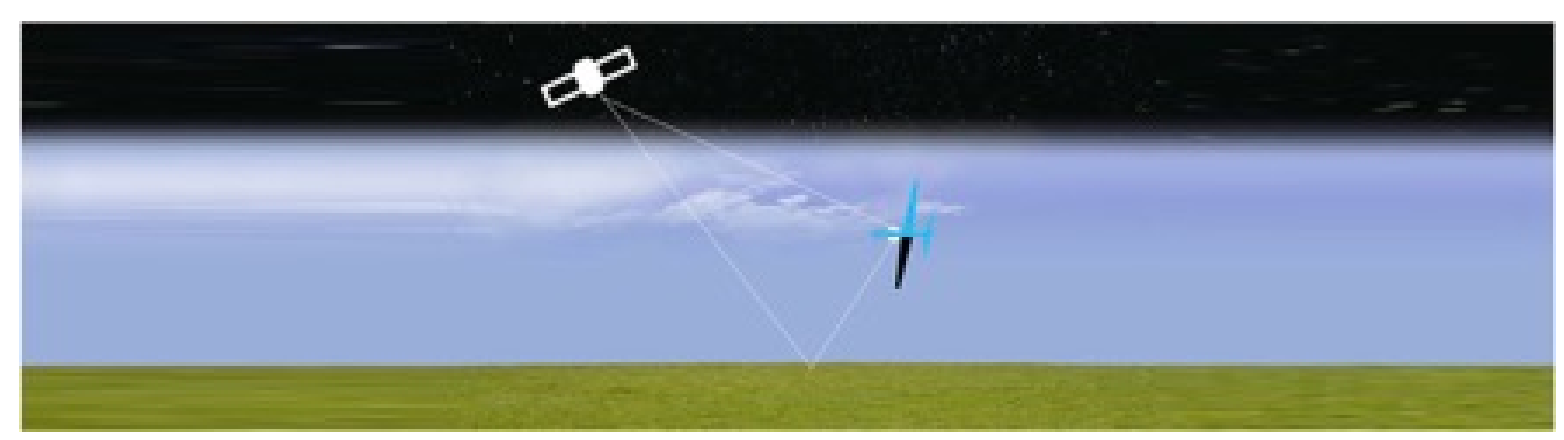

Figuur 18 Een soil moisture mapping drone maakt gebruik van zgn. reflective-GNSS (bron: www.mistrale.eu).

\subsubsection{Voorbeelden in de veehouderij}

Er zijn enkele onderzoeksprojecten waar drones toegepast worden voor veehouderij. Het gaat daarbij voornamelijk om het opsporen/inspecteren van de kudde en dieren. Een andere toepassing is om de drone als schaapshond in te zetten (Figuur 9).

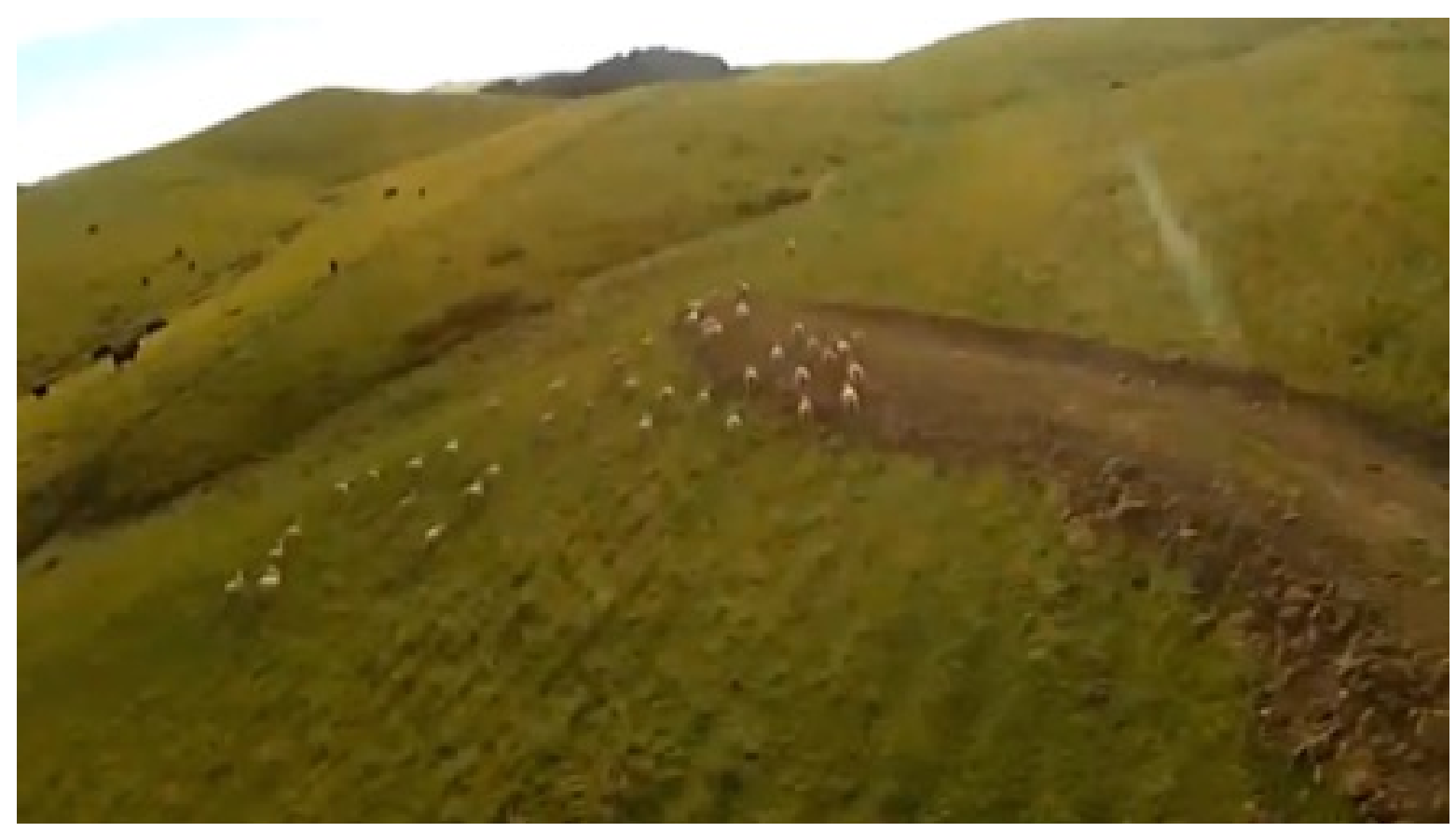

Figuur 19 Een still uit de realtime video van een herdersdrone uit Nieuw-Zeeland. De drone drijft in dit geval schapen in de gewenste richting (bron: YouTube).

\subsubsection{Toepassingen voor handhaving door overheden}

De bovenstaande en andere toepassingen, met name die gericht zijn op monitoring, maken duidelijk dat drones ook ingezet kunnen worden op handhaving. In de praktijk gebeurt dit nog niet. De NVWA experimenteert momenteel wel met satellietbeelden ter ondersteuning van haar handhavingstaken op landbouw- en natuurbeleidsterreinen. Een verlengstuk daarvan kan de inzet van drones zijn. Een interessante toepassing is de snelle kartering in 3D met behulp van drones waarmee gewasgrenzen 
snel en nauwkeurig ingewonnen kunnen worden (ook onder overhangende bomen en langs sloten) en tevens zgn. non-compliance kan worden geregistreerd (bv. land niet in goede landbouw- en milieuconditie (GLMC) - een van de randvoorwaarden van het GLB). Dit zou de ter-plaatse-controle van NVWA-inspecteurs kunnen versnellen. Een ander alternatieve toepassing is om NVWA-inspecteurs met een 'hover bike' te vervoeren zodat zij op efficiënte wijze het bedrijf kunnen inspecteren (Figuur 20).

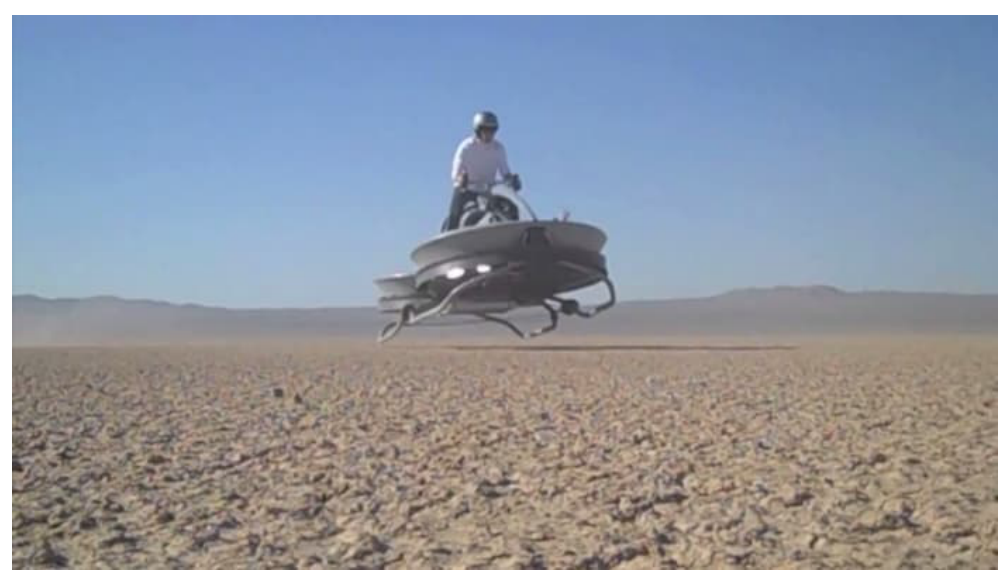

Figuur 20 'Hover-bike' van AeroFex (www.aerofex.com).

Veel waterschappen overwegen drones in te zetten, bijvoorbeeld om dijken te inspecteren of lastig toegankelijke gebieden in te meten. De toepassing van dergelijke luchtvoertuigen heeft zeker voordelen: ze werken snel en efficiënt, zijn relatief goedkoop in te zetten en kunnen een schat aan (aanvullende) gegevens opleveren.

\subsubsection{Indoor}

Ook in de glastuinbouw zijn er steeds meer toepassingen te vinden. Met behulp van drones is het bijvoorbeeld mogelijk om op vrijwel elke locatie in de kas metingen uit te voeren op basis waarvan het klimaat beheerst en gewassen gemonitord kunnen worden (Roldan et al., 2015) (Figuur 21 en 22).

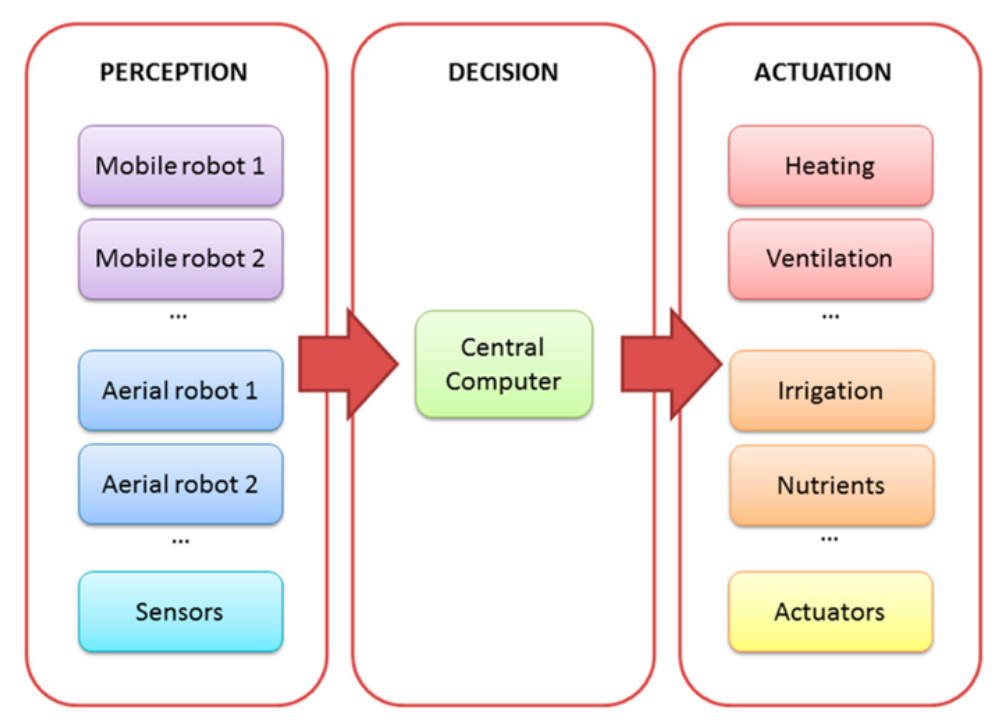

Figuur 21 Schematische weergave van inzet drones in kassen. 


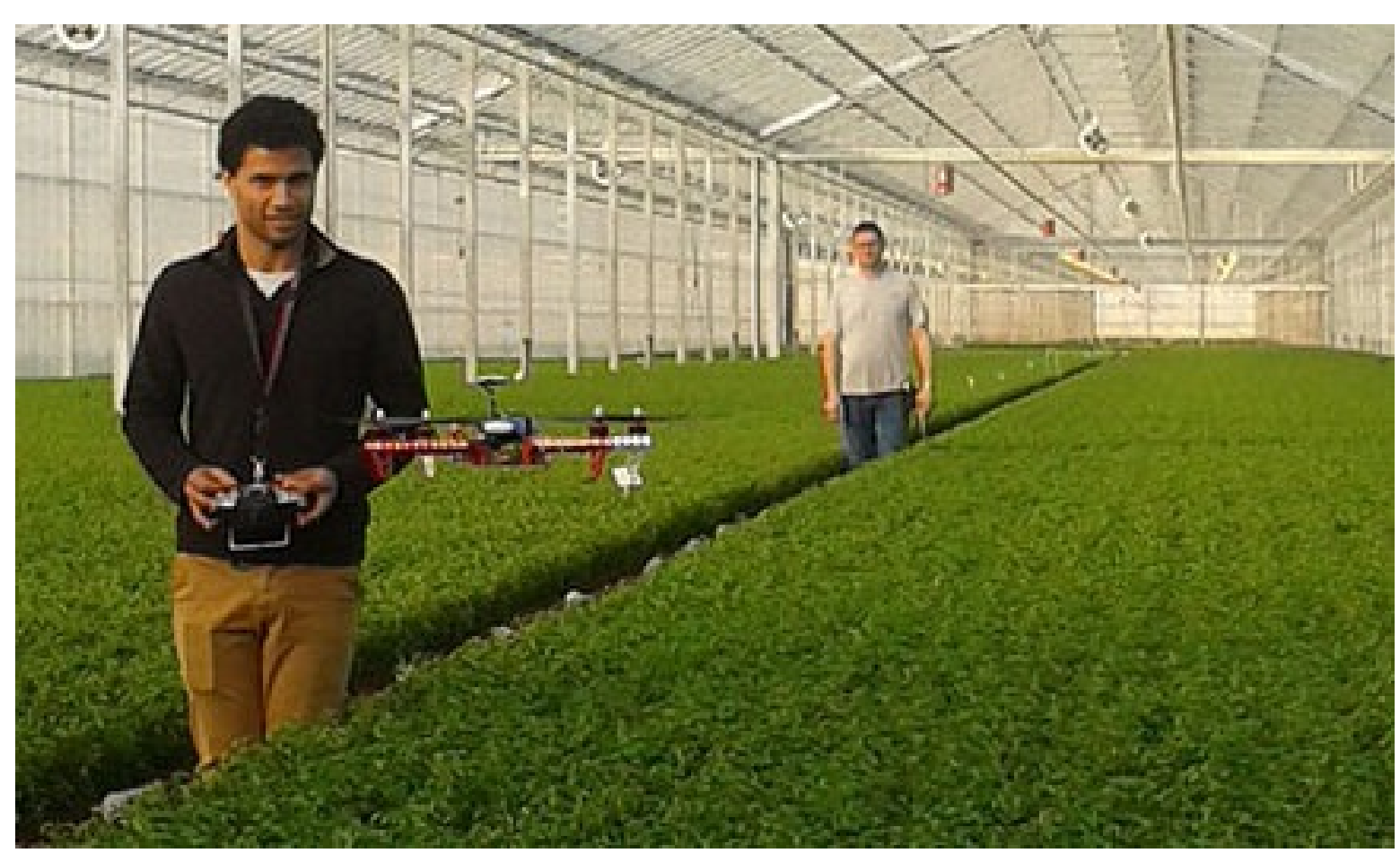

Figuur 22 Drone-experiment in een kas voor inspectie van het gewas (bron: scienceguide / InHolland Delft).

\subsubsection{Adoptiebarrières in de landbouw}

Zoals hiervoor aangegeven, verwachten verschillende marktvoorspellingen veel van de inzet van drones in de landbouw. De werkelijke commerciële doorbraak is echter nog niet geweest. Daar kunnen meerdere redenen voor zijn:

1. wet- en regelgeving weerhoudt boeren en hun adviseurs/dienstverleners ervan om op grotere schaal drones toe te passen omdat de wet voor ieder commercieel gebruik (dus ook op het eigen bedrijf) een brevet vereist.

2. De tweede, wellicht belangrijkere, reden is dat de vertaling van camera- of sensorbeeld naar toediening niet eenduidig is en nog te veel eigen interpretatie vereist. Ondanks het vele onderzoek naar gebruik en interpretatie van Remote Sensing-beelden is het nog geen gemeengoed om een droneopname daadwerkelijk geautomatiseerd te verwerken tot bijvoorbeeld een kaart met strooiintensiteiten voor kunstmest. Voor de vliegende spuit kan opgemerkt worden dat naast luchtvaartregelgeving ook de milieuwetgeving rondom drift eisen stelt aan toepassingen met drones en waarvan momenteel de nakoming nog aangetoond moet worden.

Vanuit de precisielandbouw zijn nog andere adoptiebarrières bekend. Zo investeren boeren niet in gps of andere precisielandbouwtechnologie als niet duidelijk is hoe de kosten en opbrengsten zich tot elkaar verhouden. Kennis is een andere barrière. Voor drones betekent dit onder andere ook dat de opleiding tot piloot onderdeel is van de kennisvergaring (in ieder geval zolang er geen autonome drones toegelaten zijn). Bovendien zijn de kosten voor het halen van diploma's en licenties nogal hoog. Dit wordt door de geïnterviewde ondernemers onderstreept.

Een overheid die geïnteresseerd is om deze technologie breed ingezet te krijgen, bijvoorbeeld omdat het bepaalde overheidsdoelen steunt, kan werken aan deze barrières. Het creëren van toegankelijke opleidingen is bijvoorbeeld een overheid gerelateerde mogelijkheid om aan te werken.

Ook kan de overheid een experimenteerruimte creëren, in de geest van de Living Labs of FieldLabs, waarin de technologie de ruimte krijgt. Voor de ontwikkeling van drones in de landbouw zou daarvoor een substantieel landbouwgebied als 'dronezone' bestempeld kunnen worden om daar ondernemers uit te dagen de innovaties te tonen in een werkelijke setting met boeren. Onderdeel van zo'n dronezone moet ook de maatschappelijke discussie over wenselijkheid zijn en de ethische aspecten van drones moeten daarbij eveneens aan bod komen. 
Een mogelijke rol voor het bedrijfsleven is om een dronecalculator op de markt te brengen: een rekentool waarmee snel inzichtelijk wordt wat een dronebeeld kost en hoe dat terugverdiend kan worden in de rest van de dagelijkse operatie. Dergelijke calculators zijn er ook voor melkrobots en precisielandbouwmachines.

\subsection{Gebruik in de natuur}

\subsubsection{Drijfveren}

De mogelijkheden van drones zijn niet aan de actoren in de natuur voorbijgegaan en er zijn diverse ondernemers actief met drones voor natuur. Een bijeenkomst van InnovatieNetwerk Agro \& Natuur in mei 2016 liet verschillende ondernemers aan het woord die actief zijn met drones en nog veel meer mogelijkheden. Deze bijeenkomst werd ondersteund met een verkenning over toepassingen van drones in de natuur (Joziasse en Op de Beek, 2016). Uit het rapport en tijdens de bijeenkomst werd duidelijk dat de meeste toepassingen in het gebruik op het gebied van beheer en handhaving liggen. De drijfveer voor natuurbeheerders is vooral efficiëntere monitoring. Daarnaast voorziet men mogelijkheden voor handhaving van o.a. gebruiksbeperkingen en specifieke opsporingstaken zoals van verdwaalde kinderen. Alhoewel er interessante businessproposities gedaan zijn voor commerciële ondersteuning van de exploitatie van bos en natuur - zoals de 'drone butler' die koffie brengt aan wandelaars (zie Figuur 23) of het vergunnen van het luchtruim voor het maken van natuurfilms wordt dit niet als een kortetermijndrijfveer voor dronestoepassingen gezien.

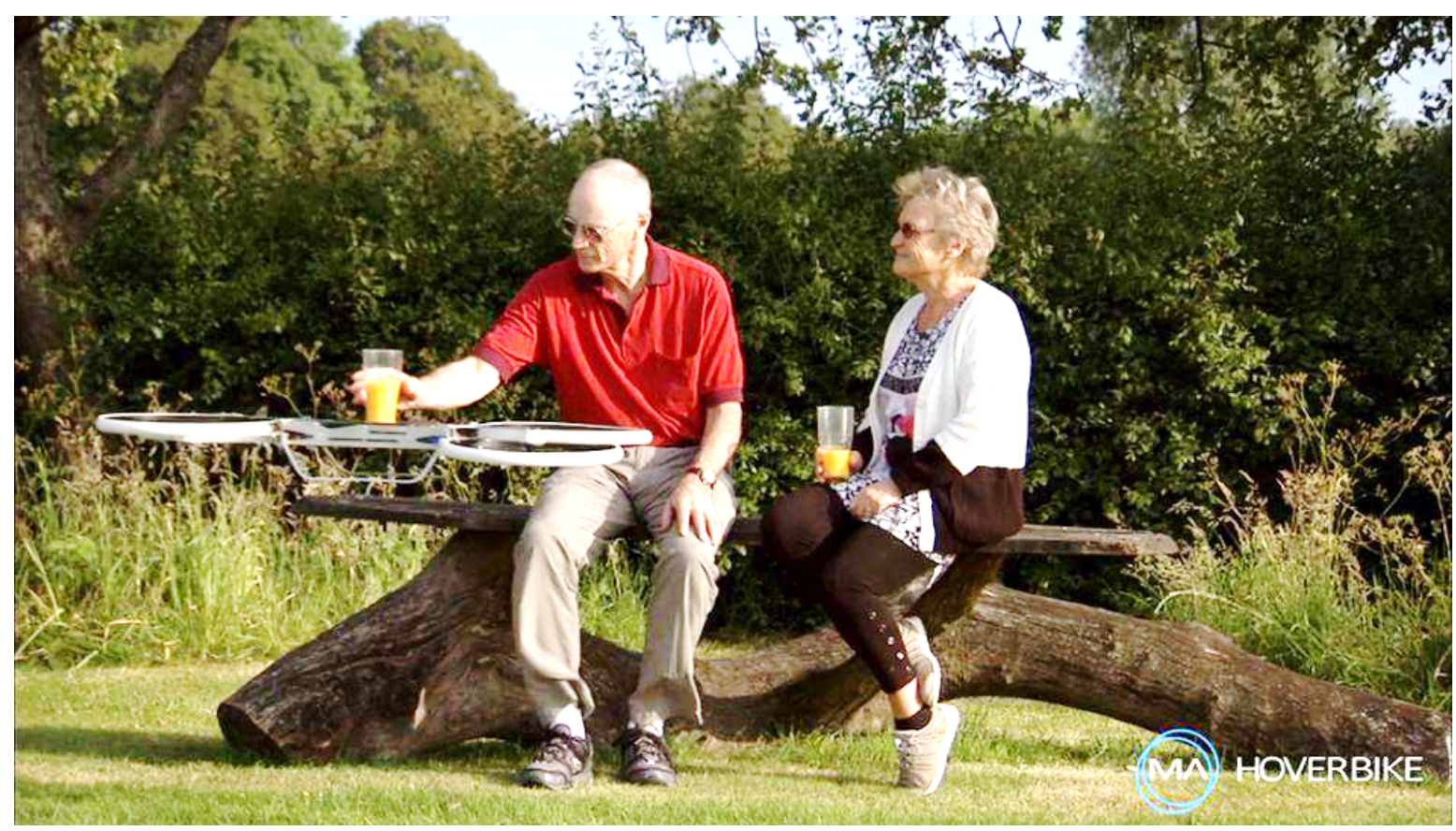

Figuur 23 Drone3 van Malloy Aeronautics (overgenomen uit rapport Zuivere Speeltijd).

Natuurbeheerders zijn geïnteresseerd in de mogelijkheden van drones, met name als het besparingen in tijd en uitvoeringskosten van het beheer kan opleveren. Daarnaast wordt het natuurbeheer ook steeds meer data-gedreven en drones kunnen een bijdrage leveren in het verkrijgen van gegevens over natuurterreinen, analoog aan het gebruik in de landbouw.

Net als in de landbouw kan de drone ook in de natuur een belangrijke bijdrage leveren aan het beheer ervan door taken eenvoudiger of rendabeler uitvoerbaar te maken. Hierbij is met name het gebruik van drones ten opzichte van het alternatief een groot voordeel: zo kunnen anders minder makkelijk bereikbare plekken in natuurgebieden met drones worden bezocht, bijvoorbeeld voor het tellen van nesten tussen bomen of het nemen van watermonsters midden in een meer. Een groot voordeel ten 
opzichte van andere luchtvaartuigen is dat drones minder lawaai/verstoring veroorzaken dan bijvoorbeeld een bemande helikopter.

In een recente verkenning wordt ook gekeken of drones mensen dichter bij de natuur kunnen betrekken en hoe er met dronegebruik door of voor bezoekers ook omzet gemaakt kan worden. Hierbij wordt gedacht aan natuurgames met drones, het opsporen van verdwaalde kinderen of het bezorgen van versnaperingen of levensreddende middelen (Joziasse en Op de Beek, 2016).

De natuur biedt ook een natuurlijke arena voor droneracers en recreatieve vliegers. Dit is geen 'natuur drijfveer', eerder een drijfveer van de natuurbelever, vergelijkbaar met mountainbiken. Het levert ook een dilemma op, want natuurbeleving mag (moet!), maar overlast of schade moet worden beperkt of uitgebannen. Behalve het verbieden van drones in natuurgebieden is het denkbaar dat er ook natuurbanen komen voor recreatieve droneracers (Figuur 27).

\subsubsection{Voorbeelden in de natur}

De toepassingen in de natuur zijn niet veel anders dan in de landbouw: met name het maken van beeldmateriaal (al dan niet multispectraal, oblique/stereo (vegetatiehoogte), thermisch of met radar, LiDAR etc.) voor karteringen en monitoring heeft veel overeenkomsten met de landbouw. Nuttige toepassingen zijn bijvoorbeeld het tellen van nesten of dieren (Figuur 25, Figuur 26). Hierbij worden drones ingezet met elektromotoren, zodat ze relatief stil zijn en de dieren niet wegjagen. Drones vormen een goed hulpmiddel bij het opsporen van stropers of bosbranden.

Voor bijvoorbeeld het in kaart brengen van terreinen en het bossen hebben drones zich reeds bewezen (Jones et al., 2006; Hodgson et al., 2013). Kenmerkend voor dit soort toepassingen is dat een realtime verwerking van data niet per se noodzakelijk is. Voor de bescherming van dieren tegen bijvoorbeeld stropen is een realtime verwerking wel cruciaal. Maar de technieken om mensen en dieren te detecteren met behulp van beperkte rekenkracht is op dit moment nog niet beschikbaar voor realtime toepassingen (Van Gemert et al., 2014).

Van een andere orde is het maken van natuurfilms met behulp van drones. Dit is iets voor professionals én amateurs. Met name het privégebruik van drones levert voor natuurorganisaties soms wel problemen op, omdat men zich vaak niet bewust is van wat er mag en wat er voor risico's aan verbonden zijn. De FAA waarschuwt mensen om niet met een drone naar Washington te komen voor het Cherry blossom festival (Figuur 24).

\section{ENJOY THE NATIONAL CHERRY BLOSSOM FESTIVAL LEAVE YOUR DRONE AT HOME}

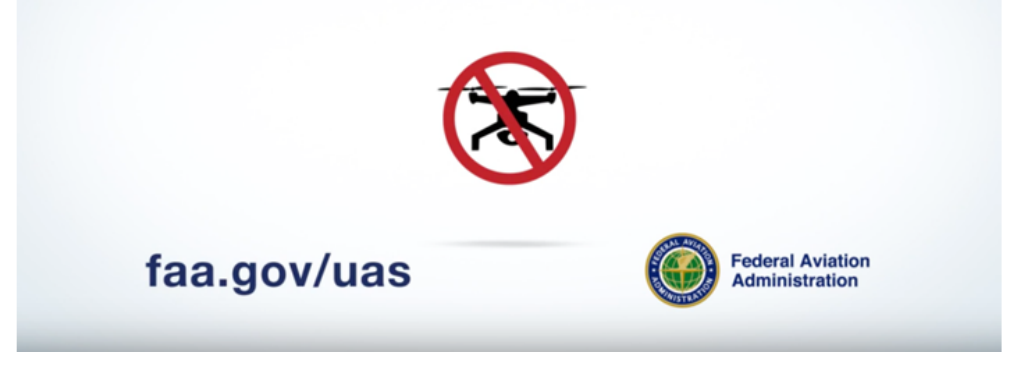

Figuur 24 Aankondiging van de FAA dat het jaarlijkse Cherry blossom festival geen toegang biedt aan drones. (bron: www.faa.gov/tv). 

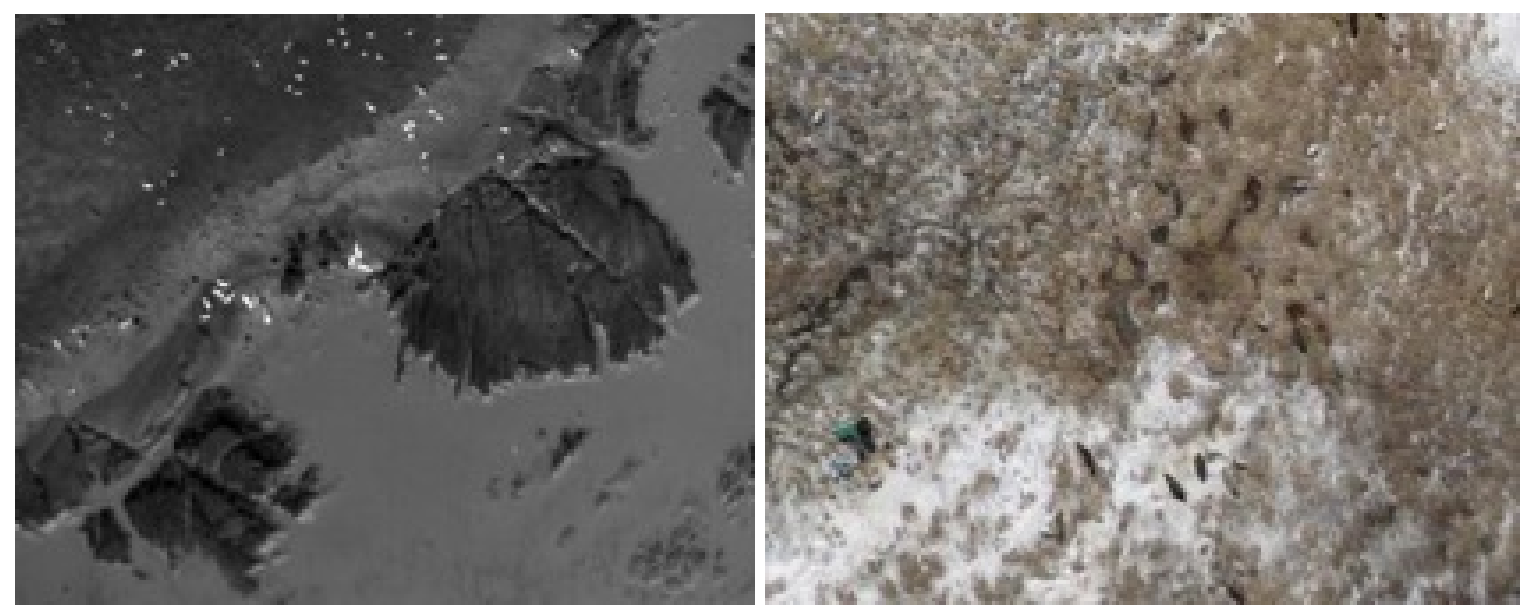

Figuur 25 Zeehonden tellen op een drone luchtfoto. Links optisch, rechts thermisch (bron: suasnews.com / Duke University).
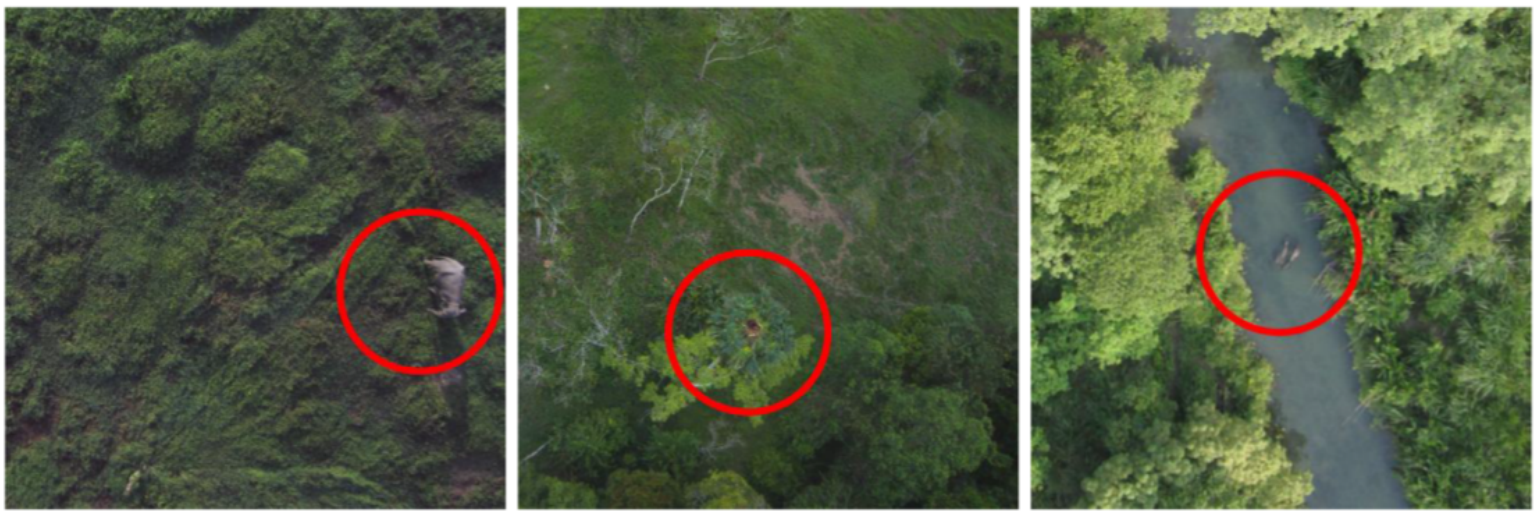

Figuur 26 Het lokaliseren en monitoren van dieren. Van links naar rechts een olifant, een nest en een neushoorn (bron: Van Gemert et al., 2014).

In de natuur kan er ook een recreatieve waarde zijn van drones (bijv. fotowedstrijden of droneraces).
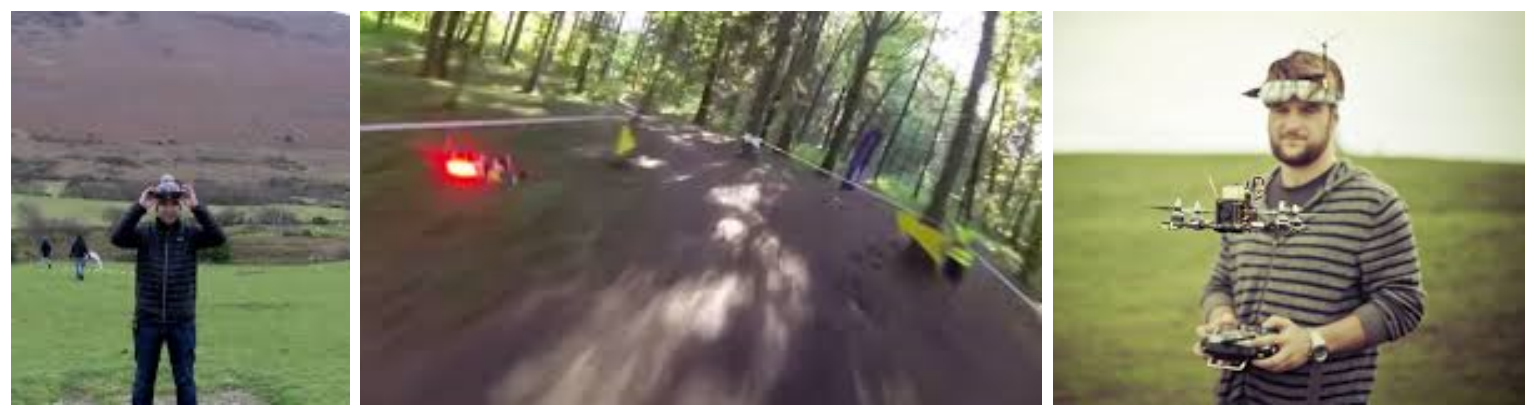

Figuur 27 Illustratie van droneraces in de natuur.

\subsection{Technologische ontwikkeling}

De technologische ontwikkeling gaat inmiddels door. Universiteiten, onderzoeksinstellingen en bedrijven investeren in R\&D in eigenlijk alle aspecten van de drone. Aan de technologische kant gaat het onder andere om de aerodynamica en elektronische componenten die de drone, sterker (grotere 
Take Off Weight) en veiliger maken. Verder wordt er gewerkt aan mechatronica en kunstmatige intelligentie om de autonomie te versterken. Dit betreft ook de zogenaamde Sense\&Avoid-systemen waarmee drones zelfstandig obstakels in het luchtruim (incl. andere drones/vliegtuigen) kunnen ontwijken.

Er wordt verder ook heel hard gewerkt en geïnnoveerd aan de payloads: camerasystemen voor recreatieve doeleinden vragen om betere kwaliteit. Professionele camera's worden verder geminiaturiseerd voor vele diverse doeleinden, van filmindustrie tot leidingeninspectie. Maar ook landbouwspuiten, robotarmen e.a. apparaten waarmee de drone een veelzijdig platform wordt.

De meest in het oog springende trends zijn:

- In navolging van het Japanse Yamaha werken droneontwikkelaars aan sproei- en spuitmogelijkheden. Het wordt daarmee mogelijk om op moeilijk berijdbare akkers toch te spuiten en om eenvoudig specifieke plekken aan te doen (zonder met een grote machine het veld in te moeten).

- De gangbare elektronica concerns, zoals de Japanse bedrijven NEC, Fujitsu en Sony, betreden de dronemarkt en zijn geïnteresseerd in de (massa)productie van chips en andere elektronicacomponenten. De Japanse bedrijven richten zich vooral op autonomie en veiligheid. Het Amerikaanse elektronicabedrijf Intel laat zich niet onbetuigd met de Realsense camera en bijbehorende chip. Ook NVIDIA en Qualcomm werken aan specifieke chipsets voor drones.

- Software-platformen voor de landbouw, zoals ConnectedFarm, MyJohnDeere, 365farmnet en de Nederlandse Crop-R en Akkerweb werken mogelijkheden uit om dronedata (naast bodemscans en satellietbeelden) te integreren in de bedrijfsmanagementsystemen die zij voor boeren ontwikkelen. Daarmee worden de ontsluiting en toepassing aanzienlijk eenvoudiger.

- Payload-ontwikkelaars uit de ruimtevaart en onderzoekers van satellietbeelden verplaatsen hun aandacht naar de sterk groeiende dronemarkt. Hiermee nemen de slagkracht en potentie van drones voor bijvoorbeeld Remote Sensing enorm toe. Hyperspectraalcamera's, thermische camera's en nog vele andere type sensoren zorgen voor nieuwe mogelijkheden of haalbaarheid.

- Landbouw wordt nog steeds gezien als de belangrijkste afnemer van drones. Nieuwe schattingen zijn dat de landbouw goed is voor 3.7 miljard dollar in $2022^{10}$. Investeerders laten zich niet afleiden door de schaarse, echt operationele commerciële toepassingen en hebben volgens hetzelfde bericht in 2015 voor 350 miljoen dollar geïnvesteerd in 37 landbouwgerelateerde drone start-ups.

Een andere belangrijke trend zijn de ontwikkelingen in de regelgeving. Regelgeving is inherent reactief op de technologische mogelijkheden en zal zich moeten ontwikkelen tot een stabiele randvoorwaarde teneinde een level playing field voor droneontwikkelaars en operators te geven. Op termijn zal de regelgeving voor professioneel gebruik ruimte bieden voor economische ontwikkeling en borging van veiligheidsaspecten e.a., getuige de nu al de ingevoerde RPAS Operator Certicificate Light $^{11}$ en de gepresenteerde beleidsvoornemens van de Europese Commissie.

\subsection{Verwachtingen en belemmeringen}

De interesse van ICT-bedrijven voor de grootschalige productie van drones en payloads zal er voor zorgen dat drones goedkoper en beter kunnen worden. De specialisaties voor allerlei taken, zoals voor landbouw, zullen toenemen. Landbouw is een aantrekkelijke markt vanwege de vele bedrijven die er opereren en die interesse of behoefte hebben aan de mogelijkheden van drones om diverse redenen zoals in dit rapport aangevoerd. De professionele markt voor natuur en natuurbeheerders is veel kleiner. Natuurbeheerders aarzelen ook nog om de drones in te zetten vanwege verstoringseffecten en het geven van een verkeerd voorbeeld wanneer het de bezoekers wel dronesgebruik verbiedt.

Het is nauwelijks voorstelbaar, maar als dadelijk iedere boer (of adviseur) en boswachter (of ecoloog, of recreant) met drones gaat vliegen, dan wordt het druk in het luchtruim. Aan de andere kant:

\footnotetext{
10 https://agfundernews.com/ag-drones-market-to-reach-3-7bn-by-2022-as-cropio-first-to-integrate-drones-with-satelliteimagery5648.html

11 https://www.rijksoverheid.nl/onderwerpen/drone/vraag-en-antwoord/vergunning-drone
} 
landbouw en natuur zijn grootgrondbezitters (of -gebruikers) waarvoor geldt dat zij die drukte boven het eigen terrein redelijk zouden moeten kunnen regelen. Maar wat gebeurt er op de randen tussen landbouw en stad? En hoe steekt een landbouwdrone de (snel)weg over? Ondernemer Winfried Rijssenbeek werkt aan triple redundant-systemen zoals gebruikelijk in de vliegtuigbouw waarmee veiligheid kan worden geborgd.

Zoals al gezegd, is de elektronica-industrie zeer geïnteresseerd in drones als nieuwe afzetmarkt van hoogwaardige chips. Naast de navigatiesystemen en communicatie zijn ook de sense-and-avoid systemen een complex van sensoren en actuatoren. De verwachting is dat met innovatieve botspreventie de drones beter in staat zullen zijn elkaar en andere objecten te mijden. De drukte in het luchtruim is dan geen probleem meer (?) Dit vraagt onherroepelijk om allerlei nieuwe oplossingen voor problemen die we nog niet goed kunnen voorzien, maar de discussies rond de autonome auto en de wenselijkheid daarvan zijn een aardige voorbode over wat we met drones mogen verwachten. Vooralsnog zijn vragen over een toenemend aantal drones die steeds meer autonoom kunnen opereren nog niet aan de orde. De huidige generatie drones, toch van een wat 'dommer' allooi, zal alleen autonoom kunnen vliegen in een nagenoeg gegarandeerd exclusief luchtruim. De behoefte aan zo'n exclusief stuk luchtruim, een zgn. flight enveloppe, of "blok-lucht reservering" en een dynamisch registratiesysteem van reeds in gebruik zijnde blokken lucht, zou zo'n invulling kunnen geven. Projecten van de Europese GNSS Agency (GSA) hebben laten zien dat met behulp van de Europese civiele satellietnavigatiesystemen Galileo en EGNOS een dergelijke methode in de vorm van 'geofencing' en een virtual flight enveloppe denkbaar is. Dit vereist natuurlijk wel dat de satellietnavigatie onverstoorbaar werkt (of een achtervang heeft, zoals de genoemde triple redundancy). In hetzelfde stramien zijn tunnel-corridors denkbaar die drones door risicovolle zones leiden, zoals snelwegen of woonwijken. Het is daarmee een vertaling van het werk van de luchtverkeersleider naar een computersysteem. Dit vereist op zichzelf weer veel communicatie en ook hierin is de computerindustrie geïnteresseerd.

Het voorkomen van crashes is een complex geheel waar techniek, omgeving, piloot etc. een rol in spelen. Instructies, opleiding en handhaving op de piloot zijn belangrijke basisrandvoorwaarden om een veilig gebruik te garanderen. Technische beperkingen aanbrengen kan daarbij helpen. Hoogte begrenzers en virtual fences zijn mogelijke oplossingen. Een op afstand over te nemen besturing door handhavers zou ook een mogelijkheid zijn. Het grote voordeel van landbouw en natuur is dat de kans dat crashes tot lichamelijk letsel leiden kleiner zijn dan in de stad. Ook is de kans kleiner op omvangrijke schade aan goederen als gevolg van een crash.

De massaproductie van drones brengt weer nieuwe aspecten van de industrie in deze sector. De vliegtuigindustrie kent een uitgebreid protocol van onderhoud en van analyse van (bijna-)crashes. Voor de drones zal de 'terugroepregeling' zoals bij auto's waarschijnlijk dichter bij de werkelijkheid komen. Ook zullen de dronebouwers en distributeurs een netwerk van onderhoudsbedrijven moeten opzetten als de landbouw inderdaad zo'n grootgebruiker van drones gaat worden.

\subsection{Maatschappelijke vraagstukken als (toekomstige) drijfveren}

De belangrijkste thema's in de landbouw en natuur, die in de vorm van maatschappelijke vraagstukken dienen als drijfveren, zijn:

- Productiviteitsverhoging: de landbouw zoekt collectief en individueel naar methoden waar de productiviteit van toeneemt. De precisielandbouw is daar ook uit voortgekomen: dezelfde opbrengst met minder input, of meer opbrengst per eenheid input. En die eenheid kan zijn arbeid, een liter brandstof, een liter water, een kilo kunstmest etc. Een belangrijke nuance tegenwoordig is dat de productiviteit niet alleen in kilo's product wordt gemeten, maar steeds meer als economisch rendement. Zo kunnen bepaalde precisielandbouwmethoden leiden naar een lagere fysieke opbrengst, maar door lagere kosten leiden naar een hogere marge.

- Milieuregels: de afgelopen decennia is het besef gegroeid dat duurzaamheid en vergroening een noodzaak zijn, wat onder andere bevestigd is in wet- en regelgeving. Ook op het gebied van broeikasgassen zal de landbouw maatregelen moeten verwachten. Om de emissies van landbouw te meten en om daar ook concreet wat aan te doen, is informatie nodig. Drones met allerlei sensoren kunnen daar een belangrijke bijdrage aan leveren. Een voorbeeld zijn de mestregels. De 
aanwending van mest is gemaximeerd en met behulp van gewasopnames door drones wordt de verdeling van mest zodanig gestuurd dat deze maximale hoeveelheid optimaal wordt ingezet.

- Bodemverdichting: een belangrijk thema in de akkerbouw is momenteel bodemverdichting als gevolg van zware machines. Drones als 'werkpaard' zijn een mogelijk alternatief waarbij 'contactloos' het land en het gewas bewerkt kunnen worden. Met name de veelvuldige bespuitingen in gewassen kunnen door drones worden uitgevoerd en daarmee het aantal keren berijden van het land drastisch worden teruggebracht.

- Dataficatie van landbouw en natuur: wellicht een nog onderschat thema, maar voor de toekomst een niet te missen aspect is de behoefte aan data over de actuele stand van zaken op het bedrijf. De bedrijfsvoering in de landbouw en in natuurbeheer wordt steeds meer afhankelijk van kwalitatieve inputdata. Toenemende automatisering en robotisering vraagt om extra databronnen die computers, modellen en machines voeden om met behulp van slimme algoritmen steeds meer autonoom delen van de bedrijfsvoering over te nemen. Het zgn. Internet of Things zorgt voor grotere connectiviteit en samenwerking tussen allerlei componenten. Remote Sensing met drones in aanvulling op alle andere bronnen en sensoren is een onvermijdelijk toekomstperspectief.

Deze maatschappelijke thema's voor drones lijken erg op die van precisielandbouw en drones zijn waarschijnlijk vooral in die context te plaatsen. Immers, precisielandbouw is een hoogtechnologische innovatie voor de landbouwpraktijk en drones maken daar onderdeel van uit.

Voor natuur zijn dergelijke thema's ook geldig, maar natuurlijk iets anders in te vullen. Voor veel terreinbeheerders zal vooral het 'big data'-aspect een belangrijk thema vormen: efficiëntere inventarisaties van flora en fauna. Ook een bijdrage aan toezicht houden op naleving van regels in natuurgebieden kan met drones efficiënter worden. En natuurlijk vormen drones een directe bron van situational awareness bij het voorkomen of beheersen van bosbranden, overstromingen, droogte etc. Recreatief gebruik zal ook voor natuur een rol spelen, alhoewel daarin geen drijfveer voor de natuurbeheerder schuilt, eerder voor de consument of recreant. Het faciliteren van recreatief gebruik van drones in de natuur kan wel bijdragen aan het vergroten van natuurbeleving (natuurfilms bv.) en gebruik van de natuur (dronesraces, vergelijk met mountainbikes). De balans met verstoring en overlast is in zulke gebieden natuurlijk makkelijk verstoord. 


\section{Beleidsaspecten}

\subsection{Maatschappelijke vraagstukken als (toekomstige) drijfveren}

\subsubsection{Duurzame landbouw}

Precisielandbouw of 'Smart Farming' is een belangrijke drijfveer voor de inzet van drones en andere innovaties. Niet alleen voor de aanbieders van drones en haar componenten, maar ook voor de gebruikers zoals de boer en zijn dienstverleners. Daarbij dient precisielandbouw ook maatschappelijke doelen. Met het totaal aan precisielandbouwtechnieken is de verwachting dat daarmee een besparing van zo'n 15-30\% aan middelen gerealiseerd kan worden zonder de productie negatief te beïnvloeden. Daarmee verdwijnt ook de 'overdosis' aan middelen die anders in het milieu terechtkomt. De inzet van drones biedt dus een win-win voor de portemonnee en het milieu en maakt het de moeite waard om ze in de toekomst meer in de landbouw in te zetten.

De inzet van drones als vliegende tractors heeft als positief bijeffect dat het de bodem niet samendrukt. Hiermee verandert de balans tussen bijvoorbeeld een extra uitgifte van kunstmest en het daarmee veroorzaakte structuurbederf. De inzet van drones leidt tot een verstandiger mestregime. Tot op zekere hoogte geldt dit ook voor gewasbescherming. Echter, wel/niet spuiten is hierbij niet een economische keuze, omdat bij niet spuiten het verlies van de hele oogst op het spel staat. In Nederland is het spuiten met vliegtuigen, helikopters en drones beperkt vanwege de regelgeving rondom drift.

\subsubsection{Beter natuurbeheer}

Een dronesproef in 2011 liet zien dat met de juiste resolutie en het juiste opnametijdstip bepaalde gidsplantjes in de vegetatie gekarteerd kunnen worden. Drones bieden daarmee een extra mogelijkheid voor de ecoloog om snel en effectief vegetatie in kaart te brengen. Dit kan bijdragen aan het monitoren van natuurdoelen en om bepaalde aspecten van natuurbeheer ook beter ruimtelijk expliciet te maken, waardoor bijvoorbeeld oorzaak-gevolg van maatregelen goed zichtbaar wordt. Andere voorbeelden zijn het tellen van nesten in een lepelaarskolonie wat met een drone vanuit de lucht aanzienlijk beter gaat en met minder verstoring voor de vogels dan met een bootje een teller in de kolonie afzetten, het nemen van watermonsters uit een plas of het tellen van bezoekers.

Kortom, de inzet van drones kan voor de natuurbeheerder een belangrijk instrument worden. De eisen die aan de technologie gesteld worden, kunnen aanzienlijk anders zijn dan bij de landbouw.

Bijvoorbeeld voor het tellen van dieren zal een langere verblijftijd op dezelfde plek wenselijk zijn dan voor het fotograferen van een akker.

\subsubsection{Handhaving}

De NVWA komt bij boeren op het erf en verricht dan tal van inspecties/controles. Het is niet geheel ondenkbaar dat in de nabije toekomst de inspecteur zijn bezoek begint met het vliegen van een drone om een betere situational awareness te krijgen en ook plekken uit te sluiten van een bezoek omdat het er gewoon goed uitziet. Maar het dronebeeld kan ook juist aanleiding zijn voor inspectie. De in hoofdstuk 2 genoemde voorbeelden zijn ook allemaal als handhavingsvarianten te zien. En in deze sector is de conceptuele overlap met politie, brandweer of beveiliging snel gevonden. NVWA kan derhalve als launching customer wellicht een betere handhaver worden, omdat inspecties sneller gaan en objectief beeldmateriaal opleveren.

Een mogelijk alternatief is dat de NVWA-inspecteur de dronebeelden van de boer opvraagt om daar zijn inspecties op te plegen. Dat zou een nieuwe vorm van handhaving zijn. 


\subsubsection{Werkgelegenheid}

Landbouw wordt door velen gezien als de grootste afzetmarkt voor drones. Door de verschillende toepassingen ontstaat er nieuwe werkgelegenheid bij de ontwikkeling en bouw van drones en bij het uitvoeren van vluchten.

\subsubsection{Technologieontwikkeling}

Drones bieden een platform voor allerlei payloads, van camera's tot robotarmen. Het is daarmee een inspiratie voor technologie-ontwikkelaars en mogelijk een markt voor nieuwe ideeën en oplossingen. De landbouw biedt een intrigerende hoeveelheid aan toepassingen waarmee zij aan de slag kunnen. De drone integreert een aantal technologieën die ieder op zich grote sprongen gemaakt hebben, met name in het beschikbaar komen van goedkope componenten: snelle en nauwkeurige (elektro)motoren, goedkope microsensoren (MEMS) en slimme kunstmatige intelligentie. Daarnaast zijn er voor de toepassing in diverse domeinen ook nog andere belangrijke doorbraken, zoals in de robotica, digitale optica, aerodynamica, satellietnavigatie en communicatietechnologie. Elke doorbraak in een van deze domeinen levert een nieuwe impuls op voor dronetoepassingen. Daarmee is de ontwikkeling stormachtig en onvoorspelbaar. En daarmee geeft het een grotere onzekerheid over de impact op de samenleving en daarmee hoe beleid daarmee moet omgaan. Dit geldt ook voor de beleidsterreinen landbouw en natuur waar drones ook een positieve bijdrage kunnen leveren aan maatschappelijke vraagstukken en beleidsdoelen van de overheid.

De huidige kennisagenda's voor drones worden vooral door de vliegtuig- (en ruimtevaart)instituties opgezet. Deze sectoren hebben zich bekwaamd in zorgvuldige roadmaps, waarbij de risico's in belangrijke mate worden ondervangen door uitgebreide tests en controlestappen. De luchtvaart ziet zichzelf als de meest veilige transportsector. En ook de ruimtevaart heeft weinig mogelijkheden tot ongebreidelde experimenten en is daardoor de afgelopen jaren in staat geweest tot de meest bijzondere missies en technologische hoogstandjes. De ontwikkeling van drones is bij deze sectoren echter niet noodzakelijkerwijs in de beste handen. Met name de achterliggende technologieën waar drones op gebaseerd zijn, komen voort uit domeinen waar de innovatietempo vele malen hoger ligt, zoals informatica, telecommunicatie, robotisering en geavanceerde materialen (EASA, 2016).

\subsubsection{Maatschappelijke issues}

In de rapportage aan de Tweede Kamer stelt het kabinet dat er drie belangrijke maatschappelijke issues zijn ten aanzien van de inzet van drones:

1. Luchtvaartveiligheid

2. Veiligheidsbelangen

3. Privacybelangen

Voor de landbouw en natuur zijn daar nog enkele verbijzonderingen aan toe te voegen.

\section{Bedrijfsprivacy}

De privacy wordt doorgaans begrepen als de privacy van personen. Maar door de aard van het gebruik van drones in de landbouw, namelijk als informatie-inwinningsinstrument, raakt ook de bedrijfsprivacy, met name het op deze wijze verkrijgen van data over de bedrijven, van toepassing. Door drones krijgen anderen inzicht in bedrijfsoperationele gegevens. Dit kent twee varianten: het (in opdracht) inwinnen van informatie van niet het eigen bedrijf en het hergebruik van data door de inwinnende partij of door derden op een niet vooraf bedoelde wijze. Geert Munnichs van het Rathenau Instituut doet hier onderzoek naar in relatie tot de zgn. big data en Internet of Things. Hij gaf aan in een interview dat de digitalisering van het boerenbedrijf veel kansen biedt, maar met name ten aanzien van bedrijfsprivacy nog wat haken en ogen kent. Zo zijn er ketenpartijen die met de boer 'meekijken' en via de data bijvoorbeeld een prijsvoordeel kunnen boeken. Dus een belangrijk aspect bij de inzet van drones voor monitoring van bedrijf en gewas is dat er bedrijfsoperationele teeltinformatie bij anderen terecht kan komen, zoals afnemers, leveranciers en concurrenten. De vraag hierbij is hoe 'eigendom over informatie' gedefinieerd gaat worden en hoe aantasting daarvan kan worden voorkomen dan wel aangepakt. Dit is een maatschappelijk issue dat verder rijkt dan de drones alleen, maar door de cameratechniek wel direct opspeelt. Drones maken het meer dan ooit mogelijk continu beelden te genereren op iedere plek die de piloot maar wenst. Drones maken daarom 
de discussie en besluitvorming over eigenaarschap van data en het gebruik ervan urgenter dan ooit. Mogelijk kan deze informatie leiden tot aangepast gedrag van deze partijen. Het is derhalve niet zonder meer zonder risico's.

\section{Verstoring}

Een ander aspect dat met name in de natuur geldt, is de verstoring van m.n. de fauna door het gebruik van drones. Opvliegende vogels zijn de meest herkenbare vorm daarvan. Dit speelt ook in de landbouw, maar dan in 'gewenste' vorm, zoals drones als vogelverschrikkers of om vee mee te drijven. Boswachter Thomas van der Es uit de Biesbosch geeft aan dat met name watervogels en trekvogels de meeste verstoring ervaren. In de Natura2000-gebieden is verstoring van vogels altijd verboden, maar in een park als de Biesbosch kun je niet overal bordjes neerzetten. En vaak komt de boswachter er pas achteraf achter als er filmpjes op YouTube verschijnen.

Ook recreanten zullen de aanwezigheid van drones als verstoring ervaren, net als bijvoorbeeld mountainbikes of paarden. Maatregelen kunnen ook in die parallellen gezocht worden.

\section{Regulering}

De huidige regelgeving in Nederland is gericht op risico-inperking in het luchtruim, met name in relatie tot bemande luchtvaart. De EASA werkt echter aan een raamwerk regelgeving voor Europa die in 2018 in gevoerd kan worden. Dit raamwerk gaat uit van de risico's van dronevluchten en maakt zo onderscheid in drie verschillende risicocategorieën. Dit houdt in dat operaties met een hoger risicoprofiel (bv. door gewicht, nabijheid tot mensen, privacyaspecten etc.) aan een ander (strenger) regime moeten voldoen dan vluchten met een lager risicoprofiel. Daarbij is een rol voor de droneindustrie om veiligheidsmaatregelen in de software te implementeren.

De belangrijkste spelers in de regelgeving op dit moment zijn de gevestigde luchtvaartpartijen, zoals verkeersvliegers en luchtruimautoriteiten (in Nederland het ministerie van IenM en uitvoeringsorganisatie ILenT); de belanghebbenden vanuit veiligheid en (data)privacy (met name het ministerie van $V \& J$ ) en de terreinbeheerders vanuit milieu- en hinderwetgeving.

Het Europese regelgevingsraamwerk heeft als uitgangspunt dat de uitvoering van droneoperaties gereguleerd moet worden op een wijze die proportioneel is aan de risico's van een specifieke operatie. De risico's worden doorgaans gezien in relatie tot schade aan mensen of zaken (door een crash op gebouwen, auto's etc.), tot privacyschendingen (door gebruik van foto- of filmcamera's) en in relatie tot aanvaringen in het luchtruim. In de landbouw en natuur is de kans op dergelijke risico's klein in verhouding tot de bebouwde kom. Daarom kan invoering van zo'n proportionaliteit in de regelgeving het gebruik van drones boven landbouwgrond doen toenemen. Maar dat is nog niet het geval. Een mogelijk sterk groeiend gebruik in de landbouw is de vliegende spuit of andere operatieuitvoerende drone (werkpaarddrone). Een vliegende spuit zal niet hoger dan 10-15 meter boven het gewas vliegen en lijkt daarmee meer op een doorontwikkelde hovercraft. Vliegende robots voor gewasverzorging zullen nog dichter op het gewas vliegen. Ook dit valt momenteel onder de luchtvaartwet, maar dergelijke operaties zouden als uitzondering kunnen worden aangemerkt. Ondernemer en dronebouwer Winfried Rijssenbeek wil een containment of flight envelope invoeren waarbinnen de drone op basis van zgn. geo-fencing kan opereren. Hij werkt met NLR aan in te bouwen veiligheidsmaatregelen in de software van zijn spuitdrone. Naar zijn mening is de beperkende regelgeving een reflex van de jarenlange hegemonie van de (bemande) luchtvaart in het luchtruim. Als Nederland een voorlopersrol wil spelen in dronetoepassingen, dan zal het om moeten en nieuwe regelgeving ontwerpen die wel toegerust is op intensieve benutting van het luchtruim door allerlei luchtvaartuigen.

\subsection{Maatschappelijke opgaven in innovatieopgaven omgezet}

De landbouw kent verschillende innovatieagenda's, zoals die van de topsector Agri \& Food en de topsector Tuinbouw \& Uitgangsmaterialen. Daarnaast is in 2016 de cross-over roadmap "High Tech to Feed the World" (HT2FTW) ontstaan. In deze innovatieagenda's zijn maatschappelijke vraagstukken verweven met de economische belangen van bedrijven. De volgende innovatieopgaven bieden uitdagingen voor drones: 
- Verbeteren resource use efficiency: "Twee keer meer met twee keer minder"12;

- Weerbaarheid teelt- en bedrijfssystemen;

- Precisielandbouw;

- Beheersen emissies pesticiden en N/mineralen;

- Kringlopen;

- Duurzaam bodembeheer.

Daarnaast biedt de roadmap HT2FTW goede aanknopingspunten om de ontwikkeling en toepassing van drones verder te stimuleren. Uit deze roadmap:

De open teelt met haar monoculturen is bij uitstek gevoelig voor ziektes en plagen. In de traditionele landbouw worden bestrijdingsmiddelen gebruikt om die tegen te gaan. In de biologische landbouw is dit niet toegestaan en is het van levensbelang dat problemen vroegtijdig worden gedetecteerd om mechanisch actie te kunnen ondernemen. De resolutie van satellietbeelden is nog onvoldoende om dit te realiseren. Bovendien vraagt het doorgaans om een multispectrale analyse die door wolken wordt verstoord. Vision systemen op rijdende of vliegende platforms bieden voor de korte en middellange termijn aanvullende mogelijkheden.

Om hier invulling aan te geven, kunnen innovaties ontstaan, zoals:

- Drones voor het monitoren van gewassen, liefst zo veel mogelijk autonoom;

- Drones voor het bespuiten van gewassen;

- Drones voor het plukken/selecteren van oogstrijpe producten;

- Drones voor het vervoeren van hoogwaardige zaken als chemicaliën/medicijnen, sperma, onderdelen etc.

Waar het gaat om het toepassen van camerasystemen voor optimale(re) mesttoediening, is het van belang om de relatie tussen reflectiewaarden en concrete bemestingsinstructie verder uit te werken en te verifiëren. Dit wordt opgepakt in de PPS "op naar Precisielandbouw 2.0" in de Agri \& Food topsector. Dit vertalen in handelingsperspectief is door experts als een van de grote knelpunten genoemd in het gebruik van Remote Sensing in het algemeen, maar ook drones in het bijzonder. Waar het gaat om spuiten, is de uitdaging om drones te ontwikkelen die een heel veld kunnen spuiten zonder bij te laden en om binnen de milieueisen te blijven (m.n. drift). Ondernemer Winfried Rijssenbeek van Drone4Agro is samen met een aantal industriële partners en universiteiten (WUR en UT) bezig met de ontwikkeling van een commerciële spuitdrone en werkpaarddrone, die 50 ha per dag automatisch kan behandelen. Deze drone werkt met een docking station van waaruit snellading en middel opgezogen wordt. De drone heeft stille propellers en is 24/7 inzetbaar. Het ontlast de boer in de piekperiode in de zomer. De drone moet ingezet kunnen worden zoals de spuitmachine nu, aldus Rijssenbeek.

\footnotetext{
${ }^{12}$ Titel van verslag door H. van Gurp (PPL) over symposium "Precisielandbouw verhoogt de opbrengst" in 2011
} 


\section{Discussie}

De wijze waarop drones en het gebruik daarvan zich ontwikkelen is te duiden als een sleuteltechnologie: een technologie die versnelling teweeg kan brengen in vele verschillende onderzoeks- en toepassingsgebieden, terwijl de maatschappelijke consequenties die ermee gepaard gaan nog deels uitgezocht moeten worden ${ }^{13}$ en waarover de wet- en regelgeving nog volop in ontwikkeling is.

Opkomende ICT-instrumenten en hightechsystemen, waaronder ook de drones gerekend worden, zorgen voor nieuwe of verbeterde manieren om data over het agrarische productieproces te verzamelen. Wetenschappelijk bewijs over hoe deze nieuwe databronnen de landbouw helpen met verhoogde efficiëntie en verminderde milieudruk neemt toe. Het gebruik in de landbouw wordt aangemoedigd door de voortdurende vernieuwing in de dronetechnologie die zorgt voor kleinere, goedkopere systemen. De prijs van informatie gaat daarmee omlaag. Er heerst opwinding in de landbouw over het potentieel van drones, alhoewel nu voornamelijk Remote Sensing wordt aangeboden als commerciële dienst (met potentiële markten voor bespuitingen en vogelverschrikkers o.a.). Het gebruik van drones als sensor zal exponentieel toenemen alsook de vertaling van sensorwaarden naar operationele kennis doorontwikkeld wordt. Dit is cruciaal voor het creëren van toegevoegde waarde en een zaak waar meer sensorsystemen mee kampen. Het gebruik van data door boeren vereist nieuwe strategieën, waarbij rekening gehouden wordt met de individuele behoeften, mogelijkheden en beperkingen van boeren. De toepassing ICT en big data in de landbouw trekt nieuwe partijen aan met verdienmodellen die de huidige waardeketen passeren, zoals we ook al gezien hebben in andere domeinen zoals door Airbnb en Uber. Zonder aanpassingen zullen huidige verdienmodellen traditioneel of zelfs overbodig worden. Hier ligt een maatschappelijke vraag over de mate waarin deze ontwikkelingen aanmoediging dan wel regulering vereisen ${ }^{14}$.

Drones vertegenwoordigen een weelde aan nieuwe ICT gedreven technologieën die uiteindelijk de landbouwproductie zullen veranderen. De vele diverse artikelen in de media laten de vele gezichten van drones zien waarmee de jonge en opkomende technologie te maken heeft. Dit vraagt om geïntegreerde beleidsvorming, zoals momenteel ook in Nederland plaatsvindt door bijdragen van de betrokken departementen. Beleid en regelgeving zijn wellicht sleutels om de positieve bijdrage aan landbouwproductie te balanceren met de maatschappelijke zorgen rondom veiligheid, (data)privacy en verstoringen in de natuur.

Drones dragen bij aan de ontwikkeling van Smart Farming: de inzet van ICT, robottechnologie en besluitvormings-ondersteunende systemen waarmee de boer slimmere, beter geïnformeerde (evidence based) beslissingen kan nemen. Een belangrijk aspect daarbij is een goede informatievoorziening, en drones uitgerust met camera's en sensoren kunnen dat (deels) invullen. Belangrijke beleidsthema's als het verhogen van de resource efficiency of het verminderen van emissies hebben baat bij de inzet van drones voor Smart Farming. De in dit rapport genoemde voorbeelden bieden vele mogelijkheden hiervoor. Stimulering van drones in de landbouw kan voor het beleidsterrein Landbouw, maar ook voor Natuur, Milieu en Klimaat, derhalve veel opleveren.

De tweede belangrijke bijdrage van drones ligt in de bodemverbetering. Drones die als een hovercraft over het gewas vliegen en werktuigen dragen die bewerkingen uitvoeren die anders door rijdende tractoren worden gedaan, hebben een zeer positieve invloed om het voorkomen van bodemverdichting. Verdichting of compactie, m.n. door steeds grotere en zwaardere machines, heeft een negatieve invloed op de landbouwopbrengst, maar ook op waterdoorlatendheid, nutriëntenbeschikbaarheid, bodemleven etc. Stimulering van het gebruik van drones, in dit geval megadrones met een draagkracht van $100 \mathrm{~kg}$ of meer, heeft dus een positief effect op de bodem en biedt voordelen voor beleidsterreinen als bodem, water en landbouwproductie.

\footnotetext{
13 Maclaine Pont, P., R. van Est, J. Deuten (2015). Met beleid vormgeven aan socio-technische innovatie. Den Haag: Rathenau Instituut.

14 Paragraaf gebaseerd op Wal, T. van der, L. Kooistra en K. Poppe (2015) The role of new data sources in Greening Growth - the case of Drones. Issue Paper for the 2015 OECD Green Growth and Sustainable Development Forum.
} 
Kortom, deze nieuwe technologie biedt mogelijkheden om maatschappelijke vraagstukken en beleidsdoelen van de overheid te dienen, terwijl nog weinig bekend is over de maatschappelijke consequenties van het toepassen ervan, zoals op het punt van fysieke risico's (crashes etc.), dataprivacy, overlast (ook op bijvoorbeeld weidevogels).

Een interessant aspect van de dronesontwikkeling als technologisch innovatiesysteem is het feit dat zich als vanzelf een diversiteit aan technologische oplossingen ontwikkelt. Deze diversiteit voorkomt lock-in van suboptimale alternatieven en het maakt meerdere combinaties mogelijk, waardoor de weerbaarheid van een opkomende technologie tegen veranderende omstandigheden wordt verhoogd ${ }^{15}$. Het is een handvat voor beleid om met beschikbare beleidsinstrumenten deze diversiteit in stand te houden om daarmee de ontwikkeling van drones verder te helpen.

Drones zullen in de nabije toekomst een onvermijdelijk onderdeel van ons dagelijks leven worden. Wellicht op manieren die we nu nog niet voorzien, maar in ieder geval is het een technologische ontwikkeling die vele mogelijkheden biedt. Zoals in deze verkenning geschetst, zijn er tal van toepassingen denkbaar en al gerealiseerd. In de landbouw resoneert vooral het enthousiasme. Tot nu toe zijn de maatschappelijke consequenties onvoldoende in beeld gebracht. Een aantal van deze consequenties zullen we ook pas achteraf goed begrijpen. Toch zijn er al zaken die nu al om aandacht vragen. Voor de landbouw geldt met name de veiligheid van bedrijfsinformatie als een grote uitdaging, omdat het wel duidelijk wordt dat de inzet van drones en de verwerking van data niet alleen op het boerenbedrijf kan gebeuren, maar zich al gauw naar 'de cloud' verplaatst. Ook ethische vragen gerelateerd aan robotisering en informatisering van onze voedselproductie zijn van belang, maar worden in discussies niet of nauwelijks aangeroerd.

Wat ongewild in deze verkenning, in de sector en in het maatschappelijk debat de boventoon voert, is de wet- en regelgeving rondom de inzet van drones in ons luchtruim. De overheid heeft grote terughoudendheid en gering adaptief vermogen getoond om deze nieuwe technologie in adequate regelgeving te vertalen. De invalshoek vanuit luchtverkeersveiligheid enerzijds, en persoonlijke veiligheid en privacy anderzijds leveren aanzienlijke barrières op voor het breed gebruik van drones. De overheid neemt daarbij ook onvoldoende deel in het innovatiedebat, anders dan als regelgever of handhaver.

Het is evident dat veiligheid van groot belang is en dat de drone-industrie, de gebruikers en anderen zich nog meer bewust moeten zijn van de complexiteit en dynamiek die met de inzet van drones gepaard gaat. Een breed debat over kansen, mogelijkheden en randvoorwaarden moet gevoerd worden en de overheid is de partij bij uitstek om dat debat te organiseren. Het is van belang dat hierbij zo veel mogelijk evidence based gewerkt wordt. Er is daarom een grote behoefte aan een living lab waar ondernemers, gebruikers, handhavers etc. experimenteren met drones om (on)mogelijkheden beter te duiden. Rondom zo'n living lab kunnen netwerken ontstaan waarin het debat gevoerd wordt.

${ }^{15}$ van Rijnsoever, F. J., van den Berg, J., Koch, J., \& Hekkert, M. P. (2015). Smart innovation policy: How network position and project composition affect the diversity of an emerging technology. Research Policy, 44(5), 1094-1107. 


\section{$5 \quad$ Conclusies en aanbevelingen}

\section{Wat is de technologische ontwikkeling van drones en hoe is die tot stand gekomen?}

Zoals beschreven in dit rapport is de technologische ontwikkeling van drones buiten de landbouw ontstaan. De landbouw wordt echter als een belangrijke afzetmarkt gezien, zo niet de belangrijkste. Haast alle dronebouwers noemen landbouw bij hun toepassingen. In dit rapport is aangegeven dat de drone wellicht de missing link is voor de verdere ontwikkeling in de precisielandbouw, omdat het de mogelijkheid biedt om actuele sturingsinformatie voor de akkerbouwer te leveren.

Een interessante constatering van EASA is dat het meeste onderzoek aan drones door traditionele luchtvaart partijen wordt uitgevoerd die zich ook identificeren met de luchtvaartpraktijk en regelgeving. Hierdoor krijgen innovaties uit sectoren met een sneller innovatietempo (zoals ook de landbouw) minder ruimte. De onderzoeksprogrammering van droneonderzoek, de kennisagenda's en dergelijke, worden door spelers uit de luchtvaartsector opgesteld, hetgeen leidt tot drempels voor nieuwe, sectorvreemde bedrijven en meer kansen voor de usual suspects.

De ICT-sector met name heeft wel meer invloed op de technologische ontwikkeling in de payloads, en die gaat dan ook vele malen sneller. Met name camerasystemen, die steeds kleiner, energiezuiniger en functioneel rijker worden. Naast gewone camera's is er een enorme ontwikkeling in multi- en hyperspectrale camera's, thermische camera's, radar en LiDAR-systemen voor drones etc. Voor de landbouw zijn deze camera's alle relevant voor verschillende toepassingen.

Een andere vorm van payload zijn de landbouwspuiten of robotarmen om fruitbomen te snoeien. De robotica heeft een enorme potentie, maar de combinatie met drones is hierin nog nauwelijks verkend. Autonome, vliegende robots die de gewasverzorging grotendeels overnemen, is een mooi toekomstbeeld.

De technologische ontwikkeling is gebaat bij interesse vanuit de computerindustrie die in de drones een nieuwe afzetmarkt ziet voor hoogwaardige computerchips. Hierdoor wordt de elektronica sneller, kleiner, zuiniger, robuuster etc., allemaal aspecten waar de drone als geïntegreerd platform baat bij heeft.

\section{Welke kansen bieden drones voor landbouw en natuur?}

Alhoewel de ontwikkeling en toepassing van drones voor velen nog heel nieuw is en men de mogelijkheden aftast, zijn de contouren van relevante innovaties zichtbaar. Innovaties die prima passen bij de drijfveren van de agrosectoren (efficiënter produceren) en maatschappelijke uitdagingen (minder emissies/vervuiling, grotere bodemvruchtbaarheid, minder verspilling). Uitdagingen die ook al reeds zaten in ontwikkelingen rond precisielandbouw.

Alleen al de drone als vliegende camera biedt een veelvoud aan innovaties. Voor de landbouw is de meest in het oog springende innovatie om met drones taakkaarten voor precisielandbouw te maken, voor plaats-specifieke (of plant-specifieke) verzorging van gewassen. De drone concurreert hierin met satellieten, tractor-gedragen sensoren en softwaresystemen die managementzones maken uit historische gegevens.

Spuitdrones, als innovatie op de bemande landbouwluchtvaart, is een innovatie die vooral van pas komt bij moeilijk bereikbare akkers en velden, zoals de steile hellingen in de Moezel en de rijstvelden in Japan. Voor Nederland biedt de spuitdrone met name een alternatief voor zware machines door het vermijden van bodemverdichting.

Zoals geschetst in hoofdstuk 2 zullen innovaties eerst bestaande werkwijzen beter maken (sneller, efficiënter etc.) om vervolgens te leiden tot nieuwe businessmodellen, nieuwe diensten en werkwijzen. Net als gps zorgt voor andere manieren van logistiek bij de uitvoering van landbouwproductie, zal de drone eerdaags ook een dergelijke doorbraak bereiken.

In de natuur hebben de afgelopen jaren met name de natuurfilms profijt gehad van de drones. Daarnaast zijn natuurlijk de monitoringsmogelijkheden uit de landbouw zonder meer ook in de natuur toepasbaar. In natuurparken worden drones inmiddels ook ingezet voor verkenning en detectie van bosbranden of stropers dan wel eenvoudigweg voor het tellen van bezoekers. 


\section{Welke maatschappelijke consequenties brengt deze technologie met zich mee?}

De drone als data-inwinner in de big data-gedachte heeft wellicht een aantal consequenties waar rekening gehouden moeten worden. De dataprivacy is wellicht het belangrijkst en heeft ook de aandacht van gebruikers: wat gebeurt er met de data van mijn velden en wie heeft er toegang toe/zeggenschap over. Een simplistische stelling als 'de boer blijft eigenaar van zijn gegevens' is niet houdbaar en wordt ook niet altijd gevolgd.

Een andere consequentie - die we overigens uitlokken - is een sterke opgang van precisielandbouw en daarmee van data-gedreven landbouw. Hiermee ontstaat een nieuwe boer die zijn bedrijfsvoering in hoge mate uitvoert met ICT. Dit heeft gewenste effecten in aspecten als hogere efficiëntie en lagere milieudruk, maar het neigt ook naar grootschaligere, intensievere landbouw, hetgeen in het maatschappelijk debat nogal eens negatief gepresenteerd wordt.

\section{Hoe beïnvloedt deze ontwikkeling het beleid? Hoe zou de overheid moeten reageren?}

Het beleid wordt op meerdere manieren beïnvloed. Ten eerste zijn de drones bijna niet meer weg te denken en zal beleid gevormd moeten worden om het gebruik van drones in goede banen te leiden. De huidige luchtvaartwet- en -regelgeving biedt genoeg mogelijkheden om waar nodig maatregelen te treffen, zoals in natuurgebieden of boven andermans land. Maar aanpassingen kunnen de ontwikkeling helpen, met name de invoering van een vluchtgerichte aanpak waarbij de risico's van een vlucht belangrijk zijn.

Ten tweede worden door de ontwikkelingen met drones allerlei kansen voor de overheid en haar beleidsdoelen zichtbaar, zoals het optimaliseren van de productie (profit) met zo min mogelijk negatieve (milieu)effecten (planet). Drones kunnen substantieel bijdragen aan deze ontwikkelingen. Tot nu toe heeft de overheid al jaren bijgedragen aan het onderzoek naar precisielandbouw. De drijfveren daartoe waren vooral de economische positie van de boer. Pas in beperkte mate wordt vanuit de Nederlandse en Europese overheid gekeken naar precisielandbouw als middel om andere doelen (milieu, klimaat, leefbaarheid, dierenwelzijn etc.) haalbaarder te maken. Ook in de huidige Publiek-Private Samenwerkingsprojecten in de agrofoodtopsector staan de economische aspecten voorop, echter vele kostenbesparingen hebben tegelijkertijd een positief milieueffect, zoals minder mest, minder gewasbeschermingsmiddelen, minder watergebruik, minder diesel etc.

Ten derde zijn er op het gebied van bepaalde maatschappelijke consequenties, zoals onduidelijkheid over de eigendom van data, privacy en mogelijke andere zaken, nog geen afdoende maatregelen getroffen of afspraken gemaakt. Hierdoor ontstaat de kans dat de verdere toepassing van drones in agro en natuur stagneert, waardoor ook kansen voor maatschappelijke vraagstukken niet benut gaan worden.

Big data heeft de aandacht van de multinationals en daarmee laadt het ook de verdenking op zich dat hiermee de belangen van de boer ondergeschikt zijn. En dat is niet geheel onterecht. Er zijn echter wel degelijk win-winaspecten in te vinden. Machinefabrikanten verzamelen anonieme informatie over de prestatie van hun machines en werktuigen - parallel aan onder andere de auto-industrie- die zij inzetten voor verbeteringen en dienstverlening. Daar heeft de boer dus baat bij. Het is echter voor niemand duidelijk hoe goed dat soort data afgeschermd zijn en of deze ook niet voor andere doeleinden gebruikt worden. Om de parallel met de auto-industrie nog even te gebruiken: de wijze waarop Volkswagen in het nieuws kwam met software is natuurlijk ook geen maatschappelijk wenselijk beeld. De discussie over big data is waarschijnlijk een van de meest wezenlijke, waar ook het gebruik van drones mee samenhangt.

De ontwikkeling van drones voor landbouwdoeleinden verloopt - zoals zo veel technologische innovaties - het typische pad langs de zgn. "Valley of Death" (Randolph Beard et al., 2009): een periode nadat een inventie succesvol is gebleken, maar breder gebruik nog gehinderd wordt door operationele barrières en als gevolg daarvan door onvoldoende funding. Deze Valley of Death is vernoemd naar het aantal initiatieven en start-ups die in deze fase sneuvelen door onvoldoende uithoudingsvermogen (m.n. financieel). De overheid kan innovaties in deze fase ondersteunen met bijvoorbeeld launching customership of in het coördineren/organiseren van demonstraties en grootschalige pilots. Het eerder genoemde FieldLab is hier een goed voorbeeld van. Het ontbreekt ondernemers en afnemers aan een georganiseerde experimenteerruimte waar de meerwaarde getoond kan worden en ook operationele aspecten doorontwikkeld kunnen worden. 


\subsection{Aanbevelingen}

Met de verwachting dat landbouw de belangrijkste afzetmarkt van drones wordt, het feit dat Nederlandse universiteiten, onderzoeksinstellingen, bedrijven en start-ups hard aan innovaties werken, het feit dat Nederland een landbouwgrootmacht is en de Nederlandse landbouwsector graag vooroploopt in toepassing van innovatieve technieken, pleit ervoor dat EZ meer aandacht geeft aan de ontwikkeling van drones als onderdeel van het technologische complex van de precisielandbouw: de behoefte aan informatie voor verbeterde bedrijfsvoering en efficiëntere activiteiten is erg hoog en drones vormen zoals gesteld een missing link waarbij de juiste informatie kan worden gegenereerd. Landbouw is een interessant toepassingsgebied voor drones en het is een mogelijkheid voor EZ om meer droneonderzoekers in contact te brengen met boeren of landbouworganisaties om verder te kijken dan alleen het beter maken van de informatie-inwinning. Een belangrijk aspect hierbij is de inrichting van een living lab (zie verder) en daaromheen de maatschappelijke discussie entameren over nut, noodzaak, kansen en uitdagingen. Daarnaast kan EZ een belangrijke tegenkracht vormen binnen de overheid waar het de ontwikkeling van de regelgeving betreft. Niemand twijfelt aan de noodzaak van regels, maar ondernemers voelen zich onnodig beknot en op hoge kosten gejaagd door het huidige beslag in wet- en regelgeving.

Het is vanuit die gedachte van belang om de regels voor het vliegen in landbouwgebied zo simpel en laagdrempelig mogelijk te maken - conform het Europese kader dat uitgaat van het risicoprofiel van de operaties. In vergelijking met de stad zijn die in de landbouw substantieel lager. EZ zou een grotere rol kunnen claimen in de vormgeving van deze luchtvaartregels.

De overheid kan meer bewijs zoeken of leveren dat precisielandbouw een middel is om andere doelen (milieu, klimaat, leefbaarheid, dierenwelzijn etc.) haalbaarder te maken. Dit aspect kan nog verder uitgebouwd worden, vooral door bijvoorbeeld de precisielandbouw als vergroeningsmaatregel aan te merken in het Europese landbouwbeleid of in eigen land stimulering van precisielandbouw te koppelen aan milieu- en klimaatdoelen.

Voor de snelle uptake in Nederland is het goed om bijvoorbeeld experimenteerruimte voor drones in te richten, bijvoorbeeld als Living Lab. Dit is met name gericht om nader te verkennen of de beloftes van deze nieuwe technologie uitkomen, zowel richting leveranciers, afnemers, overheid als andere belanghebbenden. Voor de overheid biedt dit bovendien de mogelijkheid om de bijdrage/meerwaarde van drones voor het aanpakken maatschappelijke vraagstukken/beleidsdoelstellingen nader te onderzoeken. Tevens zou in zo'n experimenteeromgeving meer duidelijkheid kunnen ontstaan over de maatschappelijke consequenties en hoe daarmee om te gaan.

$\mathrm{Er}$ is al zo'n dronezone ingericht (NLR in de Noordoostpolder) voor het testen van drones zelf als toestel, maar voor landbouwdoeleinden moet een substantieel gebied met landbouw worden gealloceerd. Dit living lab kan een grote aantrekkingskracht hebben op droneontwikkelaars en kan wereldwijd de mogelijkheden tonen. Eenzelfde pleidooi moet uiteraard ook voor de natuur gehouden worden. Ook daar kan een experimenteerruimte een versnelling van de zichtbaarheid van impact mogelijk maken.

De maatschappelijke consequenties van het gebruik van drones zijn nog niet scherp. Er moet echter een constructief debat gevoerd gaan worden tussen belanghebbenden om verschillende scenario's te verkennen en daarop te acteren. Het is niet eenvoudig om dit zorgvuldig te doen en dit vereist dan ook goede facilitatie. Dit koppelen aan een living lab is van grote meerwaarde. Maar ook over de grens kijken naar wat en hoe andere landen hierin ondernemen is van belang. 


\section{Referenties}

Een aantal referenties staat als voetnoten in de tekst. Daarnaast zijn deze bronnen gebruikt:

EASA, 2015 (a). Introduction of a regulatory framework for the operation of unmanned aircraft. European Aviation Safety Agency, Technical Opinion, https://www.easa.europa.eu/opinions.

EASA, 2015 (b). https://www.easa.europa.eu/easa-and-you/civil-drones-rpas (last visited 21-MAY-2016).

EASA, 2015 (c). A risk based approach to regulation of unmanned aircraft, https://www.easa.europa.eu/system/files/dfu/204696_EASA_concept_drone_brochure_web.pdf.

EASA, 2016. Roadmap for Drone Operations in the European Union - The roll-out of the EU operation centric approach. Non-paper, besproken op de RPAS stakeholders workshop in Keulen, 20 juni 2016.

Gaddis, 2014. Drones: The revolution will be commoditized. Ben Gaddis, Innovation Insights blog posts, May 2014

http://insights.wired.com/profiles/blogs/drones-the-revolution-will-be-commoditized (last visited 16-AUG-2016).

Joziasse P. en L. Op de Beek. Drones, verkenning voor de natuur, Innovatie Agro \& Natuur, april 2016. http://www.innovatieagroennatuur.nl/nl/bibliotheek/rapporten/647/Dronesverkenningvoordenatuur.

Lerink, P., 2015. 50 tinten groen, Geo Info 2015-2, pp 22-25. https://www.geo-info.nl/sites/nl.geo-info.www/files/documents/Geo-Info\%202-2015\%20def.pdf.

Proplanta, 2015. Pflanzenschutz-Drohnen weiterhin in Weinbergen unterwegs, Proplanta, september 2015, http://www.proplanta.de/Agrar-Nachrichten/Pflanze/Pflanzenschutz-Drohnen-weiterhin-inWeinbergen-unterwegs_article1442249205.html.

T Randolph Beard, T., G.S. Ford, T.M. Koutsky en L.J. Spiwak, 2009. A Valley of Death in the innovation sequence: an economic investigation. Research Evaluation (18/5), Pp.343-356.

Wal, T. van der, B. Abma en A. Nagelhout, 2014. Stakeholder Analysis GNSS in Agriculture, UNIFARM project, January 2014. http://project-unifarm.eu/LinkClick.aspx?fileticket=oKIK9o4BZNg\%3d\&portalid=5.

WODC, 2015. Het gebruik van drones - Een verkennend onderzoek naar onbemande luchtvaartuigen, B.H.M. Custers, J.J. Oerlemans en S.J. Vergouw. WODC-rapport 313. http://www.wodc.nl/onderzoeksdatabase/2518-gebruik-van-drones.aspx.

Wall Street Journal, 2013. The Flight of 'Drone' From Bees to Planes. B. Zimmer, July 26, 2013, The Wall Street Journal, http://www.wsj.com/articles/SB10001424127887324110404578625803736954968 (last visited 21 MAY 2016).

UAVSI, 2013. the economic impact of unmanned aircraft systems integration in the United States, March 2013, Association for Unmanned Vehicle Systems International.

http://www.auvsi.org/auvsiresources/economicreport. 
Alterra Wageningen UR

\section{Postbus 47}

6700 AA Wageningen

T 0317480700

www.wageningenUR.nl/alterra

Alterra-rapport 2742

ISSN 1566-7197
Alterra Wageningen UR is hét kennisinstituut voor de groene leefomgeving en bundelt een grote hoeveelheid expertise op het gebied van de groene ruimte en het duurzaam maatschappelijk gebruik ervan: kennis van water, natuur, bos, milieu, bodem, landschap, klimaat, landgebruik, recreatie etc.

De missie van Wageningen UR (University \& Research centre) is 'To explore the potential of nature to improve the quality of life'. Binnen Wageningen UR bundelen 9 gespecialiseerde onderzoeksinstituten van stichting DLO en Wageningen University hun krachten om bij te dragen aan de oplossing van belangrijke vragen in het domein van gezonde voeding en leefomgeving. Met ongeveer 30 vestigingen, 6.000 medewerkers en 9.000 studenten behoort Wageningen UR wereldwijd tot de aansprekende kennisinstellingen binnen haar domein. De integrale benadering van de vraagstukken en de samenwerking tussen verschillende disciplines vormen het hart van de unieke Wageningen aanpak. 



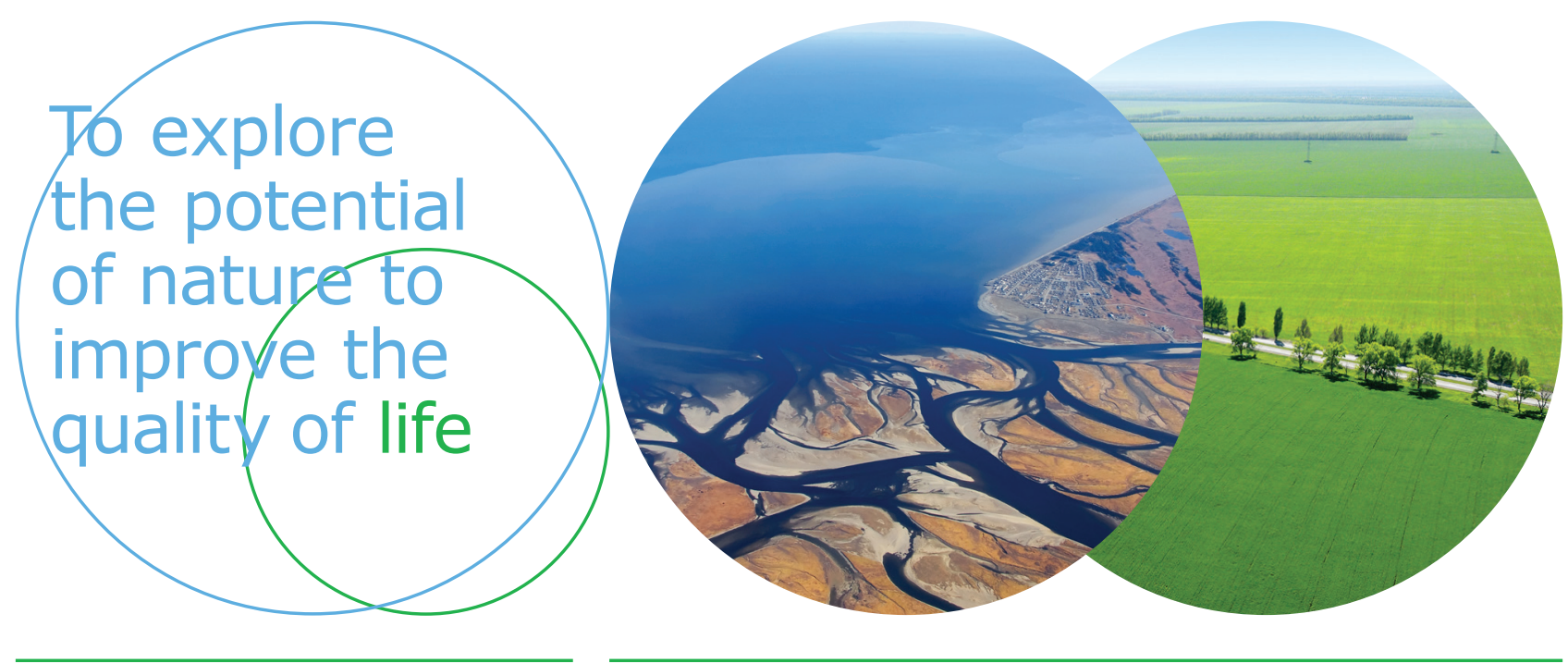

Wageningen Environmental Research Postbus 47

$6700 \mathrm{AB}$ Wageningen

T 317480700

www.wur.nl/environmental-research

Rapport 2742

ISSN 1566-7197
De missie van Wageningen University \& Research is 'To explore the potential of nature to improve the quality of life'. Binnen Wageningen University \& Research bundelen Wageningen University en gespecialiseerde onderzoeksinstituten van Stichting Wageningen Research hun krachten om bij te dragen aan de oplossing van belangrijke vragen in het domein van gezonde voeding en leefomgeving. Met ongeveer 30 vestigingen, 5.000 medewerkers en 10.000 studenten behoort Wageningen University \& Research wereldwijd tot de aansprekende kennisinstellingen binnen haar domein. De integrale benadering van de vraagstukken en de samenwerking tussen verschillende disciplines vormen het hart van de unieke Wageningen aanpak. 